Historic, Archive Document

Do not assume content reflects current scientific knowledge, policies, or practices. 
1 


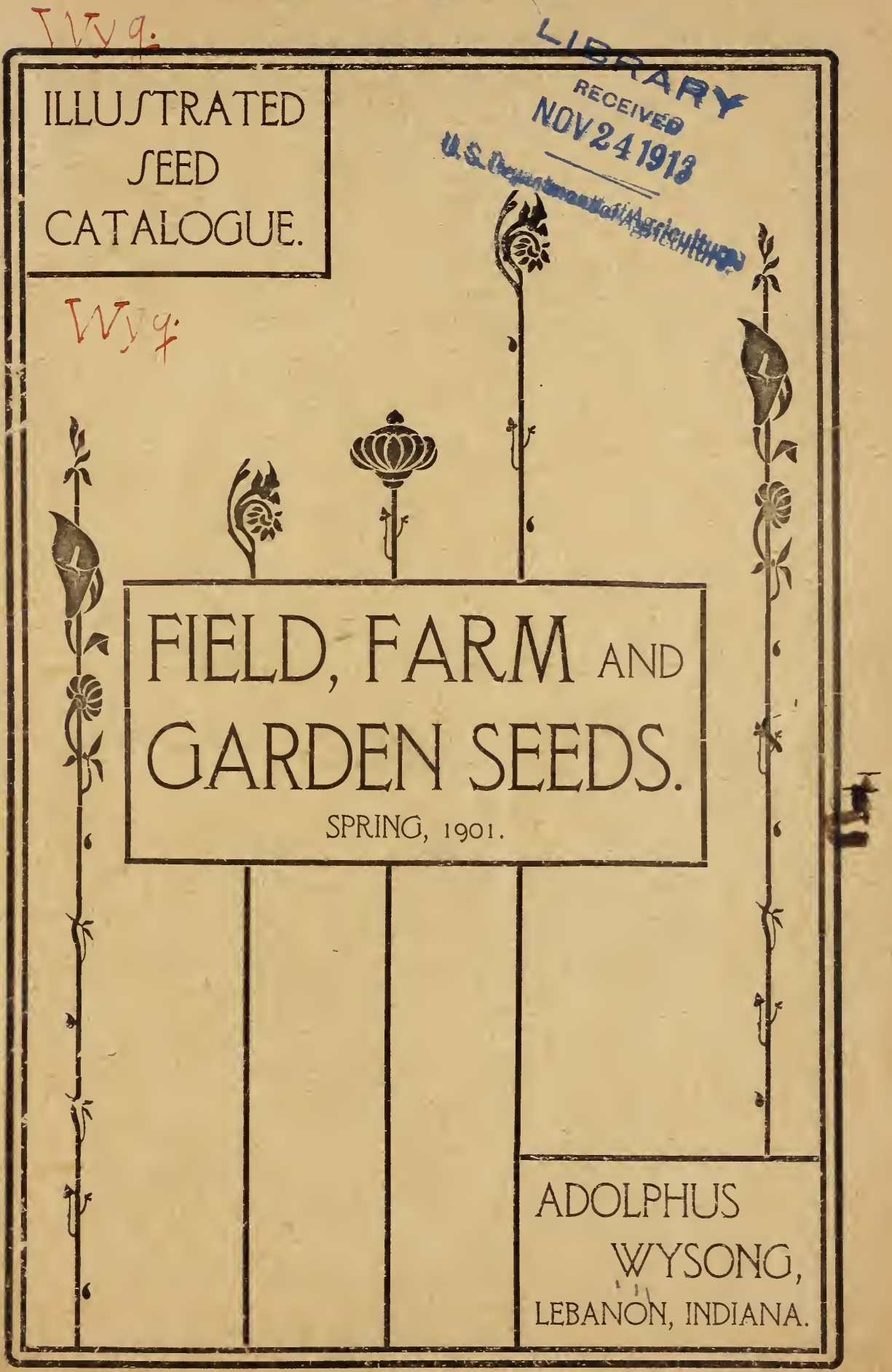




\section{THE LITTLE GIANT SEEDER.}

No. 3. $\$ 1.75$.

This is the best and cheapest crank seeder made in the quality of work done and durability.

The gearing is rigid, being in an iron frame. It will not get out of order nor be affected by dampness of the weather.

The agitator, or force feed, is such that the Little Giant does not require seed to be cleaned, and will sow orchard or blue grass.

It will distribute all kinds of Fertilizer, Land Plaster and Ashes. Flax and Clover Seed thirty-six feet to the

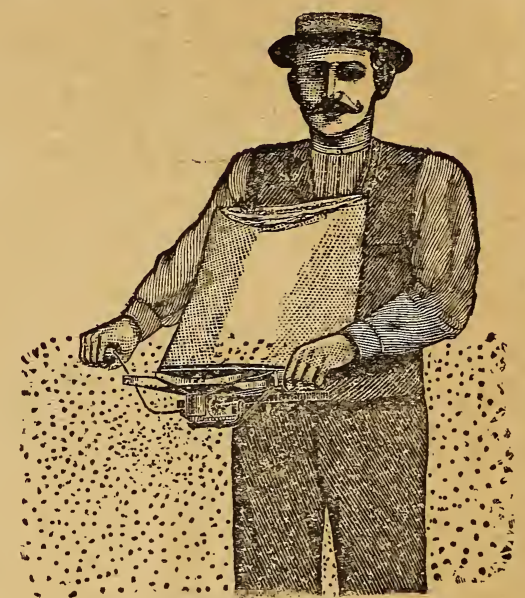
IITTILE GIAN'T No, 3 . round; Wheat fifty feet to the round; Buckwheat forty-six feet to the round; Barley forty feet to the round; Timothy Seed twenty-seven feet to the round; Oats thirty-six feet to the round.

Don't Pay $\$ 5$ for a Seeder When You Can Get Its Better for Less Money.

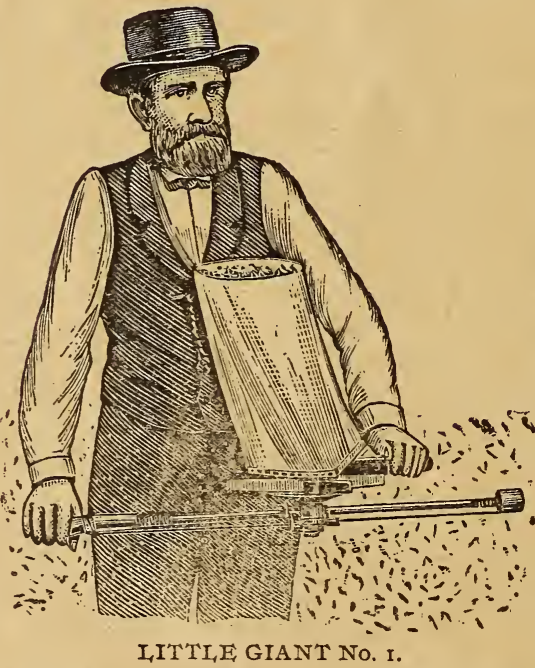

No. 1. \$1.25.

This Seeder, when first invented, sold for \$15.00.

This Seeder has a steel Bow, swinging movement, and malleable cast iron brace, being the only Seeder made having an iron frame, force feed and pressed distributing wheel, hand hold on the side and no feed plate to carry. See it and you will be convinced. No farmer who has used one would do without it for five times its cost. Has no equal.

SEE IT.

EXAMINE IT.

TRY IT. 


\section{$-$ \\ orfice or \\ ADOLPHUS WYSONG,}

\section{LEBANON, IND.}

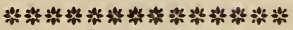

\section{To OUR FRIENDS AND CUSTOMERS:}

In presenting to you our aunual Catalogue and Price List for I90I, we take pleasure in thanking you for the liberal patronage you have given us, and respectfully ask for of a continuance of the same for the future.

Nothing for which money is expended makes so large returns as Seeds, if they are GOOD. Nothing causes greater vexation than WORTHLESS seeds. If you want to avoid disappointment, don't rely on seeds peddled over the country and sold on commission-the chances are against their vegetating. We send out no seeds on commission.

The illustrations and descriptions are as near right as they can be made. Our prices will be found low.

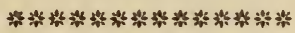

\section{INSTRUCTIONS TO PURCHASERS.}

Terms of Sale.-Cash must be sent with the order. This may be done either in the form of a Money Order, Bank Draft, Express Order, Registerd Letter, or cash may be sent by express. Postage stamps received same as cash. Remittances in any other way are entirely at sender's risk.

When to Order. - We are ready to fill your order as soon as this Catalogue reaches you, so please order early.

About Forwarding.-Every order is executed at once upon its receipt, or a reason given why it has not been sent, so that parties ordering may know that if goods are not received in proper time, it is almost certain that the letter has not been received by us.

Seeds are Guaranteed to arrive safe and in good condition, due care having been given to observe faithfully the previous and following suggestions, in all cases where the order is covered by the necessary remittances.

We Pay Postage and Expressage, except where noted otherwise, on all seeds ordered by the packet, ounce or pound, pint or quart, but positively not by peck or bushel.

Name and Addrass should be written as plainly as possible, and care exercised to have place of residence, county and state in full, giving all shipping directions. Yours Truly,

\section{ADOLPHUS WYSONG.}

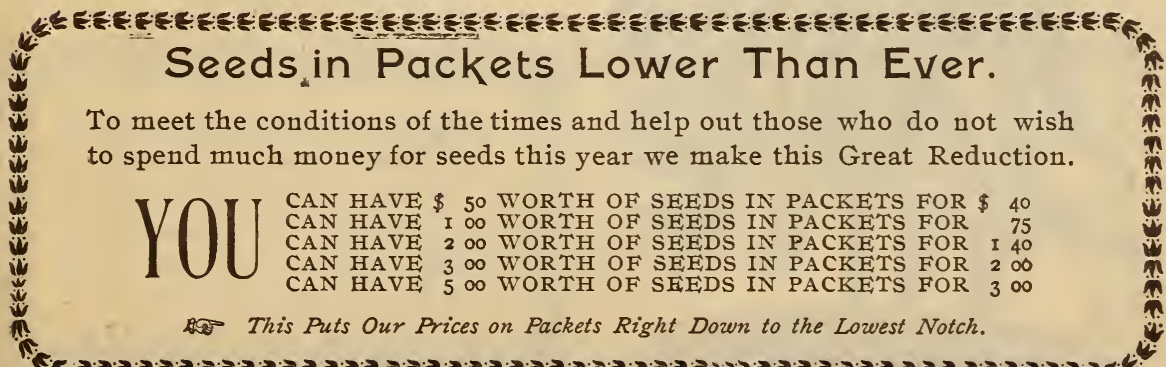




\section{BEANS, Wax Pod Varieties,}

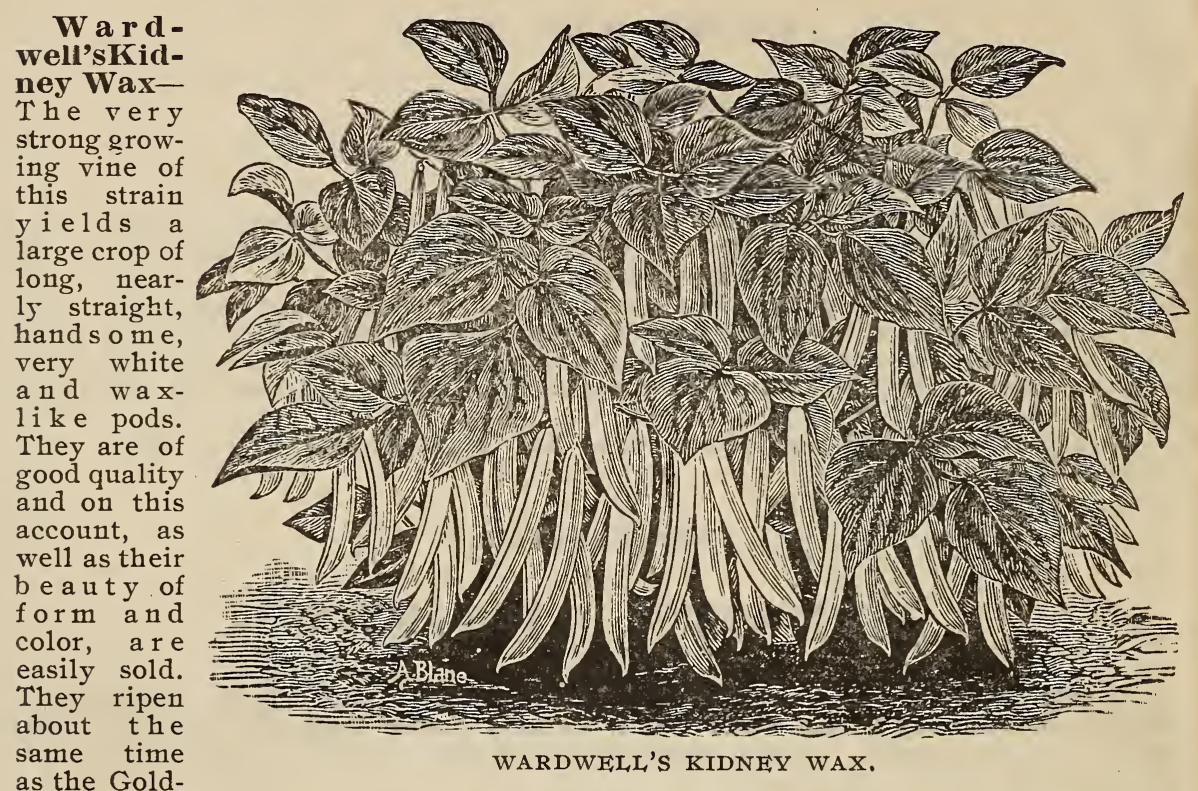

as the Gold-

en Wax. The dry beans are large, kidney shaped, white, with dark markings around the eyes. Pkt. $5 \mathrm{c}$; $1 / 2$ pint Ioc; pint 20c; quart $35 \mathrm{c}$.

Improved Golden Wax-This variety possesses all the good qualities of the old Golden Wax, but is larger in pod and much more prolific. Excellent quality, tender, melting flavor at all stages of growth. Pkt. 5 c; $1 / 2$ pint Ioc; pint $20 \mathrm{c}$; quart $35 \mathrm{c}$.

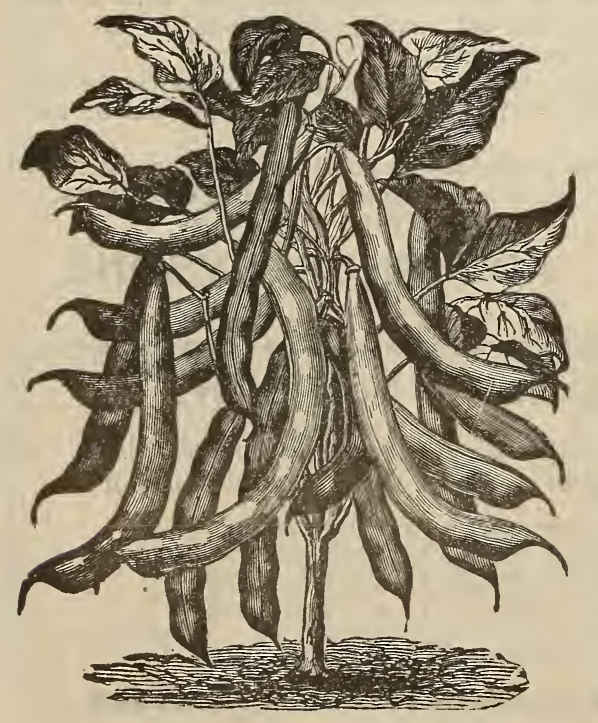

Challenge Black Wax-The best early wax bean for the market. The plants in growth and general appearance resemble the old Black Wax or Butter Bean, and are very productive. The pods are clear waxy white, quite round, very crisp, tender and stringless. The dry bean is jet black. Pkt. 5c; $1 / 2$ pint IOc; pint 20c; quart $35 \mathrm{c}$.

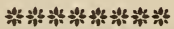

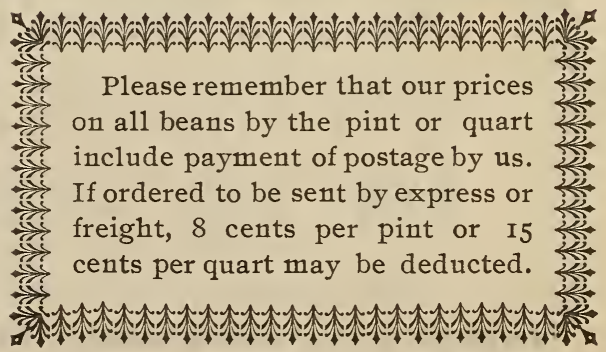




\section{Dwarf and Green Pod Varieties.}

Extra Early Refugee-The earliest of the green podded kinds, furnishing a fleshy pod of fine quality. The vines are a little smaller and more upright growing and the leaves distinctly lighter colored than those of the late Refugee, though the dry beans are of the same size, shape and color. Our stock has been selected with great care and is extremely uniform, all the vines ripening their pods well together and long before those of the common Refugee are usable. Pkt. 5c; $1 / 2$ pint roc; pint $20 \mathrm{c}$; quart $35 \mathrm{c}$.

Refugee, or Thousand to One-Vines large, spreading, exceedingly hardy, with small, smooth leaves and large lilac flowers, very large, and esteemed for late planting and for use as pickles; pods long, cylindrical. green, becoming white, streaked with purple, of good quality as snaps; beans long, light drab, dotted and splashed with purple. Pkt. 5c; $1 / 2$ pint Ioc; pint $20 \mathrm{c}$; quart $35 \mathrm{c}$.

Early Mohawk-The hardiest of the early varieties, and on this account is considered the best for early planting; pods pale green, long and flat, seeds large, kidney shaped, brown and marbled purple. Pkt. 5c; $1 / 2$ pint Ioc; pint $20 \mathrm{c}$; quart $35 \mathrm{c}$.

Extra Early Round Pod Red Valentino-For snaps there is nothing superior to this variety among the green podded sorts, and many prefer it to the wax varieties. Vines erect, with coarse, dark green leaves and large white blossoms; pods medium length, curved, cylindrical, with crease in back, very fleshy crisp and tender; beans medium size, long irregular, pink, marbled with red. Among green podded varieties there is none, we think, that can compare with our stock of Valentine in fleshiness and high quality of pod. Many different strains of Valentine are offered under slightly varying names, each claiming to be a great and distinct improvement. We have carefully examined them all, both in trials and large yields, and have found none which we were willing to substitute for our old stock, which combines in a high degree all the good qualities of the sort. Pkt. 5C; 1/2 pint roc; pint $20 \mathrm{c}$; quart $35 \mathrm{c}$.

California, or Prolific Tree-A strong grower, bearing its load of pods well up from the ground; not liable to rust; beans small, uniform in size, white and of good quality; resembles the Old Navy Bean, but is more productive; a superior field variety. Pkt. 5c; $1 / 2$ pint Ioc; pint 20c; quart 35 c; peck 85 c; bu. $\$ 3.25$.

Improved White Navy-Standard variety for field culture, very productive and only for culinary purposes in a dry state. Pkt. $5 \mathrm{c}$; $1 / 2$ pint Ioc; pints $20 \mathrm{c}$; quart 35.

White Marrowphat-Extensively grown in field crops for sale as a dry bean for winter use. Pkt. 5c. $1 / 2$ pint Ioc; pint 20c; quart 35 .

Henderson's Bush Lima-This is a bush variety of the small Lima, a very rich, luscious bean that has the advantage of not requiring poles to run on, while it comes earlier into bearing. The Bush Limas are now very popular. Pkt. 5c; $1 / 2$ pint I5c; pint 25c; quart $40 \mathrm{c}$.

Burpee's Bush Lima-Burpee's, the only busl form of the true, luscious, large Lima. It is pronouncer by all good judges as unquestionably the real Bush Lima. The bushes grow eighteen to twenty inches high, of stout growth and always erect. It is an immense yielder, the pods being filled with very large beans. Pkt. $5 c$; $1 / 2$ pint I5c; pint $25 \mathrm{c}$; quart $40 \mathrm{Oc}$.

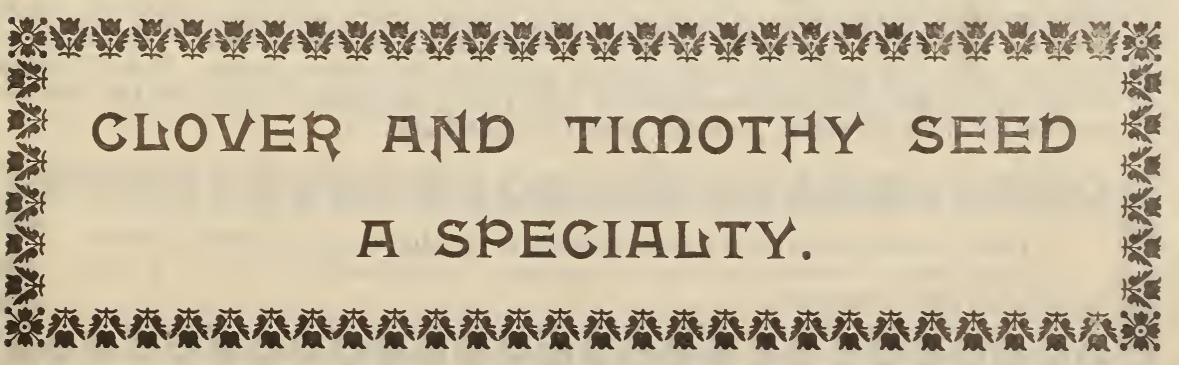


Burpee's New Stringless-This new bush bean is one of the most desirable ever introduced, and we highly recommend it. The introducer describes it as follows: "It is most happily named, as it is quite unique-the only stringless green-pod bush been in culti vation. Consequently it surpasses all others in crisp tender flavor. The il.1 ustration herewith taken from nature, shows the width and th i c kness of the beautiful straight, green pods; all are a b solute 1 y stringless and of the beautiful fleshy appearan ce shown. The pods are ready to market two weeks earllier than the best stock of Improved Extra Early Red Valentines, in fact earlier than the Early Yellow Six W e eks, which, as all know, is valu-

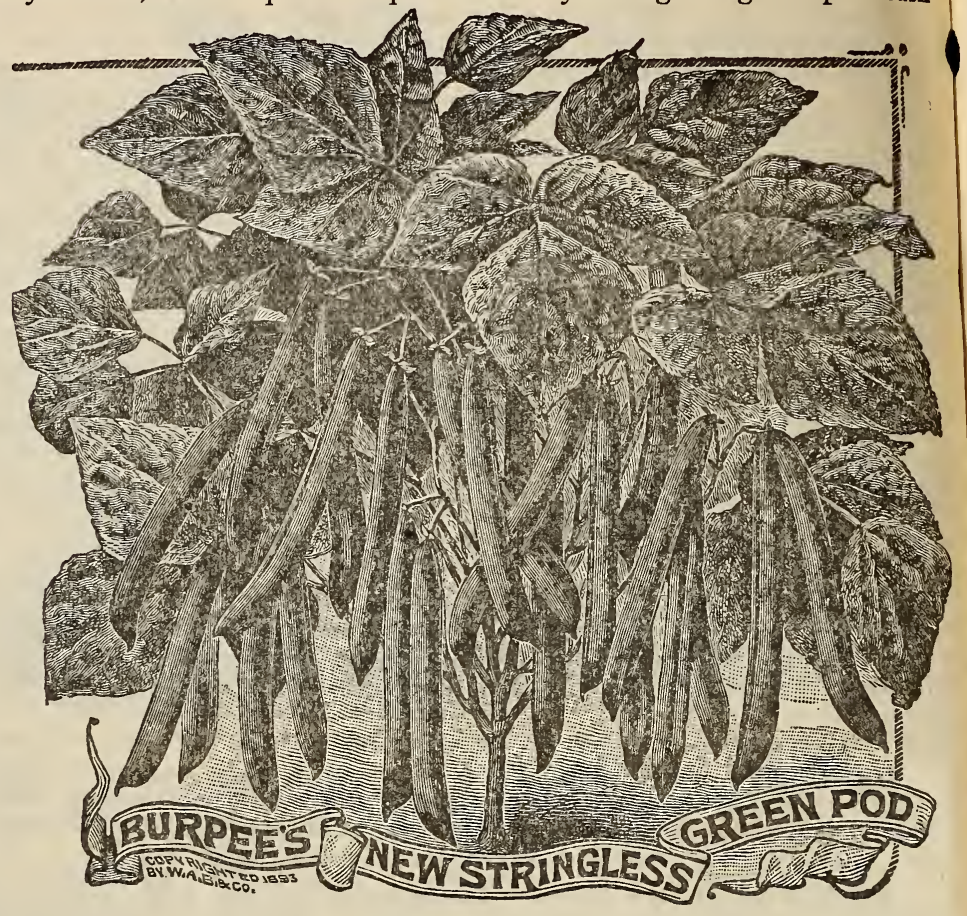
able only for its extra earliness, being of an inferior quality. Burpee's Stringless green-pod is of immense value, not only to the market gardener who wants to make more money, but also to the amateur who' seeks finest quality for the home. Pkt $5 \mathrm{c}$; $1 / 2$ pint $15 \mathrm{c}$; pint $25 \mathrm{c}$, quart $40 \mathrm{c}$.

\section{Pole Beans.}

Early Large White Lima-A greatly improved variety of excellent quality, Vine tall growing and vigorous; leaves medium size, light green; blossoms small, white; pods borne in clusters, long, broad, very thin, dark green; beans large, kidney shaped, greenish-white, flat. Pkt. $5 \mathrm{c}$; $1 / 2$ pint $15 \mathrm{c}$; pint $25 \mathrm{c}$; quart $35 \mathrm{c}$.

King of the Garden Lima-Claimed to be larger, stronger growing, more productive, and with larger pods and beans than the Large White Lima. On account of its large pods it is a favorite with market gardeners in many places. It will come into bearing sooner, and will make larger pods if not more than two vines are left to grow on a pole. Pkt. $5 \mathrm{c}$; $1 / 2$ pint $15 \mathrm{c}$; pint $25 \mathrm{c}$; quart $40 \mathrm{Oc}$.

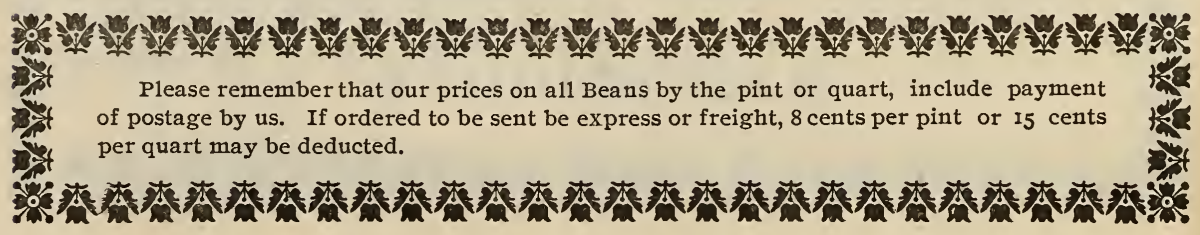




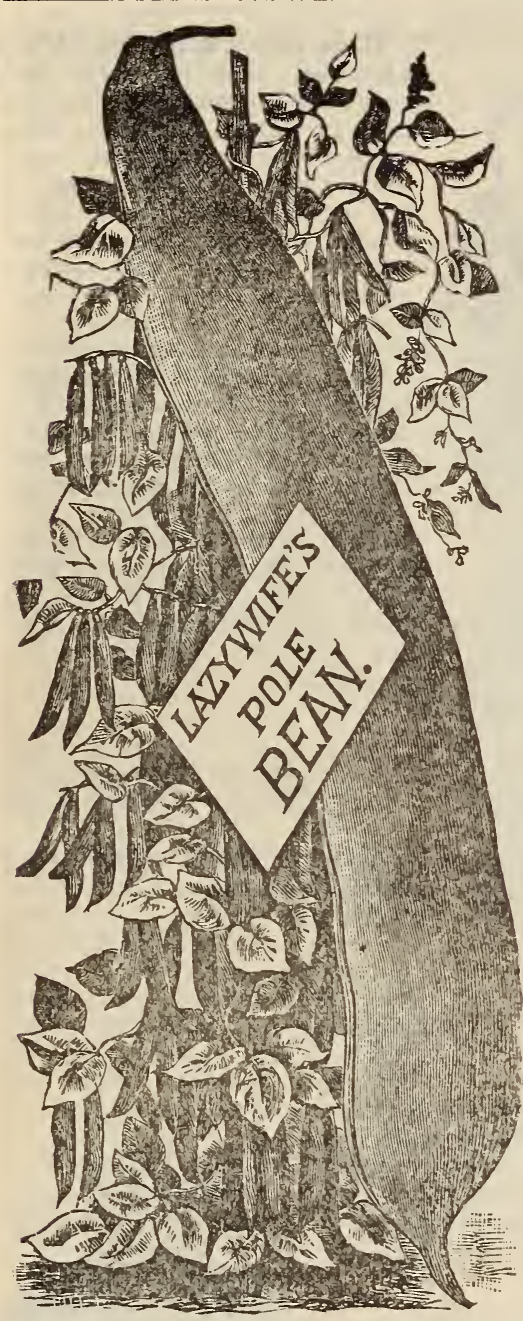

Southern Prolific-A very prolific sort and popular for snaps. Vines vigorous, with large, thin, smooth leaves; blossoms white; pods produced in clusters, green, cylindrical or thicker than broad, long fleshy, crisp, beans small, oval dun-colored, and somewhat variable in shade. $\mathrm{Pkt}$. $5 \mathrm{c}$ : $1 / 2$ pint $\mathrm{I}_{5} \mathrm{c}$; pint 20c; quart $40 c$.

\section{Speckled Cut-Short or Corn Hill-} An old variety, very popular for planting among corn, and will give a good crop without the use of poles; vines medium, with dark-colored, smooth leaves; pods short cylindrical and tender. Pkt. 5c; $1 / 2$ pint roc; pint 20c; quart $35 \mathrm{c}$.

\section{Horticultural, or Speckled Cran-} berry-A round, speckled, bean, equally good as a snap or shelled bean; used both in the green and dry state. Pkt. 5c; half-pint Io c; pint 20c; quart 35 c.

Lazy Wife-The most popular pole bean growu. Pods are wonderfully broad, thick, and above all entirely stringless. They surpass any other variety in the way vines cling to the poles, and every bean grower will at once acknowledge this a most important qualification. Porls are rather flattish, oval shape, and when fully grown are from four to six inches long exceedingly rich, buttery and fine flavored when cooked. They are hardy, easily grown and most productive. For an early and late snap sort also as a dry shell or winter bean it is unsurpased, and such is the peculiar taste and pleasing flavor of this bean that we have known persons who would not eat other varieties of string beans after tasting Lazy Wife. Pkt. 5c; half-pint Ioc; pint 20c; quart $35 \mathrm{c}$.

Except where noted otherwise, on all seeds ordered by the packet, ounce or pound, pint or quart, but positively not by peck or bushel. 


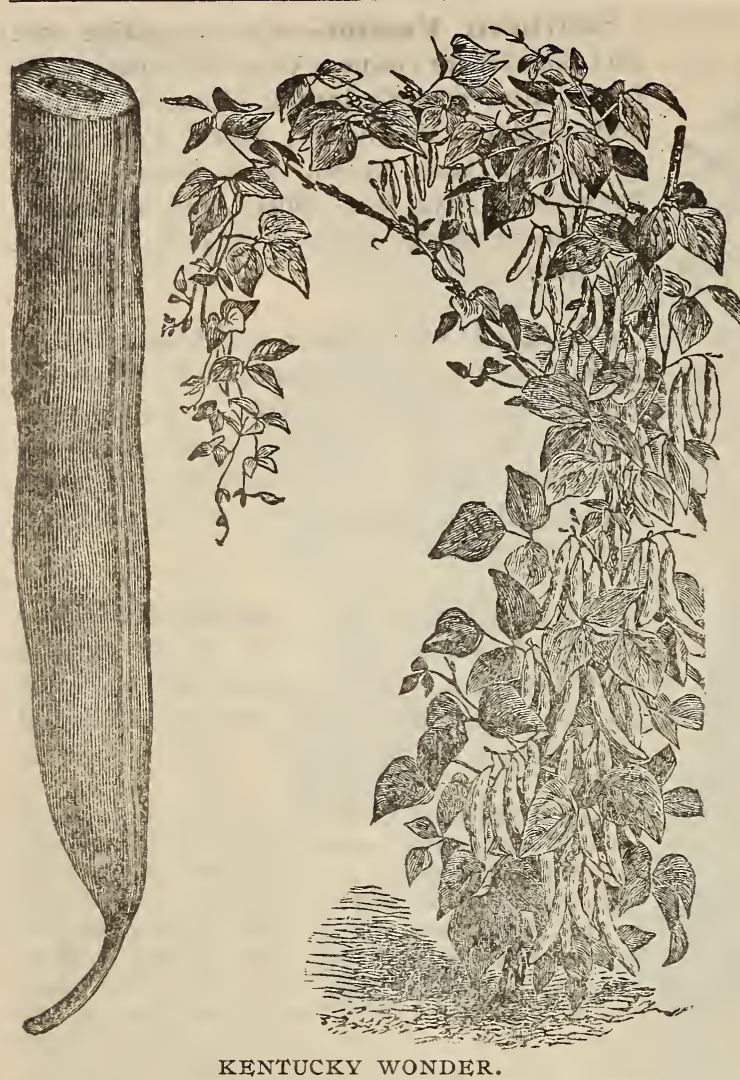

Kentucky Wonder-Vine vigorous, climbing well and very productive, bearing its pods in large clusters, blossoms white; pods green, very long, often reaching nine or ten inches, nearly round when young, and very crisp, becoming very irregular and spongy as the beans ripen. Dry beans long, oval, dun colored. A very prolific sort, with showy pods, which are most excellent for snaps. It is sometimes cotalogued as being the same as Southern Prolific, but this is an error, as the latter is two weeks later, has shorter pods which never become spongy or irregular in shape as they mature, and the dry bean is fully one-fourth smaller. Pkt. $5 \mathrm{c}$; half-pint $\mathrm{I}_{5} \mathrm{C}$; pint $25 \mathrm{C}$; quart $40 c$.

\section{TABLE BEETS,}

Extra Early Egyptian Blood Turnip-The best variety for forcing. Excellent for first early crop out of doors, being very early with small top. Leaf stems and vines dark red, leaf dark green, dotted with red, rounded on top, but flat beneath, with very

small tap root; flesh dark red, zoned with lighter shade; hard crisp and tender when young, but becoming woody with age. Pkt. 5c; oz Ioc; 1b. 50c.

Long, Smooth Bisod - The standard long, late sort. Very dark, blood-red flesh, quality fine. Pkt. 5c. oz. IOc;

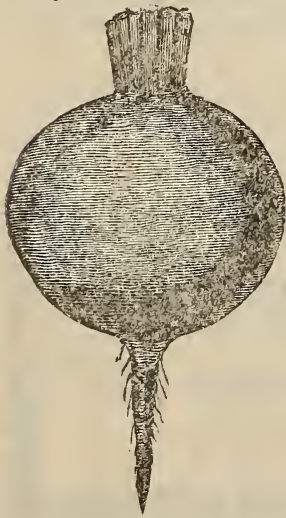
1b. $50 \mathrm{Oc}$.

Edmond's Blood Turnip-This variety has handsome, blood-red roots, which are always round, smooth, and uniform in shade and of good marketabie size, seldom growing too large, as wilh many varieties. The flesh of this beet is unusually sweet and good, and tops are mmall. Pkt. 5c; oz. IOc; lb 5 oc.

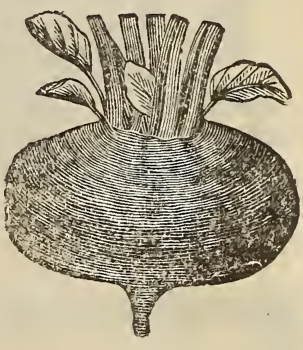

EGYPTIAN.

Farly rips-An improred extra early sort. Tops small, dark fitflish green shading to lighter color on outside of leaves. Koots rearly globular, with a small tap root and a very small collar. Flesh dark red, zoned with a lighter red, very sweet, crisp and tender. especially when young. One of the most desirable scrts for bunching. Pkt. 5c; oz. IOc; 1b. 5oc. 
Golden Tankard-A superior strain of yellow or golden-fleshed mangel; roo half long and very large; an enormous cropper. It is particularly rich in milk pro ducing, qualities, and on this account is highly prized by dairymen. Pkt. 5c oz. IOc. 1b. 5 oc.

\section{CARROTS,}

Danvers--Grown largely everywhere on account of its great productiveness and adaptability to all classes of soil. Tops medium size, coarsely divided. The smooth and handsome roots are deep orange, of medium length, tapering uniformly to a blunt point; flesh sweet, crisp, tender and of a deep orange color. This variety, although the roots are shorter, produces as large a bulk as the longer field sorts, and is more easily harvested. Pkt. 5c: oz. IOc, 1/4 1b. 25c; 1b. 8oc.

Improved Long Orange-The most popular of the older sorts for use on mellow soil. An improvement obtained by years of careful selection of the best formed and deepest colored roots of the old Long Orange. . Roots proportionately shorter than the Long Orange, and smoother, but so uniform and true that the bulk of the crop will be greater. Pkt. 5c; oz. Ioc; 1/4 1b. 35c; 1b. Soc.

Gueranda, or Ox-Heart--This is one of the most raluable sorts, either for family use or market. Intermediate between the half-long and horn varieties, attaining a diameter of three to four inches at the neck, and of the most beautiful shape and color. It is of extra quality and rerv productive. $\mathrm{Pkt}, 5 \mathrm{C} ; \mathrm{Oz}$. Ioc; $1 / 4 \mathrm{~b}$. 25c; 1b. 8oc.

Yellew Belgian-A good field rariety, similar to White Belgian in shape and size, but of orange color. Pkt. 5c; oz. Ioc; 1/ 1b. 25c. 1b. Soc.

\section{CAULIFLOWER.}

Early Snowball-Very early, and one of the surest to make fine large heads. If planted March Ist, large sized heads will be produced early iu June, about one week earlier than other sorts, and scarcely a single head will fail to form. The outer leaves are short, allowing the plants to be set closer together than most varieties. Its dwarf, compact habit of growtl renders it one of the best for forcing under glass. Although cultivated principally for an early crop, it does equally well for late planting. Pkt, Io; oz. \$3.00.

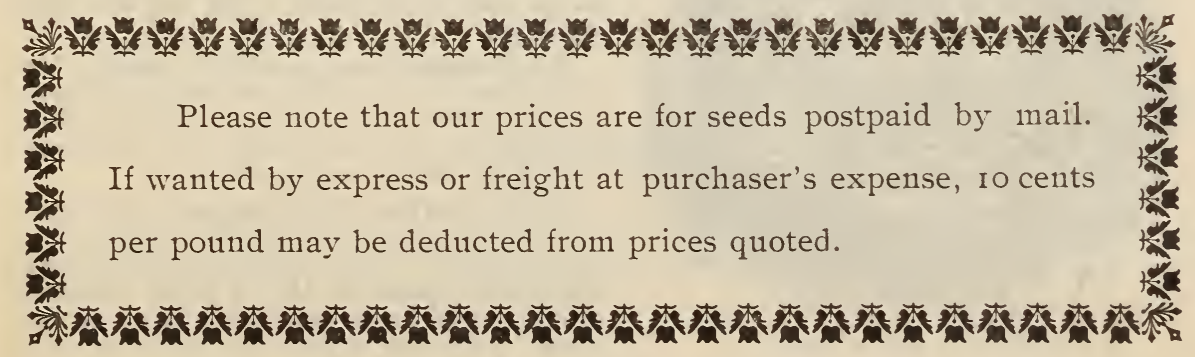




\section{CABBAGE - Early and Summer Varieties.}

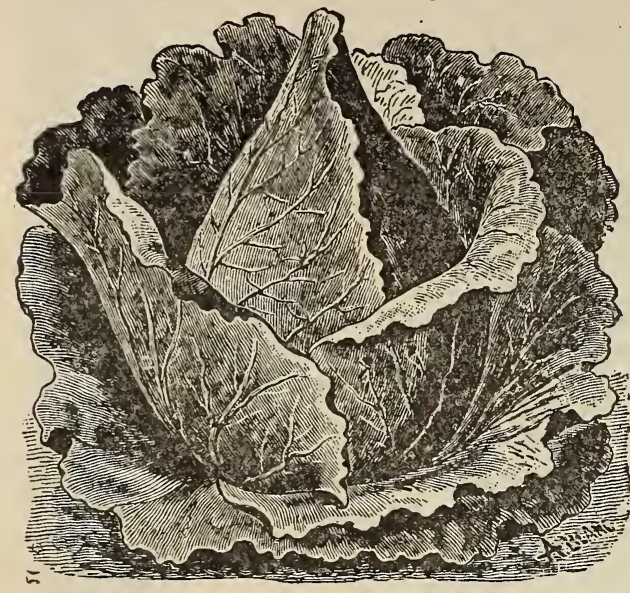

EARIY WINNINGSTADT.

Early Winningstadt-A very fine extra early cabbage. It is larger than the Wakefield, not quite so early; for this reason it is not used as much by market gardeners as Wakefield, but for the home garden it is the most popular of all early varieties. Pkt. $5 \mathrm{c}$; oz. I5 ; 1b. $\$$ r. 50 .

Early Jersey Wakefield-The best early variety of cabbage, and the one most extensively grown for home and market. The heads are of medium size, pyramidal, pointed, firm and solid with few outside leaves; they are very uniform in shape, size and time of maturing, and are of good quality. The variety fully deserves its wide popularity. Pkt. 5c; oz. 20c; $1 / 4$ 1b. 6oc; 1b. $\$ 2$.

Early York-An early variety, heads small, heart-shaped, firm and tender; of very erect and dwarf habit, so that they may grow fifteen or eightteen inches apart. Pkt. 5c; oz. 20c; 2 oz. 35c; 1/4 1b. 6oc; 1b. \$r.50.

Henderson's Early Summer-The standard summer variety. Unexcelled for the market gardener and good for home use. Pkt. 5c; oz. 20c; half-pound 9oc; 1b. \$I.75.

Extra Early Express-An extra early sort, in which the plants are compact, with thick round leaves, and form an oval head, which is astonishingly large for the size of the plants. The heads are proportionately thicker and less pointed than those of the Jersey Wakefield, and it is only slightly later than that sort. Pkt. 5c; oz. 20c; 1/4 1b. 5oc; 1b. $\$ \mathrm{I} .5 \mathrm{O}$.

Early Dwarf Flat Dutch-Continued experience confirms our belief that this is the best early round-headed sort. The plants are short stemmed and upright, with comparatively few and short leaves, so that they can be planted closely. Heads large, solid, maturing as early is early summer, and stand long without bursting. Pkt. $5 ; \mathrm{oz} .20 \mathrm{c} ; 1 / 4 \mathrm{lb}$. 5oc; $1 \mathrm{~b} . \$ \mathrm{I} .5 \mathrm{O}$.
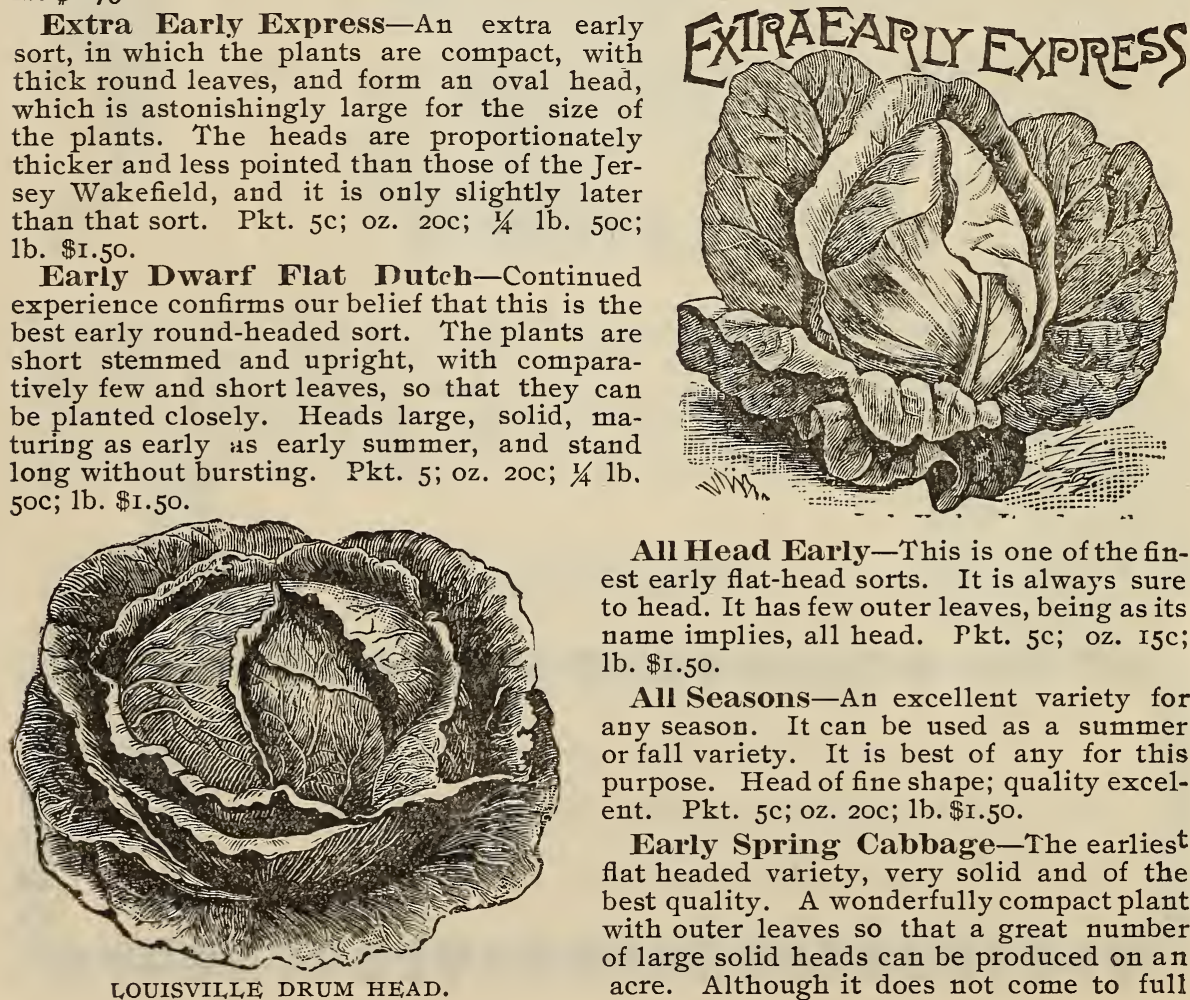

All Head Early-This is one of the finest early flat-head sorts. It is always sure to head. It has few outer leaves, being as its name implies, all head. Pkt. 5c; oz. $15 \mathrm{c}$; 1b. $\$$ I.5o.

All Seasons-An excellent variety for any season. It can be used as a summer or fall variety. It is best of any for this purpose. Head of fine shape; quality excelent. Pkt. 5c; oz. 20c; 1b. \$r.5o.

Early Spring Cabbage-The earliest flat headed variety, very solid and of the best quality. A wonderfully compact plant with outer leaves so that a great number of large solid heads can be produced on an acre. Although it does not come to full 
maturity as Jersey Wakefield it becomes solid enough for use about as ea rly and is by far the best early sort for those markets that demand a cabbage of the Flat Dutch type. The plant is vigorous, with short stem. The leaves are large, broad and of peculiar light green color The heads are oval and very large for the size of the plant. nearly equaling those of the later kinds. Pkt. $5 \mathrm{c} ;$ oz. $60 \mathrm{c} ; 2$ oz. $85 ; 1 / 41 \mathrm{~b} . \$ 1.50 ; 1 \mathrm{~b} . \$ 5$,

\section{Late Varieties.}

Louisville Drumhead-This variety is gaining in popularity as a summer and winter cabbage. Following Early Summer, heads very large and solid, few outer leaves, stem short, resists heat and drouth to a remarkable degree, and stands a long time without bursting, a good one, try it. Pkt. 5c; oz. 15c, 1/4 1b. $40 \mathrm{Oc} ; 1 \mathrm{~b} . \$ \mathrm{r} .25$.

Surehead-This popular cabbage is rightly named Surehead, and never fails to make a remarkable fine, solid, large head, with few outer leaves. It originated some years since with a practical gardener, by crossing the Flat Dutch and the Drum. head varieties, and has always brought the highest price in our markets. It is a strong vigorous, ripening late for a main crop, and very uniform in size and color. Pkt. 5c; oz. 20c; I-4 1b. 50c; 1b. \$2.00.

Hollander-This is one of the hardiest cabbages in cultivation and endures both frost and drouth that would destroy other varieties. Quite a distinct sort. Plants rather long stemmed, but compact; the leaves are very smooth but thick; the head is of the medium size, round and very solid, being the hardest headed cabbage we know of, and of the very best quality. Matures quite late and keeps well, and is considered by many the best cabbage to hold over for spring markets. Pkt. 5c; oz. 20c; $\mathrm{r}-4 \mathrm{lb}$. $60 c ; 1 b . \$ 2.25$.

American Savoy-Very valuable variety being of much finer flavor and quality than the best of other cabbage. Particularly adapted for private use, where quality, rather than quantity is desired. Grown in fall and allowed to be touched by frost, it is one of the most delicious of all vegetables. Pkt. 5c; oz. r5c; r-4 1b. 40c; $1 \mathrm{~b}$. $\$ \mathrm{r} .50$.

Large, Late Drum Head-A favorite winter variety; extra large, solid heads; slightly later than the Flat Dutch. Pkt. 5c; oz. I5c; I-4 1b. $40 \mathrm{O} ; 1 \mathrm{~b} . \$ \mathrm{r} .25$.

Fottler's Improved Brunswick-This has proved to be a most excellent acclimated second early variety. It is low on the stump, heads solid and compact, weighs from ten to fif-

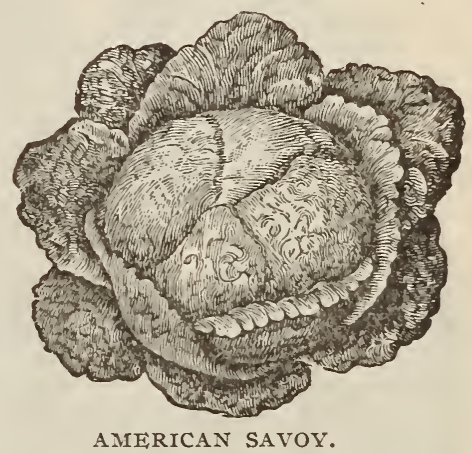
teen pounds each, and is sure to head. From seed sown in March, good-sized heads can be marketed in June. A very valuable variety. Pkt. $5 \mathrm{c}$; oz. I5c. I-4 1b. $40 \mathrm{c}$; 1b. $\$ 1.50$.

Premium Flat Dutch-This old variety is yet largely grown for late or main crop, being a favorite winter market variety. Heads very large, solid and broad; with flat tops of fine flavor and quality, very short stems. Pkt. $5 \mathrm{c} ; \mathrm{oz} ; \mathrm{r} 5 \mathrm{c} ; \mathrm{r}-4 \mathrm{lb} 45 \mathrm{c}$; 1b. $\$ 1.50$.

Faultless-Best second early sort ever grown. It is absolutely faultless, sure to head; large and firm, few leaves, vigorous constitution, rapid grower, and superior for both fall and winter. Excellent keeper. Pkt. 5c: oz. 15c; I-4 lb. 40c; 1 b. \$r.5o.

Early Blood-Red Erfurt-True to type, uniform.y producing very hard heads of intense blood-red color, but very small in size, very early. Pkt. 5c, oz. I5c; r-4 $1 \mathrm{~b}$. $40 c ; 1 b . \$$ r. 50 .

\section{CELERY.}

White Plume-For Fall and early winter use this is the most popular celery. The heart and stock is naturally white, consequently requires very little blanching to be fit for the table. Its eating qualities are equal to the very best of the older sorts, being crisp, solid and of a pleasing nutting flavor, while its white, feather-like foliage places it ahead of all others as a table ornament. Pkt. $5 \mathrm{c}$; oz. $20 \mathrm{c}$; I-4 1b. $65 \mathrm{c}$. 
Golden Self-Blanching-This is without doubt the best celery for early use. The ribs are perfectly solid, crisp, brittle, and of delicious flavor, surpassed by no variety, while it has the decided merit of being self-blanching to a very remarkable degree. The heart is large, solid, and of a beautiful, rich, golden-yellow color. It is an excellent keeper. Pkt. 5c; oz. 25c; I-4 lb. $75 \mathrm{c}$.

Dwarf Golden Heart-A distinct variety of sturdy dwarf habit. It is solid, an excellent keeper and of fine, nutty flavor. An excellent showy and desirable variety for both market and family use. Pkt. 5c; oz. 30c; I-4 1b. 5oc.

Kalamazoo-A celebrated market sort, cf large, neat and rapid growth, and showy appearance. It is remarkable for the even, uniform growth of its stalks, which are close growing, large, thick, solid, crisp and delicious. A good-keeping, first-class celery. Pkt. 5c; oz. 25c; I-4 1b. 8oc; 1b. \$2.75.

\section{CUCUMBER。}

Improved Early White Spine-An excellent variety for table use. Very early grows uniformly straight and smooth; light green with white speckles; tender, of excellent flavor. Very popular. Pkt. 5c; oz. IOc; I-4 lb. 20c; 1b. 50c.

Early Russian-Earliest and hardiest. Vineś productive. Fruit three to four inches long; thick oval, pointed at each end, covered with fine, small spines. Good for table, but not of value for pickling. Pkt. 5c; oz. IO; 2 oz. I5 c. I-4 1b. 20c; 1b. 50c.

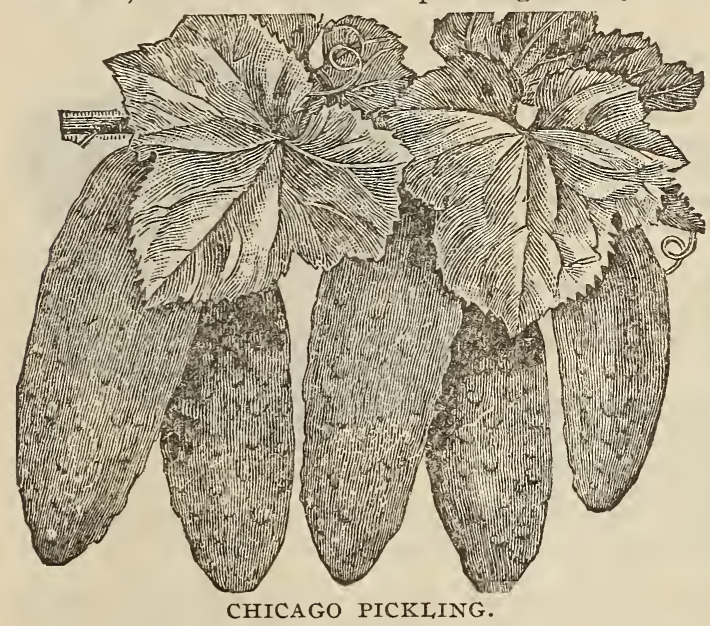

Chicago Pickling-A variety largely used by pickle manufacturers, of medium size, a prolific bearer, and combines all the good qualities of an early cucumber. Pkt. 5c; oz. IOc. I-4 1b. 25c; 1b. $75 \mathrm{c}$.

Early Cluster-Vines vigorous, producing the bulk of the crop near the root, and in ciasters. Fruit short, holding full size to each end. Pkt. 5c; oz. IOc; I-4 1b. 20c; 1 b. 6oc.

Early Short Green-An excellent sort, both for table use and for pickling. Plants very vigorous and productive. Fruit straight, handsome, smaller at each end, bright green, lighter at blossom end, with crisp, tender flesh, and makes excellent pickles. Pkt. 5c; oz. IOc; 2 oz. I 5 c; I-4 1b. 20 c; 1 b. $50 \mathrm{c}$.

Evergreen White Spine-The most popular of all white spined varieties. Of beautiful shape and color. It remains in the green state longer than any other variety. Pkt. 5c; oz. JOc; I-4 1b. 20c; 1b. 6oc.

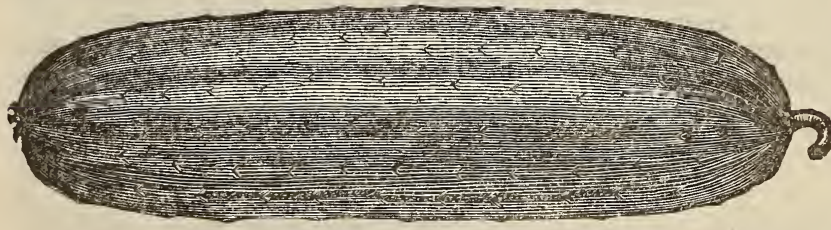

Iimproved Long Green-The leading variety of long, green cucumber, I2 to 16 inches long; of excellent quality; dark green, firm and crisp; most extensively grown. Pkt. 5c; oz. IOc; IMPROVED LONG GREEN. I-4 lb 20c; 1b. 6oc.

Early Frame-Excellent variety for table use; tender and well-flavored, and keeps green longer than any other yariety; also makes splendid hard, green pickles. Pkt. 5c; oz. IOc; I-1 1b. 20c, 1b. 6oc. 
Parisian Prolific Pickling-This is a French sort; a very poor seeder, but distinct and valuable. The fruit is very long, slender, cylindrical, densely covered with fine prickles, and deep, rich green color. The flesh is very crisp and tender, making it one of the best for slicing, as well as for pickles. Pkt. 5c; oz. Ioc. $1-41 \mathrm{~b} .20 \mathrm{c} ; 1 \mathrm{~b}$. 6oc.

Green Prolific, or Boston Pickling-One of the most prolific of the pickling sorts. We can recommend it highly for the home and garden. Pkt. $5 \mathrm{c}$; oz; IOc; I-4 1b. $20 c ; 1 b .60 c$.

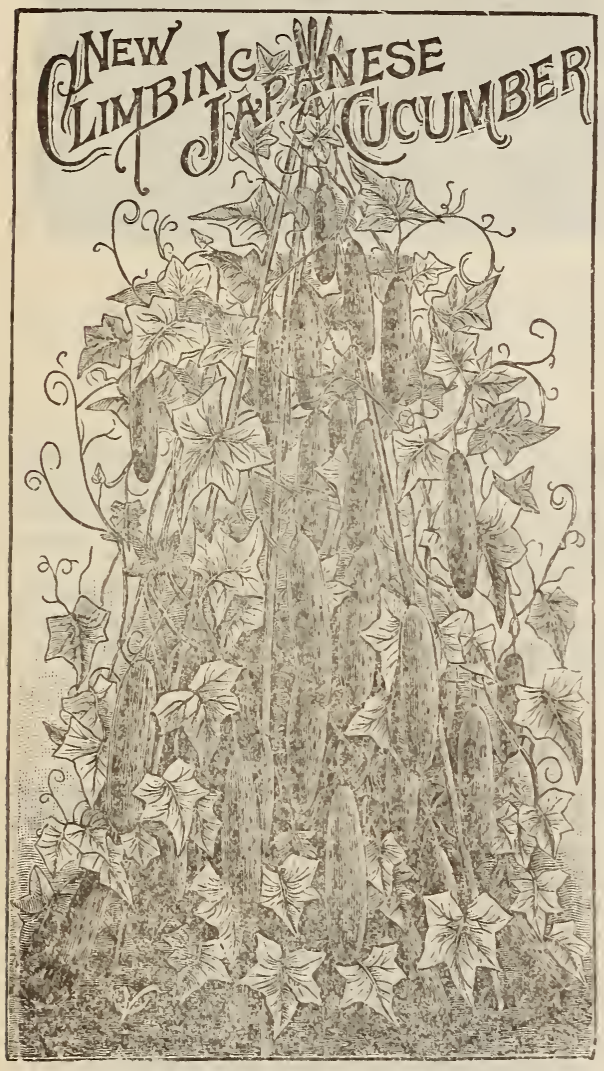

New Climbing Japanese-Vines are extra strong and foliage much more vigorous than other kinds, and being a climbing sort, can be grown on trellises, fence, etc., saving valuable space in small gardens. It is very prolific, from 40 to 60 cucumbers having been grown on single plants; fruit cylindrical, about ten inches long, thick and of fine flavor. Pkt. 5c; Oz. IOc; I-4 lb. 30c; 1b. \$I.

\section{LEEK.}

Leek belongs to the onion family and by some preferred to that vegetable. Sow the seed and care for young plants same as for onions, but they need a little more room in order to develop fully. When the young plants are about the size of a goose quil, transplant to a prepared bed in rows one foot apart and four or five inches to the row. Set the roots deep and draw the earth to them when cultivating, so that they may be well blanched by the time they are fit for use.

Musselburgh-A hardy popular sort, with broad-spreading leaves and very large stalks. Pkt. $5 \mathrm{C}$; Oz. I5 $\mathrm{C}$; $\mathrm{I}-4$ 1b. 5 oc; lb. $\$$ I. 75 .

\section{KALE.}

Tall Curlod Scotch-A hardy grower of excellent quality. Pkt. 5c; oz. IOc; 1b. \$I.OO.

Dwarf Curled Srotch-The most popular.sort; quality excellent. Very hardy. The best for market gardeners. Pkt. 5c; oz. Ioc. I-4 1b. 30c; 1b. \$I.00.

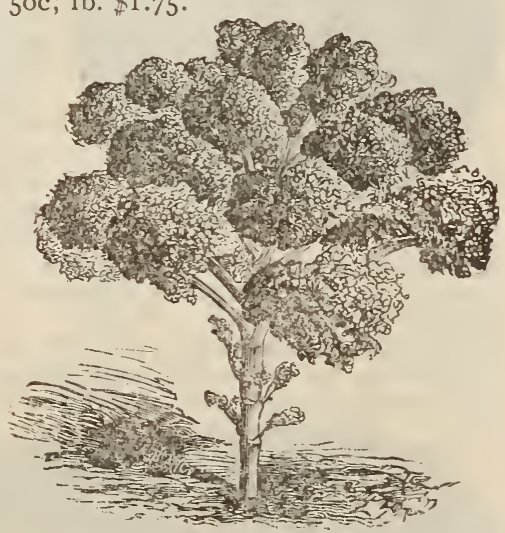

GREEN SCOTCH KALE. 


\section{CRESS, OR PEPPER GRASS „Curled.}

True Upland-Grows similar to spinach and used exactly as water cress. Its usage should be more general, as it is as easy of culture as spinach. It is a perrenial plant, and can be grown for several years without renewal. Pkt. $5 \mathrm{c}$; oz. 5 oc.

\section{MUSTARD.}

White and Brown-Both varieties are sown like cress, and used as it is, as a small salad. The seed of the white

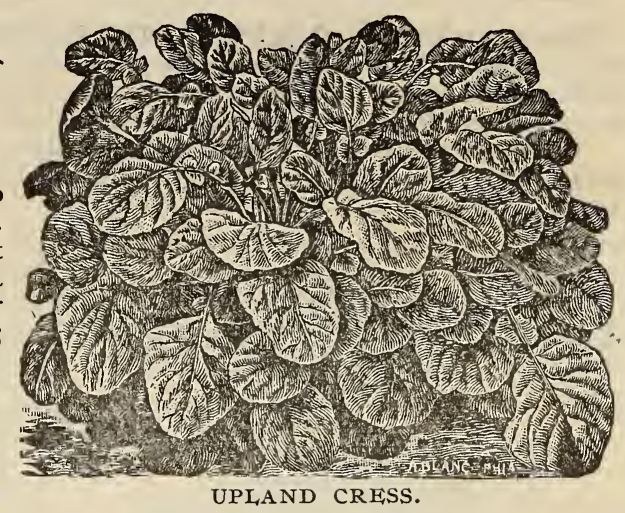
has proved useful in dyspepsia. From the seed of the brown is manufactured the condiment in daily use. Pkt. 5c; oz. roc; r-4lb. r5c; 1b. $40 \mathrm{O}$.

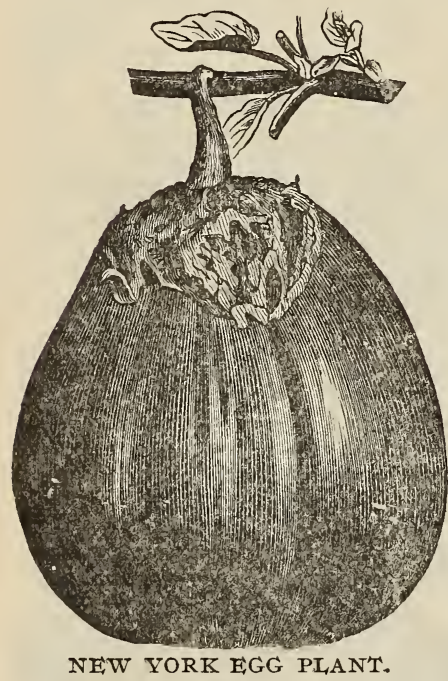

\section{EGG PLANT.}

Improved Large Purple-Fruit remarkably large, often measuring twelve inches in depth and nine inches in diameter, weighing five to six pounds. Skin deep purple with occasional stripes of green about the stem. Pkt. 5c, oz. 40c.

New York Improved Purple- a superior market variety. It grows to a large size, oval shaped aud dark purple color. Pkt. 5c; oz. 50c; I-4 lb. $\$ \mathrm{I} .25$; 1b. $\$ 4.00$.

\section{SUGAR CORN,}

Country Gentleman-This is the variety parexcellence for quality. It is medium early, rows zig-zag, grain long, flavor beyond description; excelent for canning. Pkt. 5c; pint r5c; qt. 3oc, pk. 75c.

Stowell's Evergreen-Now recognized every. where as a standard variety, both for home use and market, and is the general favorite. The ears are of a large size, grain deep, exceptionly tender and sugary, and has the advantage of remanning longer in the green state than any other. Our stock has been carefully grown and selected to avoid the tendency to a shorter grain and deterioration in the evergreen character of this best of all late sorts. Pkt. 5c; pint $\mathrm{r}_{5} \mathrm{c}$; qt. $30 \mathrm{c} ; \mathrm{pk}$. $75 \mathrm{c}$.

Early Minnesota-This old and deservedly popular variety is one of the best early sorts for the market and private garden. Stocks short and not suckering, bearing one or two ears well covered with husks; ears long, eight rowed, kernels very

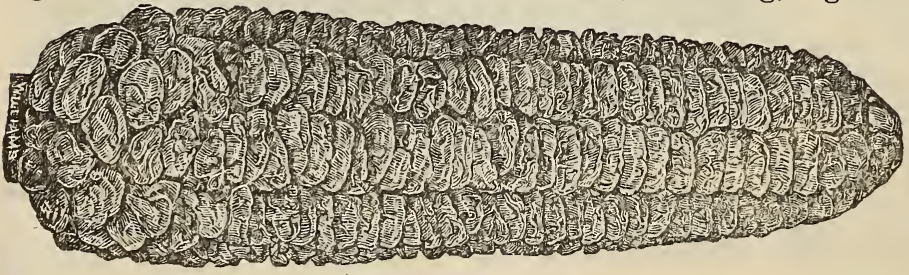

EARIY MINNESOTA. broad, sweet and tender, not shrinking much in drying. By careful selection we have developed a stock of this standard variety which is remarkably uniform and in which 


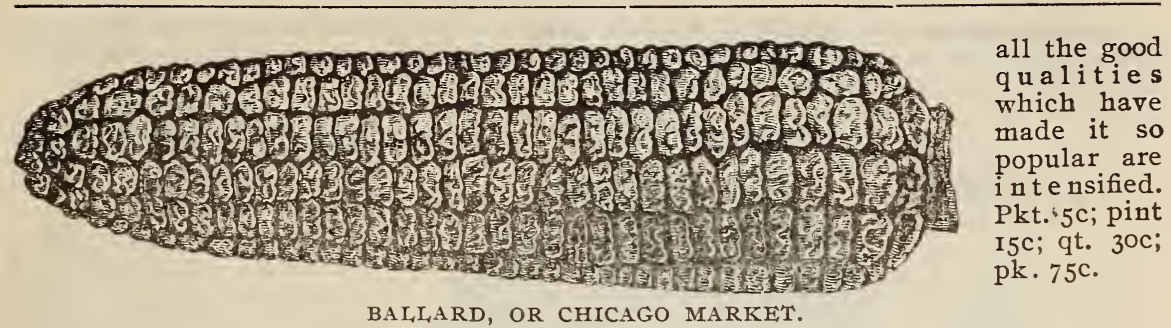

BALLARD, OR CHICAGO MARKET.

Ballard or Chicago Market-The largest and best early corn in existence: twelve rowed, large eared, white cobbed, of choice quality and exceedingly productive. Pkt. 5c; pint $15 \mathrm{c}$; qt. $30 \mathrm{c}$; pk.75c.

\section{LETTUCE,}

St. Louis Market-The best head lettuce. Popular with Chicago market gardeners. The best for summer use. Pkt. 5c; oz. Ioc; I-4 1b. 30c; 1 b. \$I.0O.

Black Seeded Simpson-The leaves are very large, and form a compact mass rather than a distinctive head. They are thin, very tender, and of a superior quality and exceedingly popular among market gardeners. Pkt. 5c; oz. IOc; I-4 lb. 35c; $1 \mathrm{~b}$. \$I.

Grand Grapids Forcing-As a forcing variety for winter and early sping use, this stands at the head of the list. It is beautiful in appearance, a strong grower, very tender and crisp, and retains its freshness a long time after being cut. Pkt. 5c; oz. IOc; I-4 1b. 35c; 1b. \$I.0O.

Early Prize Head-Forms a mammoth plant, in which even the outer leaves are crisp and tender, and remains so throughout the season. It is slow to run up to seed, of supreme flavor and very hardy. Pkt. 5c; oz. Ioc; I-4 1b. 30c; 1b. \$r.oo.

Buttercup-Seed white. Plants medium size, with enormous round, smooth leaves, which are of a beautiful yellow color, and very sweet and tender. They form a medium sized, fairly solid head, which, when prepared for the table, are exceedingly attractive in appearance. Pkt. 5c; oz. Ioc; I-4 lb. $30 \mathrm{c} ; 1 \mathrm{~b} . \$ \mathrm{I} .00$.

Hanson-Splendid out-door lettuce; heads very close, solid and large, crisp, tender, sweet; green outside, white within. Pkt. 5c; oz. IOc; I-4 lb. 30c; 1b. \$I.Oo.

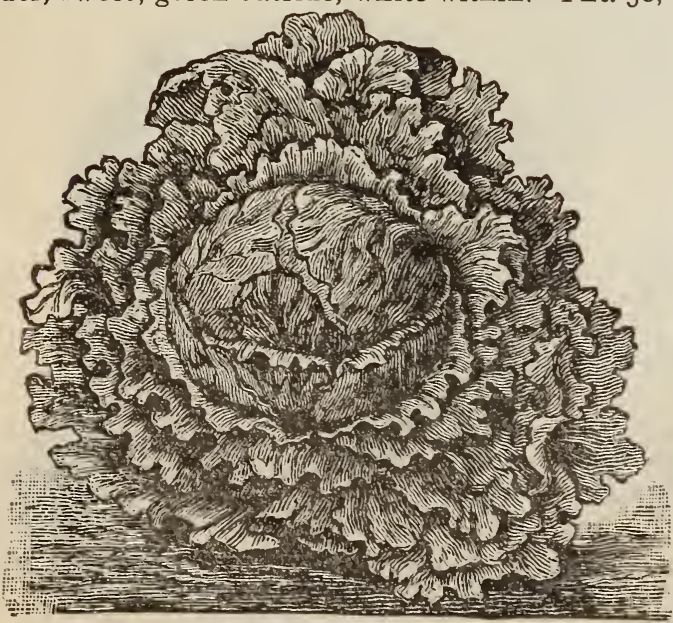

Simpson's Early CurledSeed white. Similar to the last, but the plant is smaller and decidedly darker in color, and the leaves are more frilled and blistered. Popular in New York markets. Pkt. $5 \mathrm{c}$; oz. IOc; 2 oz. 20c; I-4 1b. 30c; 1b. \$I.0o.

Early Curled Silisia-Seed white. An early, erect growing, loose heading variey, which may be used very young, when it is exceedingly sweet and well flavored. Color light green, leaves much frilled and savoyed. Pkt. $5 \mathrm{c} ; \mathrm{oz}$. IOc; 2 oz. 20c; I-4 lb. 30c, 1b. \$I.00.

Chartier-A fine, large heading sort. Thoroughly tried, and found to possess great merit. As will be seen in the cut, it grows very large. Pkt. 5c; oz, IOc; I-4 1b.130c; 1b. $\$ 1.00$. 
Salamander-An excellent summer variety, withstanding drought and heat to a remarkable extent; forms good sized, compact heads, light green outside, white within. Pkt. 5c; oz. IOc; I-4 1b. 30c, 1b. \$I.25.
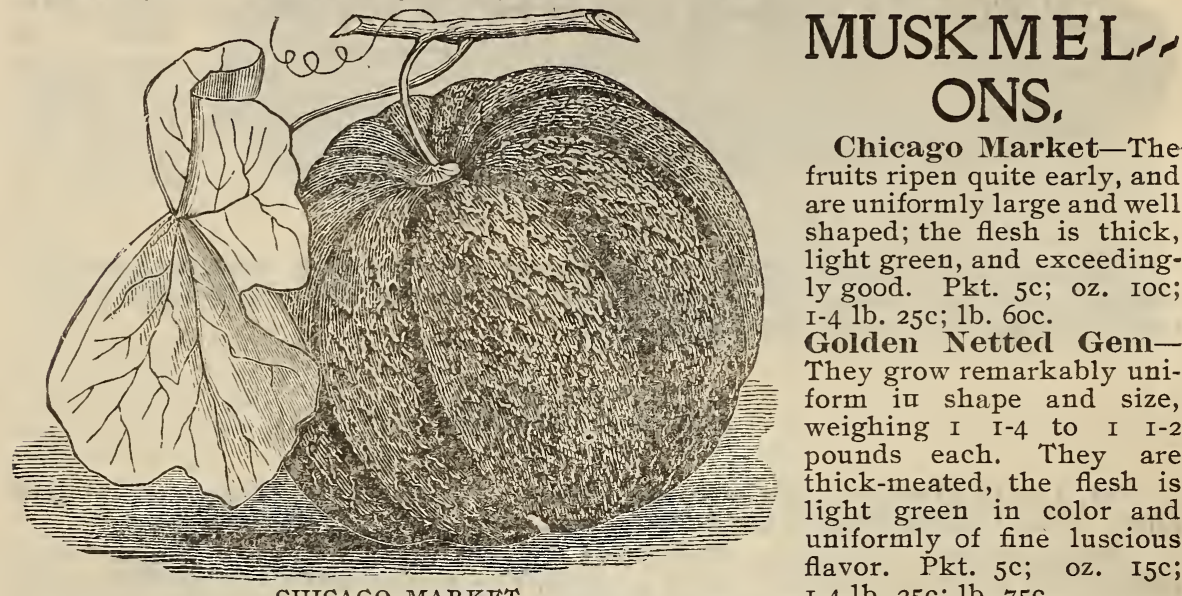

Chicago Market-The fruits ripen quite early, and are uniformly large and well shaped; the flesh is thick, light green, and exceeding$1 y$ good. Pkt. 5c; oz. IOc; I-4 1b. 25c; 1b. 6oc.

Golden Netted GemThey grow remarkably uniform iu shape and size, weighing I I-4 to I I-2 pounds each. They are thick-meated, the flesh is light green in color and uniformly of fine luscious flavor. Pkt. 5c; oz. I5C; I-4 1b. $25 \mathrm{c} ; 1 \mathrm{~b} .75 \mathrm{c}$.

Princess, or Perfection-A notably fine variety, with fruits having flesh so thick and seed cavity so small that they seem almost solid. The rind is thin, tough, and sparingly netted; the flesh a rich salmon color, fine-grained, sugary and melting. The vines are strong-growing and productive; a good market and shipping melon, and also one of the best sorts for home gardens. Pkt. 5c; oz. Ioc; I-4 1b. 25c; 1b. 6oc.

Early Hackensack - This valuable variety is ready for market fully ten days ahead of the well-known Hackensack, which it much resembles in size, shape and quality. They are almost equal in size to the old Hackensack, weighing from five to ten pounds each. It is also very productive, averaging from five to six melons on the vine, all of which are deeply netted. Pkt. 5c; oz. IOc; I-4 1b. 20c; 1b. 6oc.

Shumway's Giant-Very large melons and very uniform in size, whole fields of them averaging from eighteen to twenty pounds. The flesh is very thick, sweet and salmon-colored. It is an excellent shipper. Pkt. 5c; oz. Ioc; I-4 1b. 25c; 1b. $70 \mathrm{c}$.

Bay View-Fruit long and of the largest size, frequently weighing fifteen to seventeen pounds, deeply ribbed and covered with close netting; flesh green, thick and of fine flavor. By far the best of the large melons, and so hady as to be the best sort for inexperienced cultivators. Pkt. $5 \mathrm{c}$; oz. IOc; 1b. 5 oc.

Pineapple-Vines very productive and hardy. Fruit oval, medium size, slightly ribbed and dark green at first, but becoming covered with shallow gray netting as they mature. Flesh green, delicate, exceedingly sweet and high flavored. Pkt. 5c; oz. Ioc; $1 \mathrm{~b} .50 \mathrm{c}$.

Osage-This one of the most profitable of all melons for the market gardener, of very uniform quality; it makes no difference what the size of the melon may be, large or small, they are all sweet and delicious. The skin is very thin, dark green and slightly netted. The flesh is salmon, remarkably sweet, and of

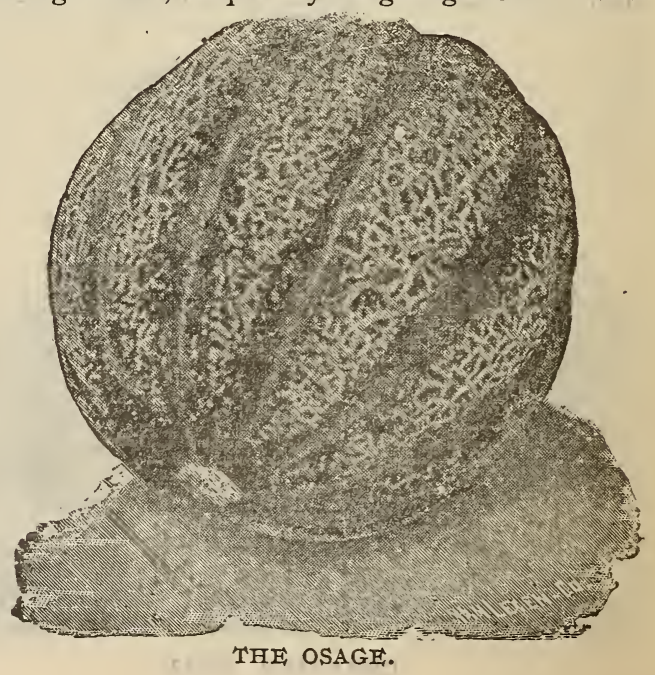


a spicy flavor; extremely thick and delicious to the rind. It is a remarkable keeper and one of the best shipping varieties grown. Pkt. 5c; oz. IOc; I-4 1b. 20c; 1b. 6oc.

Banana-This is a variety of yellow fleshed musk melon entirely free from netting. The skin is of a delicious straw color; the flesh is quite thick and blends from a bright green to rich salmon color, making a fine and striking contrast. It is early, prolific, quality equal to the common Musk Melon, and has a delicious fragrance. When ripe it reminds one of the overgrown banana. Pkt. 5c; oz. I5c; I-4 1b. $25 \mathrm{c} ; 1 \mathrm{~b} .90 \mathrm{c}$.

Tip-Top-This is a fine, round melon of such attractive appearance that readily makes it a selling variety in the market. Every fruit, whether large or small, early or late in the season, is of delicious, sweet, juicy flavor; the flesh is firm, but not hard and eatable to the very outside coating. In productivness it is unexcelled, being a strong and willing grower. Pkt. $5 \mathrm{C}$; Oz. I5c; I-4 1b. $25 \mathrm{c} .1 \mathrm{~b} .75 \mathrm{c}$.

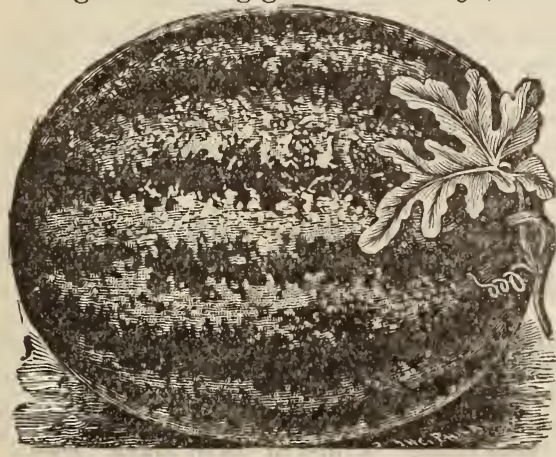

JUMBO.

\section{WATERMELONS,}

Jumbo-The shape of this new melon is almost round. The skin is green, with faint stripes of lighter green. In form and habit of resting on the blossom end, it is like the Pride of Georgia but is free from the ribs of that variety. As indicated by the name, they grow to a fine large size with a very tough rind, making it a valuable shipping variety. Flesh red and very sweet. Pkt. 5c; oz. IOc; I-4 lb. 20c; 1b. 65c.

Kolb's Gem--Vines of medium size, but remarkably vigorous and healthy. Leaves of medium size, deeply cut with a peculiar frilled edge. Fruit of the largest size, round or slightly oval, marked with irregular mottled stripes of dark and light green. Outer rind or shell exceedingly hard and
firm, making it a good sort for shipping long distances. Fresh dark red, solid a little coarse, but sweet and tender. Seeds dark gray. Pkt. 5c; oz. Ioc; 1b. 5oc.

Sweet Watermelon-One of the best melons ever introduced. Vines vigorous and productive, ripening its fruit e arly; fruit large, oval, very heavy, uniformly mottled light and very light green. Rind thin, but firm, flesh bright red, firm, solid, very tender, melting and sweet. G o o d shipper and 1 o ng keeper. Offered for the first time in I894, and is now one of the most popular sorts in c ul t iv a tion. Carloads of Sweethearts are

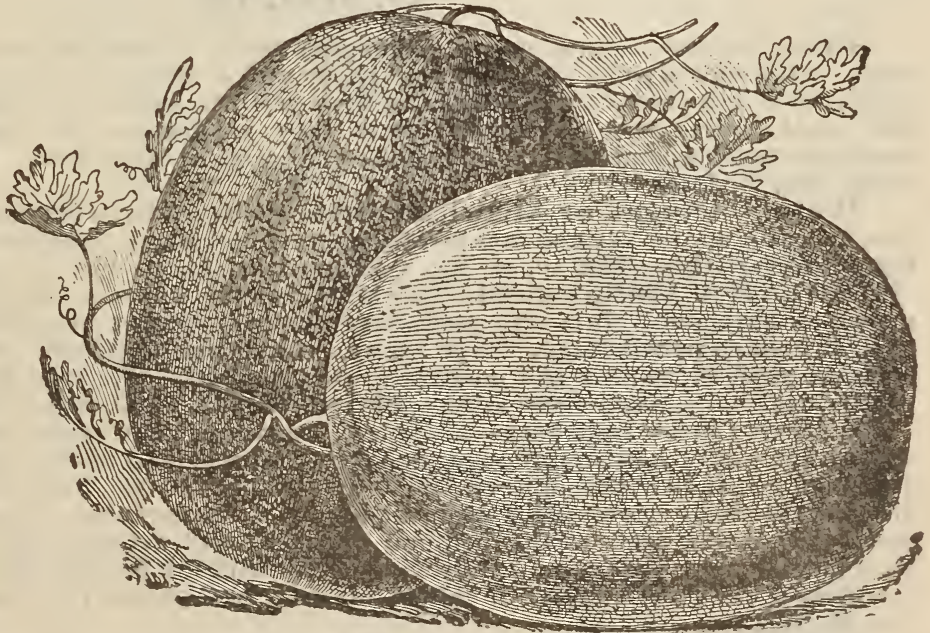

SWEETHEART WATERMELOM. sold at fancy prices when no other sorts are salable. The seed we offer was grown from headquarters. Pkt. $5 \mathrm{c}$; oz. IOc; I-4 1b. 20c; 1b. $75 \mathrm{c}$.

Gypsy, or Georgia Rattlesuake-One of the largest varieties and stands ship- 
ment long distances. Fruit cylindrical, square at the ends, smooth, distinctly striped and mottled dark and light green. Flesh bright scarlet and very sweet. Pkt. 5c; oz. IOc; 2 oz. I5c; I-4 1b. 30c; 1 b. 5 Oc.

Seminole-One of the best in cultivation and pronounced a perfect melon in every respect. It is extra early, enormously productive, solid, ripening clear to the rind, color gray and light green, and of excellent flavor. Pkt. $5 \mathrm{c}$; oz. IOc; I-4 lb. 20c; 1b 6oc.

Phimney's Early-A valuable variety for use in the north; hardy and a sure cropper. Vines vigorous and productive, fruiting quite early; fruit medium size, oblong, smooth, marbled with two shades of green; rind thin, flesh pink, very sweet, tender and crisp. Pkt. 5c; oz. Ioc; 2 oz. I5c; I-4 lb. 20c. 1b. $50 \mathrm{c}$.

Black Spanish-Vines small so that they may be planted closer than most sorts. Fruit round, very dark green, with sweet, scarlet flesh and black seeds. It is not so large as some of the other sorts, but is yery hardy and a sure cropper. Pkt. $5 \mathrm{c}$; oz. IOc; I Oz. I5c; I-4 1b. 20c; 1b. 5oc.

Ice-Cream, or Peerless-It is a superior variety in every respect, and has a beatiful crimson core, is fine-grained and cannot be surpassed in excellence. Very prolific, sweet, and rind thin. Pkt. 5c; oz. IOc; I-4 1b. 20c; 1b. 50c.

Iron-Clad-Grows to a very large size, frequently weighing 60 pounds and over. The flesh is deep red and of a delicious flavor; holding its fine qualities very close to the skin. For shipping qualities the Ironclad is unsurpassed. The vines are strong growing. Pkt. 5c. oz. IOc; I-4 1b. 20c; 1b. 6oc.

Mountain Sweet-Ove of the best for early culture. Color dark green, rind thin; flesh scarlet, solid, very sweet and delicious. Pkt. 5c; oz. Ioc; I-4 1b. 20c; 1b. 50c.

Vick's Early-A well-known early kind. Seed black, smooth and shiny, quality fine. Pkt. 5 c; oz. Ioc; 1b. 5oc.

Cuban Queen-Fruit medium size to large, globular or oval, skin striped light and dark green in sharp contrast, rind medium thick, but stands shipment well. Flesh bright red, solid, very crisp and sugary. Pkt. $5 \mathrm{c}$; oz. Ioc; I-4 1b. 20c: 1b. $50 \mathrm{c}$.

Dixie-A popular market sort. Vines vigorous, large growing and hard. Fruit medium size to large, about one-third longer than thick. Color of skin dark green, striped with a lighter shade. Rind thin and tough. Flesh bright scarlet, ripens closly to the rind, and is of the best quality and free from the hard, coarse center which is so objectionable a feature of many shipping melons. Pkt. 5c, oz. IOc, I-4 1b. 20c, 1b. $50 \mathrm{c}$.

\section{ONIONS,}

Prize Taker-Enormous size, averaging twelve to fourteen inches in circumference. Although of great size, it is very hardy and a very fair keeper. The outside skin is of a rich yellow color, while the flesh is white, sweet and tender. They bottom well are free from stiff necks. It is very productive. In market it attracts marked attention, and sells readily double the price of other sorts. Pkt. $5 \mathrm{c}, \mathrm{oz}$. I5c, I-4 1b. 5oc, 1b. \$I.5o.

White Portugal, or American Silver Skin-A large flat onion of mild flavor, fine for early winter use and much esteemed for pickling. It is the best keeper of the white varieties. Pkt. 5c, oz, 20c, I-4 lb. 6oc, lb. $\$ 2.00$.

Large Red Wethersfield-This is the favorite onion where immense crops are grown for shipment. It is very productive, the best keeper in cultivation, of large size, skin deep purplish-red, shape round, somewhat flattened, strongly flavored, with purplish white flesh and moderately fine grained. The most popular onion for family use and general cultivation. Pkt. 5c, Oz. IOc, I-4 1b. 35c. I-21b. $65 \mathrm{c}, 1 \mathrm{~b}$. \$I.25.

Yellow Globe Danvers-The Ideal Danvers Onion was originally oval or nearly flat, and it has been thought by many that its small neck and splendid ripening habit could be obtained in onions of that shape, but we have by careful selection and breeding developed a strain having to a remarkable degree the ripening habit and small neck of the original Danvers, and yet decidely globular in form, thus giving laage yields and handsomer bulbs without sacrificing any of the good qualities of the most popular of yellow onions. Pkt. $5 \mathrm{c}, \mathrm{Oz}$. Ioc, I-4 1b. $35 \mathrm{c}$. I- $\mathrm{I}$ Ib. $65 \mathrm{c}, 1 \mathrm{~b} . \$ 1.25$.

Southport White Globe-This is a very large and showy, globular, white onion which sells quickly in the market. The bulbs grow quite rapidiy, and if the seed is sown early, good-sized roots, suitable for pulling and marketing in the green state, are soon formed. They are mild flavored, keep well, and the yield is good. Pkt. 5c, oz. $15 \mathrm{c}, \mathrm{I}-41 \mathrm{~b}, 6 \mathrm{oc}, 1 \mathrm{~b} . \$ 2.25$. 


\section{ONION SETS.}

The price per quart will hold good throughout the season, or as long as our stock lasts. If ordered sent by mail, add ro cents per quart for postage.

Red Bottom Sets-Used precisely as top onions are, setting them out in the spring instead of sowing seed. Per quart, $15 \mathrm{c}$.

Yellow Bottom Sets-Identical with the preceeding except in color, and used in the same manner. Per quart $15 \mathrm{c}$.

White Bottom Sets-They do not keep as well as the red or yellow, but produce beautiful white onions early in the season, Per quart, $15 \mathrm{c}$.

Potato Onion-Produces a quantity of young bulbs on the parent root, which should be planted early in the spring, in rows eighteen inches apart, six inches apart in the row, and covered one inch deep. They should be earthed up like potatoes as they continue to grow. Quart I5c, I-4 bushel $\$ 1.00$, bushel $\$ 3.50$.

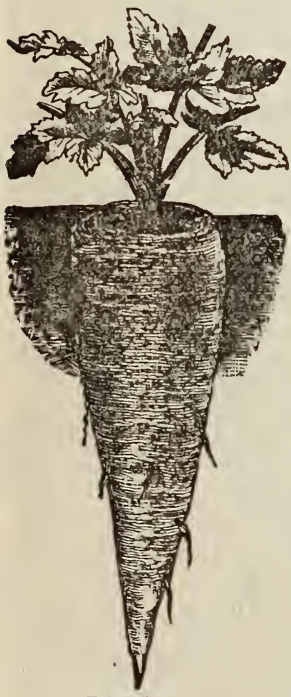

PARSNIP.

\section{PARSNIP,}

Long White Dutch, or Sugar-Roots very long, white, smooth, tender, sugary and of most excellent flavor. Very hardy, and will keep through winter without protection. Pkt. $5 \mathrm{c}, \mathrm{oz} .10 \mathrm{c}, 2 \mathrm{Oz}, \mathrm{I}_{5} \mathrm{C}$ I- 4 1D. $20 \mathrm{c}, 1 \mathrm{~b} 5 \mathrm{Oc}$.

Hollow Crown, or Guernsey-Roots comparatively short with a very smooth, clean skin. The variety is easily distinguished by the leaves arising from a depression on the top or crown of the root. Pkt 5c, oz Ioc, 2 oz I5 c, quarter $1 \mathrm{~b} \mathrm{20c}$, $1 \mathrm{~b} 5 \mathrm{oc}$.

\section{PARSLEY.}

Moss-Curled Leaves crimped and curled like a bed of moss, giving it a most beautiful decorative appearance. Pkt $5 \mathrm{C}$, oz IOc, quarter $1 \mathrm{~b} 20 \mathrm{c}, 1 \mathrm{~b} 75 \mathrm{c}$.

\section{PEPPER,}

Long Cayenne-The variety used for bottled pickling.

Golden Dawn-Plants are quite dwarf, but very prolific. Fruit medium size and of inverted bell shape, rich golden yellow color; with very thick, sweet, mildflavored flesh. Pkt 5c, oz 25c, 2 oz 4 oc. quarter $1 \mathrm{~b} 75 \mathrm{c}$.

Red Chili-Used in the manufacture of pepper sauce. Pods sharply conical and exceedingly pungent when ripe, Requires a long, warm season. The plants should be started quite early in hot beds. Pkt $5 \mathrm{c}, \mathrm{Oz}$ $25 \mathrm{c}, 3 \mathrm{oz} 5 \mathrm{oc}$, quarter $1 \mathrm{~b} 75 \mathrm{c}$.

Ruby King-An improved American sort, reaching the largest size, yet retaining the symmetrical shape of the sualler sorts. It is very bright colored, beautiful; sweet and mild flavored. One of the best for stuffed pickles. Pkt 5c, oz 25c, 2 oz 40c, quarter pound $75 \mathrm{c}$.

Sweet Mountain-Similar to Large Bell in shape and color, but much larger and milder in flavor; used for stuffed pickles. Pkt $5 \mathrm{c}$. Oz 25c, quarter $1 \mathrm{~b} 75 \mathrm{c}$.

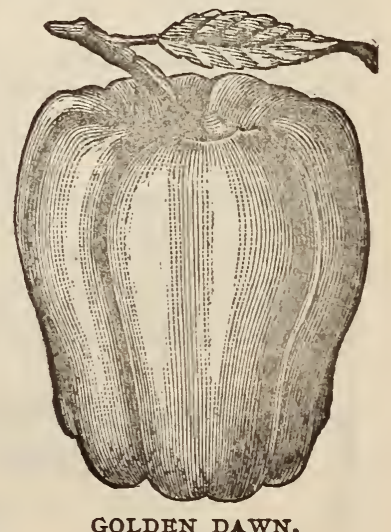

GOLDEN DAWN. 


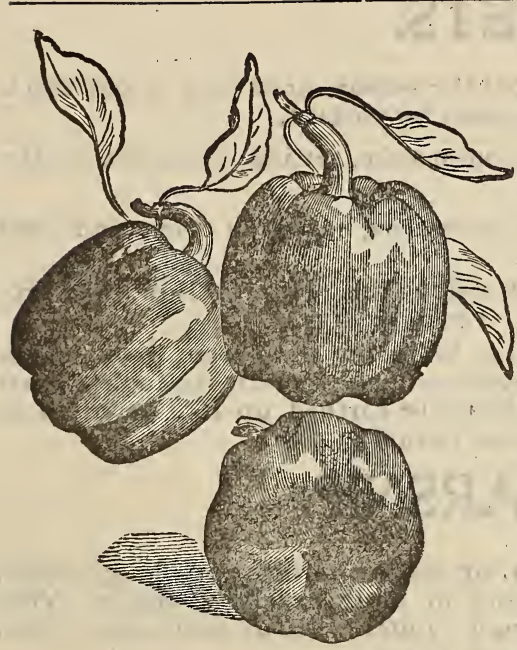

BELL, OR BLUE NOSE,

Large Bell, or Blue Nose.-A very large sort of inverted bell shape, suitable for filling or for a mixed pickle. Flesh thick, hard and less pungent than most other sorts. Pkt. 5c, oz 25c, 2 oz $40 \mathrm{c}$, quarter $1 \mathrm{~b} 75 \mathrm{c}$.

\section{PEAS erExtra Early.}

Alaska-One of the earliest; pods of perfect shape and remarkably well filled; of unrivaled quality for an early pea; height $2 \frac{1}{2}$ feet. Pkt $5 \mathrm{c}$, half-pint loc, pint $20 \mathrm{c}$, quart $35 \mathrm{c}$.

Early Tom Thumb-An early variety nine inches in height; stout and branchiug, pods of good size, very productive and of excellent quality. Pkt $5 \mathrm{c}$, half-pint roc, pint $20 \mathrm{c}$, quart $35 \mathrm{c}$.

McLean's Little Gem-This variety is nearly as early as the American wonder and the vine decidedly larger, growing to a height of twelve to fifteen inches and bearing an immense crop of pods, which are larger, and in-

variably well filled with peas of the finest quality. The dry peas are green, large, wrinkled, often flattened. Market gardeners use more of this sort than any other wrinkled pea, Pkt 5c, half pint roc, pint $20 \mathrm{c}$, quart $35 \mathrm{c}$.

First and Best-Pods good size and well-filled with round, smooth peas of excellent flavor. Extremely early, productive, and ripen all at the same time, therefore a general favorite with market gardeners. Height $2 \frac{1}{2}$ feet. Pkt 5c, half-pint Ioc, pint $20 \mathrm{c}$, quart $35 \mathrm{c}$.

Amorican Wonder-The earliest of all wrinkled peas. Of dwarf habit, growing from nine to twelve inches high, and producing a profusion of good-sized and well-filled pods of the finest flavor. Pkt 5c, half pint Ioc, pint $20 \mathrm{c}$, quart $35 \mathrm{c}$.

Nott's Excelsior.-This excellent new dwarf wrinkled extrit early pea is robust and vigorous in growth, inclined to throw out laterals at the base of the haulm, and produces in profusion long, handsome pods, closely packed with large peas of fine flavor. The pods are fully one-third larger than the American Wonder, containing six or eight fine large peas, packed so closely together in the

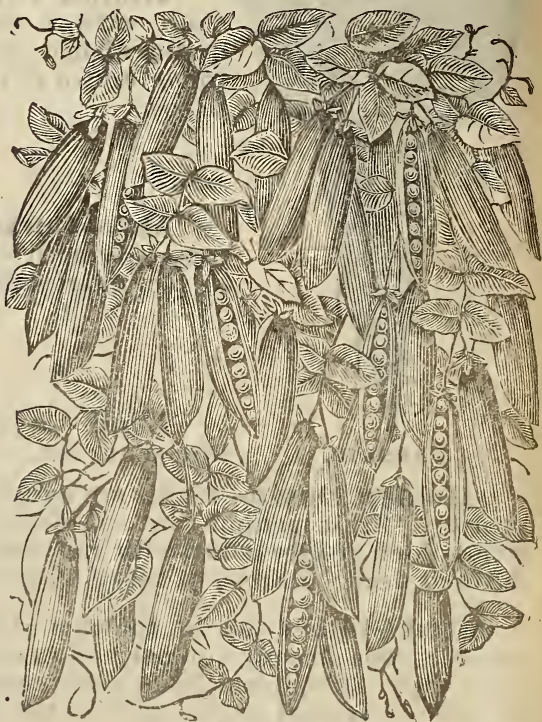

M'LEAN'S IITTLE, GEM. pods that the peas are always more square than round, a decided acquisition and sure to be very popular when generally known, Pkt 5c, half pint 1oc, pint 20c, quart $35 \mathrm{c}$.

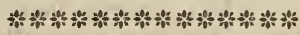




\section{SECOND EARLY.}

Telephone-This pea has proved to be a valuable acquisition. Vines large, with large, coarse leaves. Pods very large, filled with immense peas, which are sweet, and of excellent flavor. Notwithstanding the large amount of inferior and spurious stock that has been sold, no pea of recent introduction has gained more rapidly in popularity than this, thus showing that it has sterling merit which gardners appreciate. The stock we offer is prolific and has been carefully selected. Pkt 5c, half-pint Ioc, pint 20c, quart $35 \mathrm{c}$.

Pride of the Market-A popular strong-growing variety. Height eighteen to twenty inches, loaded with large, long pods, well filled with very large, exquisitely flavored peas. Of wonderful productiveness and superb quality. Pkt $5 \mathrm{c}$, half-pint Ioc. pint $20 \mathrm{c}$, quart $35 \mathrm{c}$.

B I is s Everbeariug-This new pea is a cross between the Little Gem and the Champion of Eng. land; height two feet foliage large, firm and bright green; pods three to four inches long, each pod producing from six to eight large wrinkled peas; its habit of growth is of peculiar branching character, forming as many as ten stalks from one root stalk. Pkt 5c, half-pint roc, pint $20 \mathrm{c}$, quart $35 \mathrm{c}$.

TELEPHONE.

French Canner-An enormously productive variety, best suited for the production of the small, dark green peas, which are tender and of delicate flavor when young, but becoming hard and tasteless when mature. Dry peas small, smooth and nearls white. Pkt $5 \mathrm{c}$, half-pint roc, pint $20 \mathrm{c}$, quart $35 \mathrm{c}$.

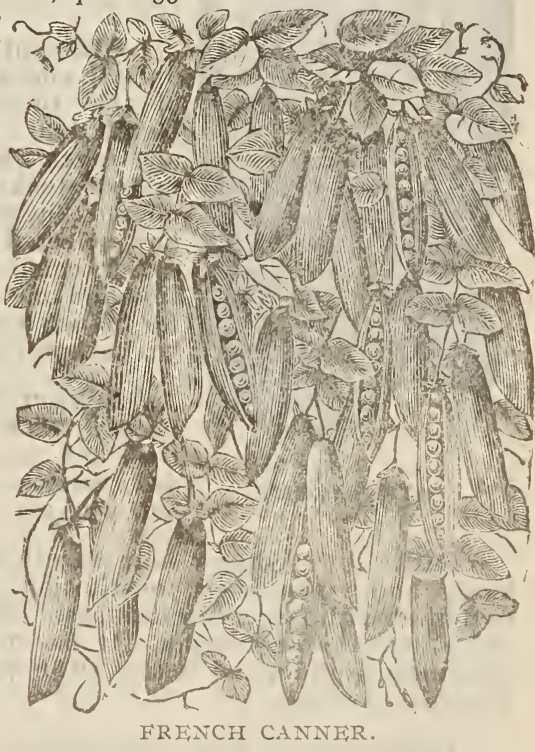




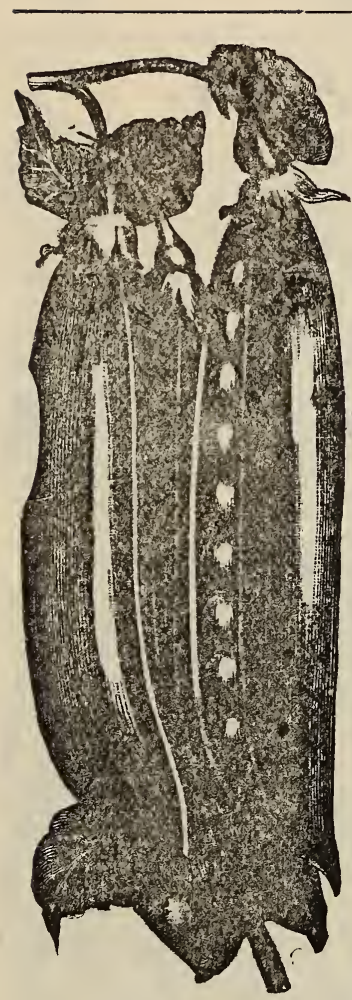

\section{Late Sorts.}

Improved Stratagem-A sort in which the good qualities which gave the old Strategem its popularity are so developed as to make it a distinct vari ety. We do not hesitate to pronounce this by far the best of the large-podded peas; the pods are of immense size, filled with very large, dark green peas of the finest quality; vine medium height but very stocky, with very broad, light green leaves, and bearing an abundance of large handsome pods. One of the very best varieties for market gardens. Pkt $5 \mathrm{c}$, halfpint Ioc, pint 20c, quart $35 \mathrm{c}$.

Champion of England-Very productive and universally admitted to be one of the richest and best flavored peas. Height four to five feet; seed whitish green and much shrivelled. Very inferior and mixed stocks of this sort are frequently offered, but when the seed is as well grown and selected as that we offer, we consider variety equal in quality to any in cultivation and one of the best of its season,either for the amateur or market gardener. $\mathrm{Pkt}$ 5c, half-pint Ioc, pint 20c, quart $35 \mathrm{c}$.

Dwarf Gray, Sugar - Edible pods. Of extraordinary yielding qualities, and unsurpassed as an edible pod-, STRATAGEM. ded variety. Height two feet. Pkt 5c half pint Ioc, pint 20 , quart $35 \mathrm{c}$.

Duke of Albany-An excellent new variety. remarkably hardy and vigorous in constitution, producing pods of good size, well filled with large, luscious peas. It is of hearty vigorous growth and a remarkable cropper. It has proven a valuable main crop sort, most proliflc, and best of all in quality.-Pkt $5 \mathrm{c}$, half-pint roc, pint 20c, quart $35 \mathrm{c}$.

Large Black Eye Marrowfat-An excellent variety, growing about five feet high; pods large; a prolific bearer, and can be recommended as one of the very best Marrowfat sorts. Pkt $5 \mathrm{c}$, halfpint Ioc, pint 20c, quart $35 \mathrm{c}$.

Tall Gray Sugar-An edible podded variety of good quality. It is very productive. The peas are eaten shelled also, and are very sweet. Plat $1 / 2$ pint Ioc, pint $20 \mathrm{c}$, quart $35 \mathrm{c}$.

\section{Pumpkins.}

Small Sugar--A particularly fine orange-colored sort, remarkably sweet, finegrained and dry. Keep well and cannot be beat for table use. Always gives the best satisfaction. Pkt $5 \mathrm{c}$, oz Ioc, 2 oz I5c, $1 / 41 \mathrm{lb} 20 \mathrm{c}, 1 \mathrm{~b} 6 \mathrm{oc}$.

Tonnessee Sweet Potato-One of the very best pie and cooking pumpkins. They grow pear-shaped, to a good size, slightly ribbed; skin is a cream white, flesh very thick, creamy white, dry and fine-grained, keeping well until late in the spring; when cooked resembles sweet potatoes, but more delicious in taste. The vines are hardy and enormously productive. Pkt $5 \mathrm{c}, \mathrm{oz}$ Ioc, $1 / 4 \mathrm{lb} 25 \mathrm{c}, 1 \mathrm{~b} 75 \mathrm{c}$. 
Large Cheese-A favorite for cooking, and also profitable for stock feeding, as the vines are very fruitful and the pumpkins quite large. Both the rind and the flesh are orange-colored, and the quality is excellent for cooking purposes. Pkt 5c, oz IOc, 2 oz I5c, quarter $1 \mathrm{~b} 20 \mathrm{c}, 1 \mathrm{~b} 60 \mathrm{c}$.

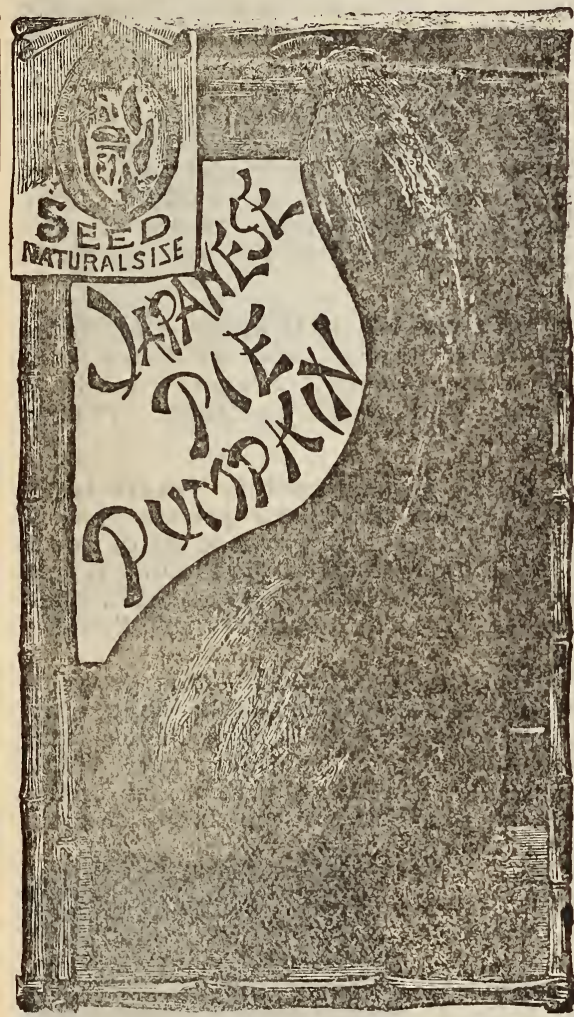

Japanese Pie Pumpkin-In form it resembles the Cushaw; the flesh is solid in the large neck, and but very small seed cavity in the large end; fine-grained, dry and sweet. They ripen early and keep well; the seeds are peculiarly sculptered. Pkt 5c, oz Ioc, quarter $1 \mathrm{~b} 20 \mathrm{c}, 1 \mathrm{~b} 60 \mathrm{c}$.

Nantucket, or Negro-Skin is dark green, almost black. Flesh thick and of a rich orange yellow, sweet, and weighs generally from ten to fifteen pounds each and will keep nearly a year. $\mathrm{Pkt} 5 \mathrm{c}, \mathrm{Oz}$ IOc, quarter $1 \mathrm{~b}$ 20c, $1 \mathrm{~b} 60 \mathrm{c}$.

Cushaw-A well known variety resembling the Winter Crookneck Squash in form. The flesh is salmon-colored and of good flavor; the rind light cream color, striped with green; fruit very large; vines productive. Pkt $5 \mathrm{c}, \mathrm{Oz}$ IOc, quarter $1 \mathrm{~b} 25 \mathrm{c}$, 1b $75 \mathrm{c}$.

\section{RADISHES,}

French Breakfast-A medium-sized radish, olive-shaped, small top, of quick growth, very crisp and tender, of a beautiful scarlet color, except near the tip, which is pure white. A splendid variety for the table, on account of its excellent quality and beautiful color. Pkt $5 \mathrm{c}, \mathrm{Oz}$ IOc, $2 \mathrm{oz}$ I5c, quarter $1 \mathrm{~b} 20 \mathrm{c}, 1 \mathrm{~b} 60 \mathrm{c}$.

Early Scarlet Turnip, White Tipped-One of the handsomest of the turnip radishes and a great favorite in many large markets for early planting out of doors. It is but little later than White Tipped, Forcing, and will give entire satisfaction where extreme earliness is not the primary object. Root slightly flattened on the under side, color very deed scarlet with a white tip; flesh white and of the best quality. Pkt $5 c$, oz IOc, 2 oz I5c, quarter $1 \mathrm{~b} 20 \mathrm{c}, 1 \mathrm{~b} 6 \mathrm{oc}$.

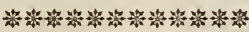

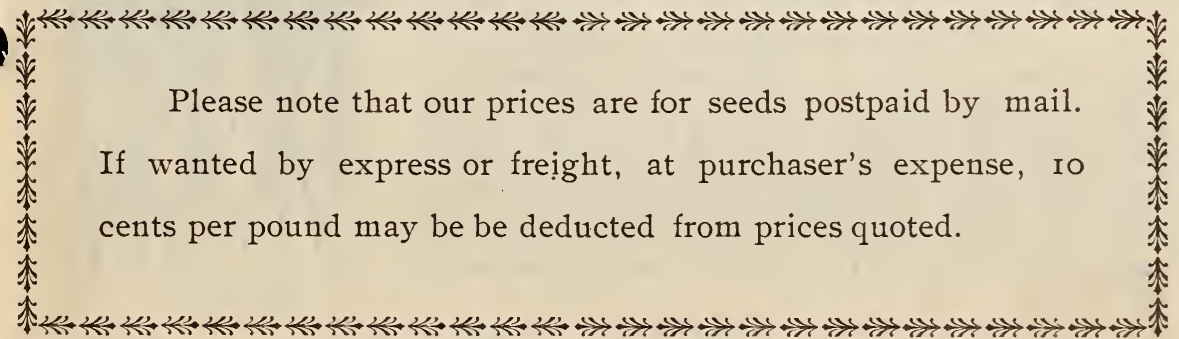




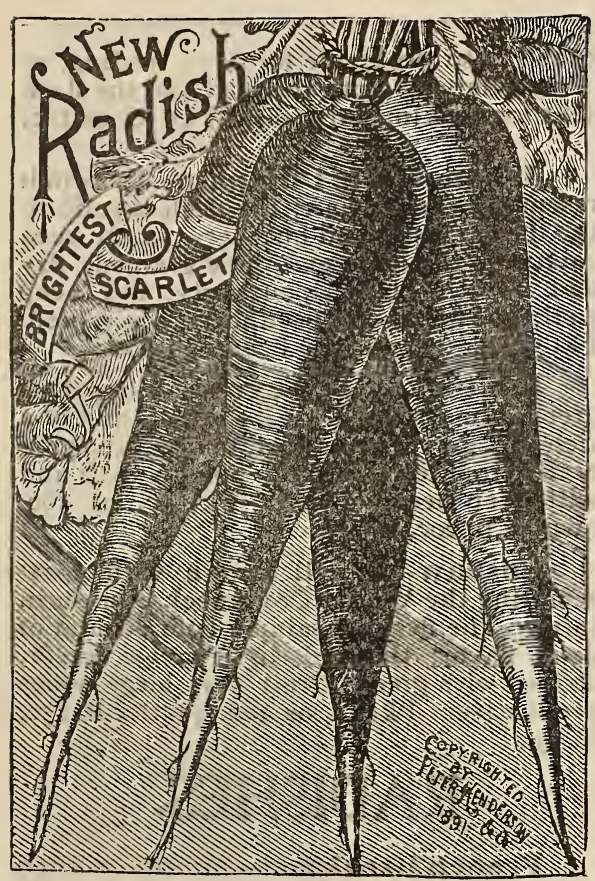

Longest Brightest Scarlet. White Tipped-This is the brightest and handsomest colored scarlet radish known, and a decided improvement in earliness and color over other varieties in this class. It makes roots fit for use in about twenty-five days from time of planting, and they continue in good condition until they are full grown, when they are as large as the Woods Early Frame. It has a small top and no tendency to neckiness. Market gardeners should use this for early planting, as its beautiful color will always attract attention, and its fine quality please all who buy it. Pkt 5c, oz IOc, 2 oz I5c, quarter $1 b$ 20c, $1 \mathrm{~b} 7 \mathrm{Oc}$.

Chinese Rose Winter-One of the best winter varieties; a beautiful rose color; flesh white, firm and of superior quality; a favorite with -market gardeners. $\mathrm{Pkt} 5 \mathrm{c}$, oz Ioc, $1 \mathrm{~b} 75 \mathrm{c}$.

Early Long Scarlet. Short topThe standard variety for private gardens and market use. It grows to six or seven inches long, half out of the ground; is very brittle and crisp; color bright scarlet, small top. Pkt 5c, oz ro, quarter $1 \mathrm{~b} 20 \mathrm{c}, 1 \mathrm{~b} 60 \mathrm{c}$.

White Strasburgh-This grows to the largest size and is usable when quite small, thus covering a long season. The

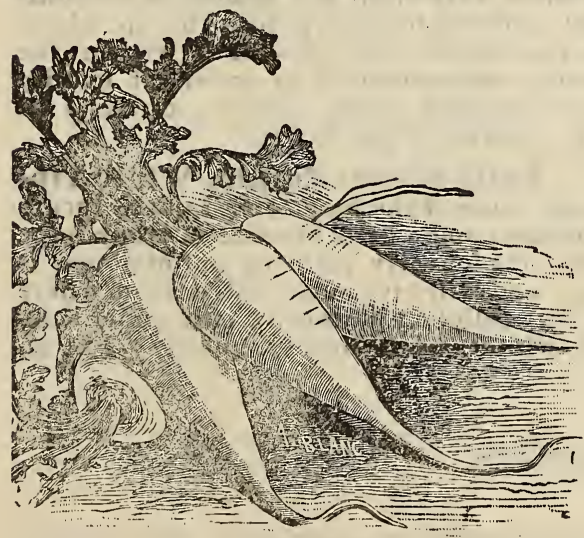

WHITE STRASBURGH. mature roots are four or five inches long and about two inches thick; very white; the flesh is exceedingly crisp and tender One of the best of the large summer sorts. Pkt $5 \mathrm{c}$ oz IOC, 2 oz I5c, quarter $1 \mathrm{~b} 20 \mathrm{c} 1 \mathrm{~b} 6 \mathrm{oc}$. Chartier,
or $\mathbf{S}$ e p h e r d-A 1 though this American va. riety is too strong growing to be used for forcing, it is one of the very best for growing out doors. $\mathrm{T} \mathrm{h}$ e roots come to usable size verv early, remaining hard and crisp until they reach a diameter of one and onehalf or two inches, and so furnish good roots two or three times as long as any of the preceding varieties. Roots scarlet rose above, shading into white at the tip. They are long, cylindrical for the upper two-thirds, and then gradually taper to the tip. Fresh white, crisp and mild-flavored. Pkt $5 \mathrm{c}$, oz $10 \mathrm{c}, 2 \mathrm{oz} \quad 15 \mathrm{c}$, quarter $1 \mathrm{~b}$ $20 \mathrm{c}, 1 \mathrm{~b} 6 \mathrm{oc}$.

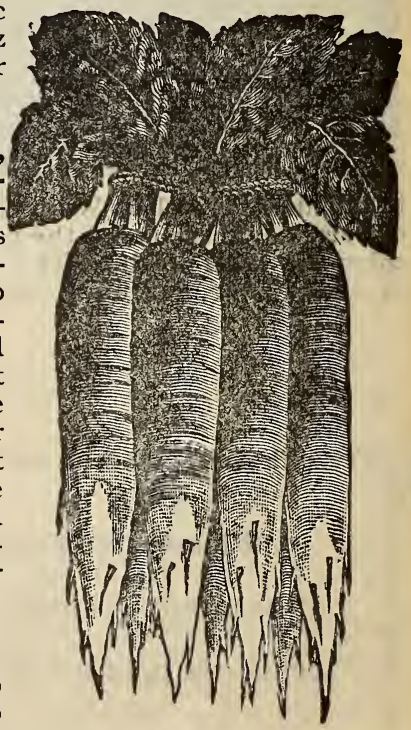

CHARTIER. 
Wood's Early Frame-Extensively grown by market gardeners for forcing. Similar in growth to the Long Scarlet, but about ten days earlier, and shorter. The radishes are a bright scarlet, blending to white at the bottom; crisp and tender. Pkt $5 c$, oz IOc, $1 / 41 \mathrm{~b} 20 \mathrm{c}, 1 \mathrm{~b} 65 \mathrm{c}$.

Vixes Scarlet Globe-This is unquestionably the earliest forcing radish extant. It grows very, rapidly and is fit for use within three weeks from time of sowing. The root is of fine round form, the color a bright scarlet, the flesh tender, and of particularly delicate flavor. It has a very short top, the leaves being very few and quite

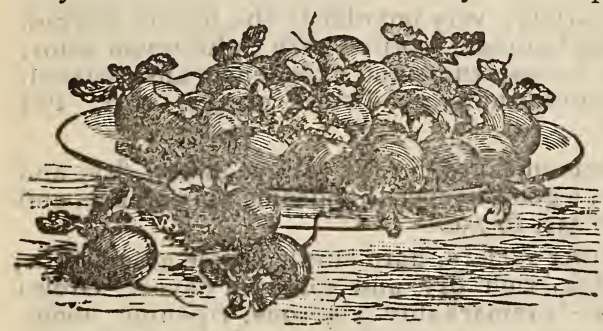

EARLY SCARLET TURNIP. small. Pkt. 5c, oz roc, $1 / 4$ lb 20c, $1 \mathrm{~b} 60 \mathrm{c}$.

Philadelphia White Box - Remarkably short top, rapid grower, fine quality, perfect turnip shape, sweet and juicy, long standing, good for forcing, a favorite with Philadelphia market gardeners. Pkt 5c, oz I5c, I 4 lb 20c, 1b 7oc.

Early Scarlet Turnip-A small, round, red, turnip-shaped radish, with small top and of quick growth. A very early variety, deserving general cultivation on account of its rich color and crisp, tender flesh. Desirable for forcing or early out-door planting. Pkt $5 \mathrm{c}, \mathrm{oz}$ IOc, quarter $1 \mathrm{~b} 20 \mathrm{c}, 1 \mathrm{~b} 65 \mathrm{c}$.

\section{RHUBARB „Pie Plant.}

Victoria-A large growing variety, one of the most popular with the gardeners. It makes a very broad stalk, comes very early in the spring. For home use it is best. Pkt $5 \mathrm{c}$, oz I $5 \mathrm{c}$.

\section{SALSIFY,}

Blue Flowered French-A good substitute for the oyster, which it closely resembles. Roots about a foot long and one inch in diameter, white and tapering. Pkt 5c, oz 20c, 1b $\$ 1.50$.

Mammoth Sandwich Island-This variety is a great improvement over the common variety, and is favored by market gardeners on account of its fine appearance. Pkt $5 \mathrm{c}, \mathrm{Oz} 20 \mathrm{c}, 1 \mathrm{~b} \$ \mathrm{I} .50$.

\section{Spinach.}

Prickly Winter-A very handsome variety, and will withstand the severest weather, with only a light protection of leaves and straw. The seed is prickly, the leave triangular and oblong or arrow-shaped. It is employed for fall sowing, which in this latitude is made about the first of September Pkt $5 \mathrm{c}$, oz Ioc quarter $1 \mathrm{~b}$ I5c, $1 \mathrm{~b} 35 \mathrm{c}$.

Thick Leaved Round-Produces large, thick, dark green leaves, somewhat crumple, and possesses the valuable quality of standing a long time. Pkt $5 \mathrm{c}, \mathrm{oz}$ IOc, quarter $1 \mathrm{~b}$ I5c, $1 \mathrm{~b} 35 \mathrm{c}-$

Savoy Leaved-The earliest variety and one of the best to plant in autumn for early spring use. Plant of upright growth, with narrow, pointed leaves, which are savoyed like those of cabbage. It grows quickly to a suitable size for use, but soon runs to seed. Pkt $5 \mathrm{c}$, oz Ioc quarter $1 \mathrm{~b} \mathrm{I}_{5} \mathrm{c}$.

\section{SQUASHES,}

Faxon-In color it differs from all other squashes. When ripe some are pale yellow, with paler stripes in hollows; others are green mottled. The flesh is deep orange yellow; has very small seed cavity. While uncooked it seems to have a hard shell,but after cooking there is practically none, the inedible part being only about as thick as a sheet of writting paper. It is sweet and very dry and nothing excels it for squash pies. Pkt $5 \mathrm{c}$, oz $\mathrm{I}_{5} \mathrm{c}$, quarter $1 \mathrm{~b} 25 \mathrm{c}, 1 \mathrm{~b} 75 \mathrm{c}$. 
Hubbard-This is a superior variety and the best winter squash known; flesh bright orange yellow, fine grained, very dry, sweet and rich flayored; keeps perfectly good throughout the winter; boils or bakes exceedingly dry and is esteemed by many to be as good baked as the sweet potato. We have taken the utmost pains with this sort, and can recommend our stock as in all probability the best in the country, and think our customers can plant it in perfect confidence that every plant will be a pure Hubbard. Pkt 5c, oz Ioc, quarter $1 \mathrm{~b} 20 \mathrm{c}, 1 \mathrm{~b} 60 \mathrm{c}$.

Boston Marrow-A fall and winter variety, very popular in the Boston market. Of oval form; skin thin, when ripe, bright orange, mottled with light cream color; flesh rich salmon yellow, one grained, and for sweetness and excellence unsurpassed, but not as dry as the Hubbard. We have an unusually good stock of this sort. Pkt $5 \mathrm{c}$, oz IOc, 2 oz I5c, quarter lb 20c, $1 \mathrm{~b} 75 \mathrm{c}$.

Fordhook-The earliest of the winter squashes, bright yellow, sweet, dry, and very thick meated, immensely productive, a good keeper, handsome appearance, and spendid quality. Pkt $5 \mathrm{c}$, oz Ioc. quarter $1 \mathrm{~b} 25 \mathrm{c}, 1 \mathrm{~b} 75 \mathrm{c}$.

Sibley or Pike's Peak-A very distinct variety, hard shelled, pale green, thin, and flinty; flesh brilliant orange, solid, thick, rich, dry, and splendid flavor. Grows to a moderate size-eight to eleven pounds-is remarkably vigorous; ripening about with the Hubbard. A splendid keeper,, retaining its fine flavor, and remaining perfectly solid until the last of March. Pkt 5c, oz Ioc, quarter 1b 20c, $1 \mathrm{~b} 75 \mathrm{c}$.

Summer Crookneck-A very fine summer variety, yellow fruit, early and productive. Pkt 5c, oz Ioc, quarter $1 \mathrm{~b} 20 \mathrm{c}, 1 \mathrm{~b} 50 \mathrm{c}$.

Perfect Gem-Fruit round, six to eight inches in diameter, and borne in clusters. Sheli exceedingly thin, smooth, ribbed, and creamy white. Flesh cream-colored, dry sweet and rich. Exceedingly desirable either as a summer or winter vaety. Pkt $5 \mathrm{c}, \mathrm{oz}$ IOc, quarter $1 \mathrm{~b} 20 \mathrm{c}$, 1b $50 \mathrm{oc}$.

Bay State-The shell is light green, hard and flinty, and is one of the longest keepers known. Flesh very thick, and solid, bright golden yellow, dry, fine-grained, flavor sweet and excellent, seed cavity very small. It matures very early, and can be planted as a second crop after early peas; if planted late it will escape the squash maggot and still ripen. Pkt 5c, oz roc, quarter $1 \mathrm{~b} 20 \mathrm{c}, 1 \mathrm{~b} 60 \mathrm{oc}$.

Winter Crookneck-Largely grown in some states. Sweet, fine flavored, hardy and a good keeper. Pkt 5c, oz roc, lb 6oc.

Cushaw Pie Squash-This is a genuine Cushaw, and is a great favorite wherever known for its many good qualities. It is very beautiful in appearance, being a distinct mottled green and white striped. Sells well on any market. Pkt $5 \mathrm{c}$, oz IOc, Ib 6oc.

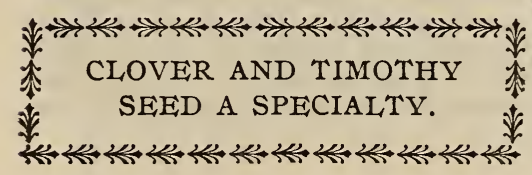

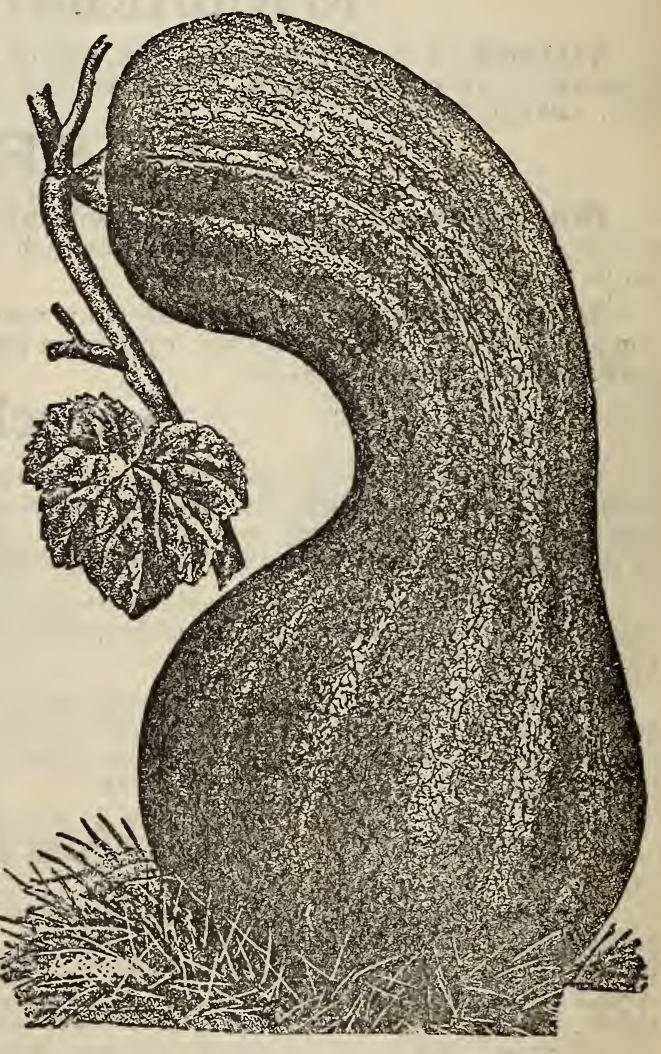

CUSHAW PIE SQUASH. 


\section{Rape.}

Dwarf Essex-(The Biennial variety.) The Essex is considered indispensible by the sheep, hog and cattle farmer of Great Britain, and is fast coming into use in this country on account of its rapid growth, being ready to feed within ten weeks from sowing, and producing twenty-five to thirty tons of green forage per acre. It grows to a height of three feet and covers the surface so densely as to smoother out all weeds and to kill quack and all other objectionable grasses. It can be sown all through the season, being perfectly hardy, withstand drought, and will produce a crop in any soil by sowing broadcast at the rate of five to to ten pounds per acre, or in drills or rows two feet apart at the rate of four or five pounds per acre. While unequaled for pasture for sheep, as a fattening food for all kinds of live stock it is without a rival in point of cheapness or ef-

DWARF ESSEX RAPE,

fectiveness. Any good corn soil will grow rape. A number of customers last year that were short of pasture sowed rape and oats in April. One farmer reported pasturing 325 sheep and lambs on thirteen acres of rape. It is fine hog pasture, and when sown with rye and oats makes an excellent pasture for cattle and young horses, but rape alone is like clover-will sometimes bloat cattle, but sown with oats, rye or barley there is no danger of bloating. Some farmers report sowing rape in the corn at the last plowing and claim it is very profitable pasture for sheep and lambs. Rape is especially adapted as a catch crop, as it is like turnips, will make a growth late in the fall and takes a freeze to kill it. When sown broadcast use five to ten pounds per acre, if in drills use four to five pounds per acre. We get our seed direct from Great Britain and can name you very low prices. Pkt Ioc, 1b, by mail, 25c. By freight or express, I2 lbs $\$ \mathrm{I}, 50 \mathrm{lbs} \$ 4$, roo lbs $\$ 7.50$. Rape weighs 50 pounds to the bushel.

\section{SUGAR CANE.}

Early Amber-This variety is successfully grown in our extreme northern latitudes. It may be planted as late as the $5^{\text {th }}$ of June, and will be ripe enough to manufacture in September. We know of no earlier variety. It is useless to plant cane seed before the weather is warm in spring. Three or four pounds are required per acre. By mail, postpaid, $1 \mathrm{~b} 25 \mathrm{c}, 3 \mathrm{lbs} 60 \mathrm{c}$; by express or freight, qt 20c, bu of $56 \mathrm{lbs}$, $\$ 2.00$, ro bu or over $\$ 1.75$ per bu.

Early Orange-An exceedingly valuable variety. Very large, of strong and vigorous habit; and does not fall down. It is early and yields more than any other sort, often producing as much as 240 gallons of very beautiful colored and highly flavosed syrup to the acre. We recommend it highly to all desiring a superior cane. By mail, postpaid; $1 \mathrm{~b} 25 \mathrm{c}, 3 \mathrm{lbs}$ $60 c$; by express or freight, qt 20c, bu of $56 \mathrm{lbs}$ $\$ 2.00$, Io bu or over $\$ 1.75$ per bu.

\section{TOBACCO.}

Connecticut Seed Leaf-Best adapted to the climate of the middle and northern states, as it is more hardy and endures the cold better than the tender varieties grown south. In many of the northern states and in Canada this variety is the stable crop. Pkt $5 \mathrm{c}$, oz 2oc, quarter lb $60 \mathrm{c}, 1 \mathrm{~b} \$ 2.00$.

Havana-This tobacco is the genuine article and is first-class. Pkt $5 \mathrm{c}, \mathrm{Oz} 20 \mathrm{c}$; quarter lb 5oc, $1 \mathrm{~b} \$ 2.00$.

White Burley-This variety is especially valuable to manufacturers either for cut

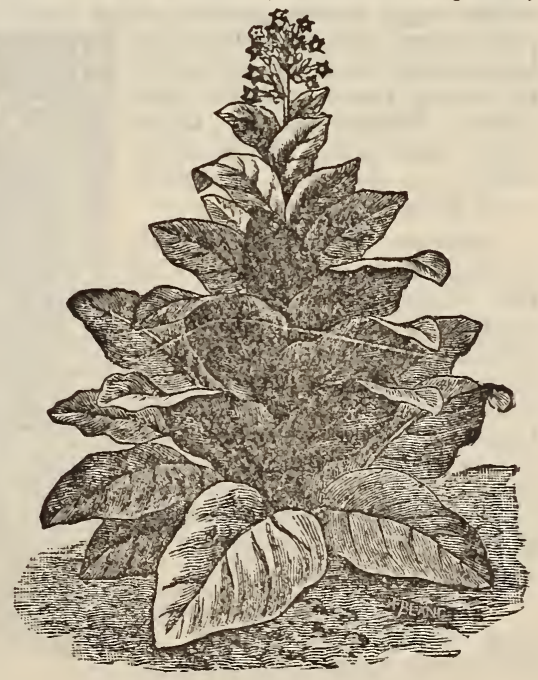

CONNECTICUT SEED LEAF. 
or plug tobacco. It is sometimes used for wrappers. Pkt $5 \mathrm{c}$, oz $30 \mathrm{c}, 2 \mathrm{oz} 5 \mathrm{oc}$, quar-

1b $\$ 1.00,1 b \$ 3.00$.

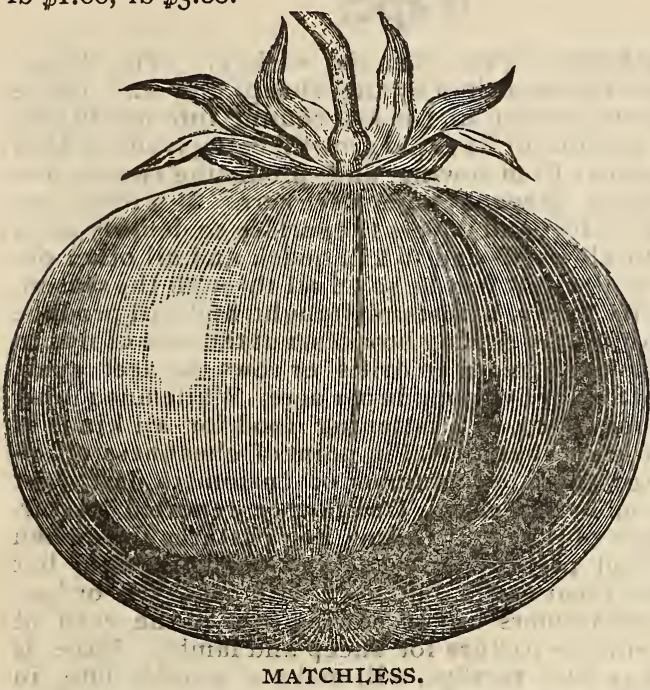

\section{TOMATOES,}

Matchless-Well worthy of its name. In beauty of color and symmetrical form it is without a peer. Very beautiful and extremely desirable. They are entirely free from core, of a rich cardinal red color. Not liable to crack or rot from wet weather. Pkt 5c, oz 25c, quarter $1 \mathrm{~b} 75 \mathrm{c}$.

Dwarf Champion-This is a purple fruited variety, which forms very stout, strong plants about two feet high. The branches are short, making a bushy plant that stands quite erect without stakes. This sort is often sold as Tree Tomato. Fruit smooth, medium size; color purplish-pink. fairly solid, but has no hard core, and is of good flavor. About as early as any purple-fruited tomato, and is quite popular in some localities, both for market and home use. The dwarf habit of the vines makes it very desirable for forcing, as it can be planted closer to the glass, and more closely on the bench than the tall growing kinds. Our stock is of a very superior strain, with larger, smoother fruit than the original. Pkt $5 \mathrm{C}, \mathrm{oz} 25 \mathrm{C}, 2 \mathrm{oz} 4 \mathrm{OC}$, quarter $1 \mathrm{~b} 75 \mathrm{c}, 1 \mathrm{~b} \$ 2.25$.

Perfection-This is one of the handsomest tomatoes grown, and all who have tried its invariably round, smooth, handsome, red fruit pronounce it of the highest quality. It has been used very satifactorily for forcing under glass. Pkt $5 \mathrm{c}, \mathrm{oz} 20 \mathrm{c}$, 2 oz 35 c, quarter $1 \mathrm{~b} 5 \mathrm{oc}, 1 \mathrm{~b} \$ 2.00$.

Mikado, or Turner's Hybrid-A very large fruited purple tomato, weighing as high as twenty-eight ounces, while the average weight is probably not less than twelve. Vines large, coarse growing, with leaves entire, iike those of the potato plant; very productive, and is early for so large a tomato, fruit extremely large, rough, solid, with seeds. Demanded by those who want extra large fruit. Pkt $5 \mathrm{c}$, oz $30 \mathrm{c}, 2$ oz $55 \mathrm{c}$, quarter $1 \mathrm{~b} \$ 1.00,1 \mathrm{~b} \$ 2.25$.

Stone-This is the heaviest and most solid fruited of the large tomatoes of good quality. Our stock is distinctly superior to most of that offered under this name, being more uniform, beter colored and larger. Vines vigorous and productive. Fruit round, apple shaped, very large, very deep red in color and astonishingly heavy. Pkt $5 \mathrm{c}, \mathrm{oz} 25 \mathrm{c}, 2 \mathrm{oz}$ $40 \mathrm{c}$, quarter $1 \mathrm{~b} 75 \mathrm{c}, 1 \mathrm{~b} \$ 2.25$.

Acme-Very large hardy and productive, ripening its first fruit almost as early as

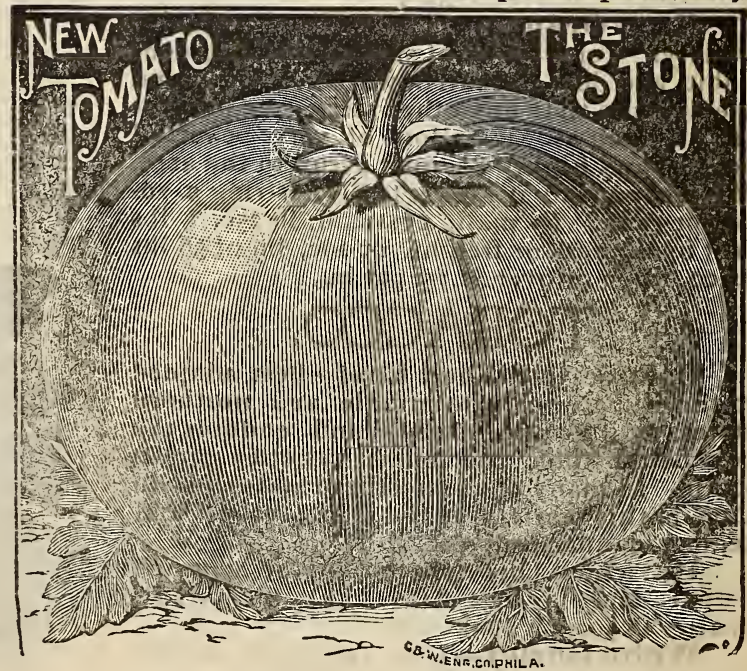


any, and continuing to bear abundantly until cut off by frost. Fruit in clusters of four or five, invariably round, smooth and of good size, free from cracks, and stands shipment remarkably well; flesh solid, and of excellent flavor. For market gardeners who wa - an early purple-fruited tomato, either for home market or to ship, for private $\mathrm{ga}_{\mathrm{i}}^{-} \mathrm{ns}$ or for canners, it stands without a peer among its class. The variety is used fo. planting under glass. Pkt 5c, oz 2oc, 2 oz 35c, $1 / 41 \mathrm{~b} 65 \mathrm{c}, 1 \mathrm{~b} \$ 2.00$.

Be uty-We have been selecting this to a larger, smoother fruit than the original sto $\therefore$, and think we have made it the smoothest and best of the large purple sorts. Vine latee, vigorous and heavy bearers; fruit large, uniform in size, very smooth; color of skin rrplish-pink; flesh light pink and of excellent flavor. While we think the color wak for canning, it is used considerably for that purpose. Pkt $5 \mathrm{c}, \mathrm{oz} 2 \mathrm{oc}$, quarter $1 \mathrm{~b} 60 \mathrm{c}$.

The PonderosaThis is the largest and heaviest tomato. The specimens that competed for the prize when this tomato was first i n $\mathrm{t} r$ o d u c e d weighed on the average one pound and six ounces. The Ponderosa possesses every good quality to be found in a tomato. The vines are strong and vigorous, and easily carry their enormous weight. Its massive, ponderous fruits are of good form and free from corrugations. $\mathrm{Th}$ e color is a rich crim.

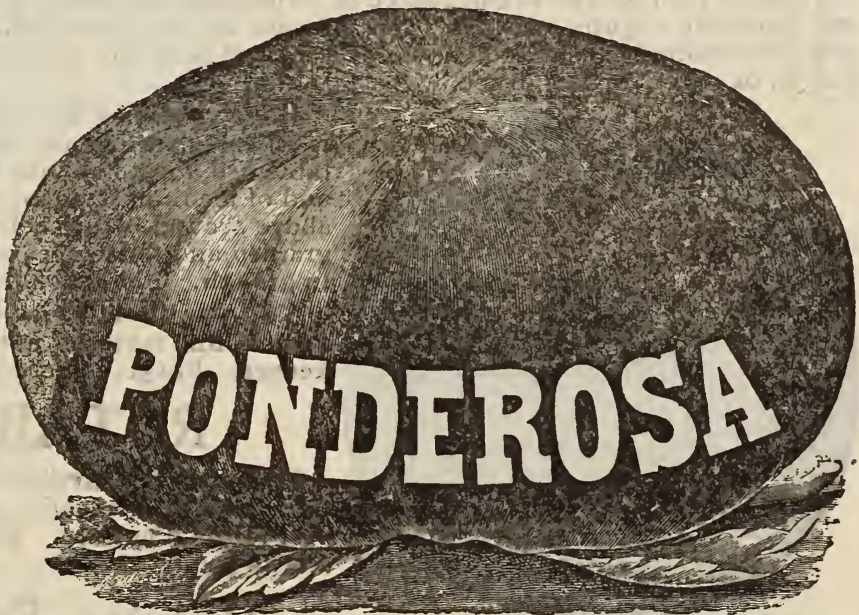

son. It is a good tomato for the canner or for home use. For slicing it is one of the best. All should give it a trial, It is no longer a novelty but is a specialty of merit. Pkt $5 \mathrm{c}$, oz $30 \mathrm{c}$, quarter $1 \mathrm{~b} 75 \mathrm{c}$.

Optimus-The best tomato, at least so far as quality is concerned. Vine medium size, but vigorous, healthy, productive. Although not represented as a first-early variety, many of our customers report that they have obtained ripe fruit from this as early as any variety. Fruit medium size, oval, very smooth and exceedingly bright, crimson-scarlet color, very free from cracks and never rotting. The flesh is of a crimson-scarlet color, and quite distinct. Pkt 5c, oz 20c, quarter $1 \mathrm{~b} 60 \mathrm{c}$.

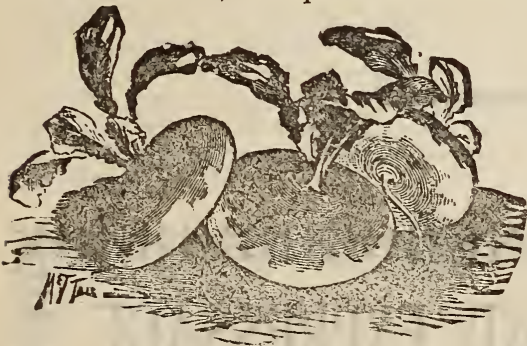

\section{Turnips,}

Extra Farly Purple Top Milan-The most desirable turnip for forcing, or very early planting out doors. Tops are very small distinctly strap-leaved, and growing very erect and compact. The roots are small and flat turnip-shaped; skin purple on top the root and white below; flesh clear white. Pkt $5 \mathrm{c}$, oz IOc, 2 oz I 5 c, quarter $1 \mathrm{~b} 25 \mathrm{c}, 1 \mathrm{~b} 5 \mathrm{Oc}$.

Orange Jelly, or Robertson's Golden PURPLE TOP MILAN.

Ball-Undoubtedly among the most delicate and sweetest yellow fleshed turnip yet introdued. Not of large size, but firm, hard, and of most excellent flavor. Keeps well and is superior as a table variety. It is well thought of in the south. Pkt $5 \mathrm{c}, \mathrm{oz}$ Ioc, $2 \mathrm{oz}$ I $5 \mathrm{c}$, quarter $1 \mathrm{~b} 20 \mathrm{c}, 1 \mathrm{~b} 50 \mathrm{c}$.

White Egg-A quick-growing, egg-shaped, perfectly smooth, pure white variety, growing half out of the ground, with small top and rough leaves. The flesh is very 
sweet, firm and mild, never having the rank, strong taste of some white varieties. Pkt $5 \mathrm{c}, \mathrm{oz}$ roc, quarter $1 \mathrm{~b} 20 \mathrm{c}, 1 \mathrm{~b} 5 \mathrm{oc}$.

Purple TopWhite Globe-Avariety of the purple top flat turnip,from which it originated. It is globular in form, and nearly as large as the Pomeranean White Globe, of beautiful appearance and of most excellent quality. Equally desirable for table or stock. It keeps well, and is a fine market sort. Pkt $5 \mathrm{c}, \mathrm{oz} 10 \mathrm{c}, 1 / 4 \mathrm{lb} 20 \mathrm{c}, 1 \mathrm{~b} 60 \mathrm{c}$.

Early White Flat Dutch-An early, white-fleshed,strap-leaved variety, usually sown very early in the spring; of quick growth, mild flavor and excellent quality, also grown for a fall crop. Pkt 5c, oz Ioc, 1/4 lb 20c, $1 \mathrm{~b} 60 \mathrm{c}$.

Cow Horn, or Long White-This variety is pure white, except a little shade of green at the top, and is carrot-like in form, growing nearly half out of the ground, and generally slightly crooked. It is delicate and well flavored, of very rapid growth and has obtained considerable favor as a market sort for fall and early winter use. $\mathrm{Pkt} 5 \mathrm{c}, \mathrm{Oz}$ IOc, $1 / 4 \mathrm{lb} 20 \mathrm{c}, 1 \mathrm{~b} 50 \mathrm{c}$.

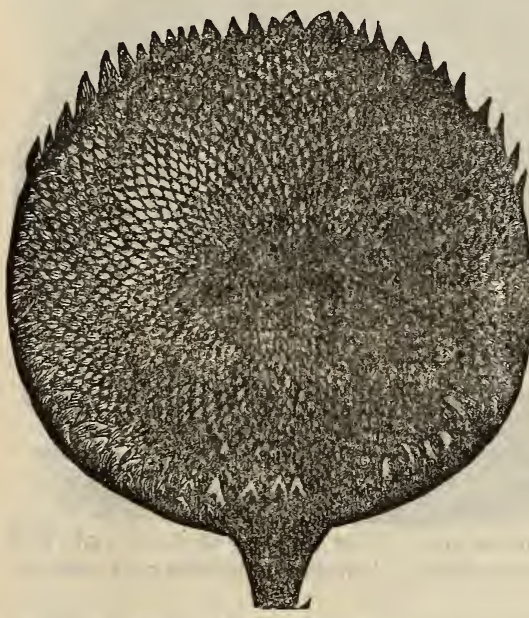

RUSSIAN SUNFLOWER.
Early Purplo Top-(Strap Leaved) This is an early variety and a great favorite for table use, form flat, like a broad disc in shape and of medium size; color purple or dark red above ground, white below, flesh white, finegrained and tender; leaves few, entire, upright in growth. Pkt $5 \mathrm{c}, \mathrm{oz}$ IOc, $1 / 4 \mathrm{lb} \mathrm{20c,1b} 60 \mathrm{c}$.

Yellow Abrrdeen-Of round form, yellow flesh of fine texture, nutritious, and a good keeper. Pkt 5c, oz Ioc, $1 / 4$ lb 20c, $1 \mathrm{~b} 5$ oc.

\section{RUTABAGA.}

Shirving's Purple-Enormously productive; flesh yellow, solid, sweet and one of the best for field culture. Pkt $5 \mathrm{c}$, oz Ioc, $1 / 41 \mathrm{~b}$ 2oc, $1 \mathrm{~b} 5 \mathrm{oc}$.

\section{Russian Sunflower.}

This is highly prized by poultry raisers and farmers as a cheap food for fowls. It is immensely productive, and can be raised cheaper than corn, as any waste piece of ground will suffice. It is the best egg producing food known. Oz 5c, $1 / 4 \mathrm{lb}$ Ioc, $1 \mathrm{~b} 20 \mathrm{c}$, prepaid. Not prepaid, Io $1 \mathrm{bs} 75 \mathrm{c}, 251 \mathrm{bs} \$ 1.25$, I00 pounds $\$ 4.00$. 


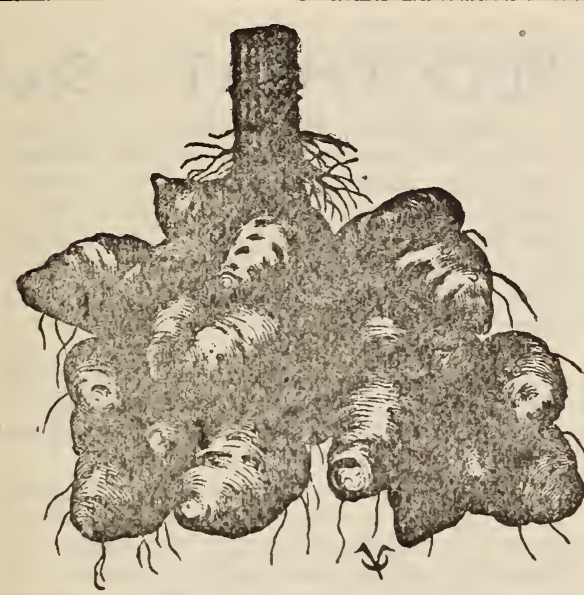

JERUSALEM ARTICHOKES.

\section{ARTICHOKES,}

Jerusalem-The greatest hog food known. Is, without quention, the greatest hog fattener in the world. I cannot too strongly urge upon every farmer to plant an acre or more this spring. They are attracting wide spread attention on account of their great fattening properties, and the ease with which they can be grown. They may not be dug in the fall. The hogs can be turned in on them and will keep themselves by rooting. They are also an excellent food for cattle sheep and horses. Well adapted to any soil where corn and potatoes can be grown. The yields are enormous, from 600 to r, 000 bushels per acre; plant in rows same as potatoes, coverabout two inches deep. They are not injured by freezing. I cannot urge you too strongly to buy at once, as the supply is limited. Half bu $75 \mathrm{c}$, bu $\$ 1.00$, bb1 $\$ 2.00$.

\section{Pop Corn.}

Queen's Golden-One of the very best and most prolific varieties grown. Its quality and handsome appearance when popped are very noticeable. It pops perfectly white. and a single kernel will expand to a diameter of nearly one inch. The stalks grow six feet high, and the large ears are produced in abundance. Pkt 5c, half-pint I $_{5} \mathrm{c}$, pint 20c, quart $35 \mathrm{c}$, by mail.

White Pearl-This variety, the ears of which are from six to eight inches in length, is the largest and most productive of this class of corn. Kernels large, rich color, twelve rowed. Pkt 5c, pint 20c, quart $35 \mathrm{c}$, postage paid.

White Rice-A very fine, white variety, ears from four to five inches in length and one to one-quarter in diameter. Kernels clear white, long and pointed at the top, sloping toward tip of ear. Not easy to husk but quite prolific, and especially saleable among the retail grocers. It is very desirable for family use, popping out very large and tender. Pkt $5 \mathrm{c}$, pint 20c, quart $35 \mathrm{c}$, postage paid.

\section{BARLEY.}

Mansury Spring-A six-rowed barley with long, heavy, well-filled heads, containing large, plump graines. Straw bright, very strong, and is not apt to lodge even on the richest lands. Express or freight, pk 40c, bu $\$ 1.00$; by mail, lb $20 c$.

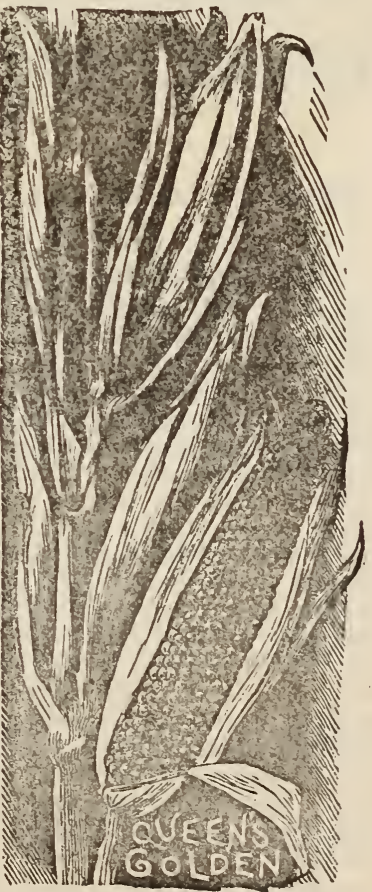

Success. The earliest barley known. Strong stiff straw, will stand up on any land. Has yielded 80 bu. per acre. The great beauty of this variety is that it is BEARDLESS, as easy to handle as oats. By mail, $1 \mathrm{~b} 20 \mathrm{c}, 3 \mathrm{lbs} 50 \mathrm{c}$ bu $\$ \mathrm{r} .00$. 


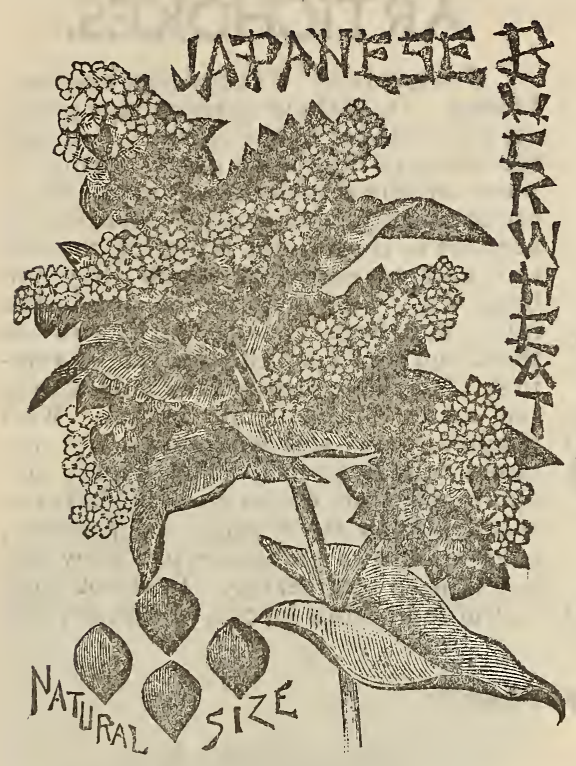

\section{BUCKWHEAT»„Seed}

Japanese Buckwheat-The kernels are at least twice the size of those of any other variety, and of a shape peculiar and distinct from all others. The color of the kernels is almost distinct, being a rich, dark shade of brown. The straw is heavier, very branchy and does not need to be sown as thickly as other kinds. The quality is excellent and the yield is enormous. It is about one week earlier than the Silver Hull. Pkt $40 c$, bu $\$$ r.oo, sack of two and one-half bu $\$ 2.25$. By mail, pkt Ioc, 1b 2oc, 3 lbs $50 \mathrm{c}$.

Silver Hull-This variety continues to bloom longer than common buckwheat, and is, therefore, better for bees. The flour is whiter and husks thinner. Pkt 4 oc, bu $\$ \mathrm{I} .00$, sack of $2 \mathrm{x} / 2$ bu $\$ 2.25$; by mail, pkt Ioc, $1 \mathrm{~b}$ 20c, 3 lb $50 \mathrm{c}$.

\section{BROOM CORN,}

Improved Evergreen-The best for general cultivation; bushes firm, of good length, and a bright green color. By mail, 3 oc per pound; 3 lbs $75 \mathrm{c}$, postpaid; bu $\$ 2.50,2$ bu $\$ 4.50$.

\section{CLOVER SEED.}

\section{Wish to Call Special Attention to Clover and Timothy Seed, as This is My Big Specialty.}

It is claimed that we produce more clover seed in this county than any other in the state. My facilities for handling clover seed are first-class in every particular. I have an elevator built especially for handling seeds, equipped with a ten horse power gas engine and fitted with the latest improved cleaning machinery; large bins for the various kinds and grades of seed. Each bag is carefully inspected on arrival and the different grades are placed in separate bins. The Mammoth Clover seed is always kept separate from the Red Clover. It is our aim to make highest quality a first consideration and then make our prices as low as good, honest seeds can be sold by any one. I wish to call your attention to our choice seed, which has no superior in quality; made up of all perfect grains and each and every grain will surely germinate and insure good crops if given the proper chance-sown in season when the soil is in proper condition. to receive the seed. You may be able to buy cheaper seed elsewhere. There is no telling how many dozen different kinds of weeds and wild mustard you will get in such cheap seed-many of which are not discernable with the naked eye. We urge, therefore, upon every customer the advisability of purchasing our choice clover and timothy seed, and thereby getting the best that the earth produces. I will gladly mail you sample to test for yourself upon receipt of four cents postage, and you can deduct the four cents when you place your order.

Our shipping facilities are first-class. We have two good railroads, the C. C. C. \& St. L. (Big Four) and the Chicago \& South-Eastern. We have two express offices, the American and United States. We are located twenty-eight miles northwest of Indianapolis, in Lebanon, "The Garden Spot of Indiana."

When ordering your clover and timothy seed, please include your garden seed, as my prices will be found as low as anyone that will sell you first-class seed.

To my customers I feel grateful for their patronage. From those who never dealt with us we ask a trial order. 
Mammoth-Mammoth Clover, known as English Sapling and Pea Vine, grows five or six feet high, lasts longer than most varieties. It will often grow where other clover fails and is often used for plowing under in exhausted lands. Sow in spring or fall at the rate of ten pounds per acre. Sixty pounds per bushel. Lb 20c, postpaid. Choice, $\$$ bu; prime, $\$$ bu.

Medium Red, or June-This is the common red clover in general cultivation, the most important variety for practical purposes sown. When sown alone produces hay of excellent quality, and when sown with other grasses forms a desireable pasture. It is regarded as one of the very best vegetable fertilizers, Sow in the spring or fall at the rate of ten pounds per acre. Sixty pounds per bushel. Pound 20c, postpaid. Choice, $\$$ bu; prime, $\$$ bu.

Alsiko-Alsike, or Swedish Clover, is very valuable for pasturage and very productive, is sweet and fragrant and much liked by bees. It is the most hardy of all clovers, yields an enormous quantity of hay or pasture and can be cut several times in one season. Sow in the spring or fall at the rate of six pounds per acre; 60 pounds per bushe1. Ask for prices.

White Dutch-A small, creeping, spreading, perennial variety, valuable for pasture and lawns. It accommodates itself to a variety of soils, but prefers moist gronnd. In conjunction with blue grass it forms a most nutritious food for sheep or cows. Sow in spring at the rate of six pounds per acre, or when used with other grasses half the amount will be sufficient. Lb 40c, 3 lbs $\$ 1.00$, postpaid; bu $\$ 12.00$.

Alfalfa, or Lucerine-One of the best varieties, succeeding in almost every situation and bearing heavy crops of forage. Will bear cutting three or four times during the season. For bringing up poor land it is the best of the clover, as it not only produces large masses of foilage, but forces its roots down fully three feet into the earth. Sow early in the spring to secure a good stand before winter if to be used for pasture or for curing. Lb $30 \mathrm{c}$, postpaid; rolbs, express, $\$ 2.00$; bu $\$ 6.00$. Good new bags, holding $2 \frac{1}{2}$ bushels of clover or Timothy seed, will be furnished at $15 \mathrm{c}$ each.

\section{TIMOTHY.}

TIMOTHY-Well known and extensively grown in all parts of the country. There is no variety of grass which has come into prominence so much of late years as Timothy. It is the most valuable of all grasses for hay, especially in the north. Farmers are beginning to recognize the fact that there is money in raising Timothy, whether for hay or seed. It thrives best on moist, loamy soils, and produces very heavy crops. Horses are especially fond of this grass. It posesses a larger amount of nutritive matter than most grass and yields abundantly ou favorable soil. Sow early in the spring or fall at the rate of Io or I2 lbs per acre if alone, but less if mixed with other grasses. Our seed, as usual, is very fine, and it will pay you to give it a trial; 45 pounds per bushel. Ask for prices.

Kentucky Blue Grass, Fancy Clean-Sometimes called June. Kentucky Blue Grass is the most nutritious, hardy and valuable of all modern grasses. In connection with white clover it makes a splendid lawn; for this purpose, use four bushels of blue grass and six pounds of white clover per acre. If sown by itself for pasturage about 28 pounds per acre will be required. Sow early in the spring or in October or November; I4 lbs bu. Fancy clean seed $20 \mathrm{c} \mathrm{1b}$, postpaid; per bu $\$ 1.40$.

Orchard Grass-This is one of the most valuable and widely known of all pasture grasses, coming earlier in the spring and remaining later in the autumn than any other. It grows about two and a half feethigh, producing an immense amount of leaves and foliage. Blooms with red clover and makes with it admirable hay. It is well adapted for sowing under trees or orchards, and very valuable either for grazing or hay; $\mathrm{r}_{4} \mathrm{lbs}$ bu, 2 bu acre. Lb $20 \mathrm{c}$ postpaid; bu $\$ 1.50$.

Red Top-A valuable grass for moist soils and low lands. It is a good permanent grass, standing our climate as well as any other, and consequently well suited to our pastures, in which it should be fed close, for if allowed to grow up to seed the cattle refuse it. On moist, rich soil it will grow two feet, and on poor, gravelly soil about half that hieght; $14 \mathrm{lbs}$ bu, 2 bu to acre. Lb 20c, postpaid; bu $\$ \mathrm{I} .50$. 
German, or Golden Millett-An improved variety, medium early, growing three to five feet high. The heads are closely condensed, though the spikes are very numerous. The seeds are contained in rough, bristly sheaves and are round, golden yellow and beantiful in appearance. Lb 20c, by mail; bu $85 \mathrm{c}$.

Hungarian-This is a species of annual millett, growing less rank, with smaller stalks, often yielding two or three tons per acre. It is very popular and valuable with those who are clearing timber lands. Sow and cultivate like millet. Lb 20c, by mail; bu 85 c.

\section{Field Peas,}

Each year there is a large increase in the number of our best farmers who sow field peas, and they claim that they are one of the most profitable crops for fattening stock, and especially for hogs. Stock eats them with great avidity. Also profitable for marketing as dry or split peas. Sow two bushels to the acre; if with oats one bushel of each. We offer two varieties as follows:

C. White Canada-More used than any other. Pkt $40 \mathrm{c}$, bu $\$ 1.40,2$ bu or more at $\$ 1.35$ per bu.

Blue or Green-Like above, except that color is bluish green. Pk 40c, bu $\$ 1.40,2$ bu or more $\$$ r.35 per bu.

Cow Peas-The greatest soil improver. Makes poor land rich. Makes good land more productive. Also makes a splendid and nutritious green forage or hay crop, enriching the soil even when the crop is cut off. Leguminous crops plowed under are one of best and cheapest ways of improving the soil. For this purpose the Cow Pea has no superior, especially for medium or light soils. For this class of soils the Cow Pea is superior to clover as a soil improver; it also makes a splendid green food or a most nutritious hay. There is no surer or cheaper means of improving poor soil than by sowing Cow Peas, and if we consider that land improved by the use of clover takes eight months at least, while this, a much heavier crop is produced in three or four months, their great value is obvious to all. In its capacity as a nitrogen gatherer its growth largely enables the farmer to dispense with the use of nitrogen or ammoniate fertilizers. Nitrogen or ammonia as commercial fertilizers is valued at fifteen cents per pound. The Cow Pea, to the greater extent than other leguminous crops, has the power tn extract this costly nitrogen or ammonia from the 'atmosphere. To grow for hay they are most valuable, as they yield an immense quantity of feed of the best quality, and produce the crop in so short a time.

Cow Peas should be sown in May or June at the rate of about one and one-half bushels per acre. The best variety is the BLACK AND CLAY COW PEA. By mail, 1b 20c, 3 lbs $50 \mathrm{c}$, bu $\$ 2.00$.

\section{Potatoes,}

Our crop of potatoes was almost a failure here last season. I will have a complete assortment of seed potatoes some time in February, plenty early for their season's planting. I will have all the leading home and Michigan varieties.

\section{FIELD CORN,}

Improved Leaming-A popular variety which has given general satisfaction all through the United States. A strong and vigorous grower, stalks heavy and leafy, often bearing two fine ears. In color a rich yellow, grains deep and solid, set a small cob. Thousands of our best farmers think it is the best corn that grows. It has been planted for forty years and has never failed. It is a corn that will be planted for all time to come; it always matures and neverhas any chaffy corn; can be planted anywhere in the United States. Pk 30c, half bu 6oc, bu $\$ 1.00$; sacks 15 c, Io bu or more, sacks free.

Riley's Favorite Yellow Dent Field Corn-The peculiar point of merit or excellence that is claimed for it is its superior feeding quality and the great amount of shell corn to cob. The cob to Riley's Favorite is so small that it quickly dries out and leaves the germ sound and sweet. In short, we are fully convinced 
that if its merits were known by all corn growers, there would be such a demand for seed that no one county in the famous corn state of Indiana could supply the demand. Every corn grower should get enough to plant one field or more, and thus get a variety of corn that will increase his crop and correspondingly increase his profit. A few dollars invested in Riley's Favorite Yellow Dent seed corn will bring a larger dividend than farming usually returns. $\mathrm{Pk} 30 \mathrm{c}$, half bu $60 \mathrm{c}$, bu $\$ 1.00$, sacks $\mathrm{I}_{5} \mathrm{c}$, Io bu or more sacks free.

Boone County White-This is one of the best white corns that we have any knowledge of. It is a pure white corn, all white cobs, grains deep, thick and meaty, well filled out over butt and tip of ear, ears long and uniform from butt to tip; stalks of medium height, thick and strong, seldom ever blows down, is remarkably yieldy. It is regarded here by millers to be the best bread corn in the country. If planted properly it will nearly all be. large ears, no chaffy corn. $\mathrm{Pk} 30 \mathrm{O}$, half-bu 5oc, bu $\$ 1.00$; sacks 15 c; ro bu or more, sacks free.

Dungan's White Prolific-This is a remarkably fine, large white corn. It has been improved and brought into its present high standard by a careful system of scientific culture. It is a medium early variety and exceedingly prolific. It is perfectly pure white, all white cobs. $\mathrm{Pk} 30 \mathrm{c}$, half-bu 6oc; Io bu or more. sacks free.

Silvermine Oats-In I896 I purchased a quantity of the celebrated Silvermine White Oats of the John A. Salzer Seed Co., of La Cross, Wis. They proved to be all right and have made the largest yield of any variety of oats grown here. They are without a blemish, without a fault or flaw, grow 4 to 5 feet tall, straw stiff and don't fall down, and always yield heavily. You will make no mistake in sowing one or more fields with this magnificent oat. Bu 5oc, 5 or more bu bags free.

July Oats - Oftentimes the only crop that is saved entire and in good condition is the early one. No crop is more susceptible to damage by bad weather than the oat crop. Therefore, the earlier the variety, the less danger of damage and the more valuable, providing hardiness, yield and quality are not sacrificed.

In the July Oats we have the earliest variety combined with other good qalities, making it of peculiar and immense value to farmers. These oats ripen in this latitude about July 4 th, about two weeks ahead of other sorts. The straw is strong, medium tall heads, medium length; very compact, but contain many grains. The grains are white, plump and heavy, weighing 40 pounds to the bushel in good clean crops. Bu $50 c, 5$ or more bu bags free.

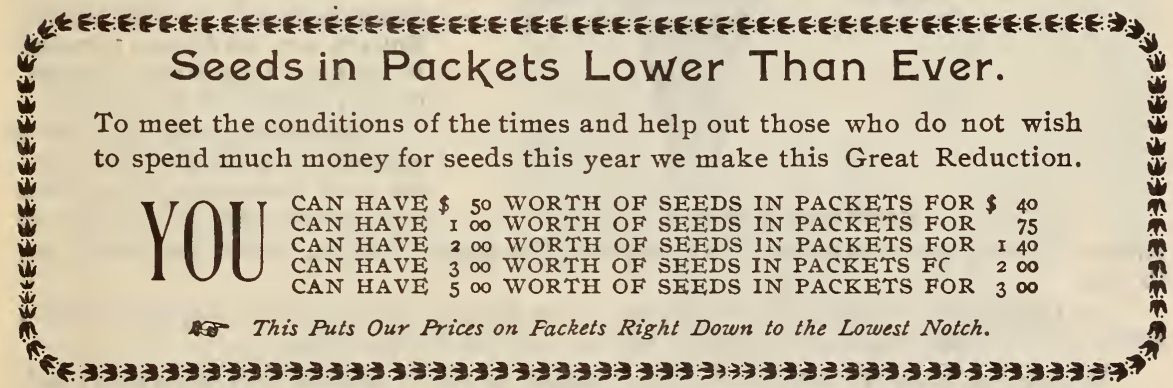

\section{SWEET PEASrrThe New Dwarf Sweet Pea,}

Cupid-Grows only five inches high. Fancy a solid area of deep green-just as green as Cypress-a carpet of plants only five inches high, spreading out from the roots, so as to meet when the seed is planted two feet apart in rows; then fancy this carpet of deep, living green springing into blossom in one week, all a mass of white. clear, waxy white, Sweet Peas on stems only four inches long, and a hundred on a plant, all white like a mass of snow. Pkt. 5c, oz 20c. 


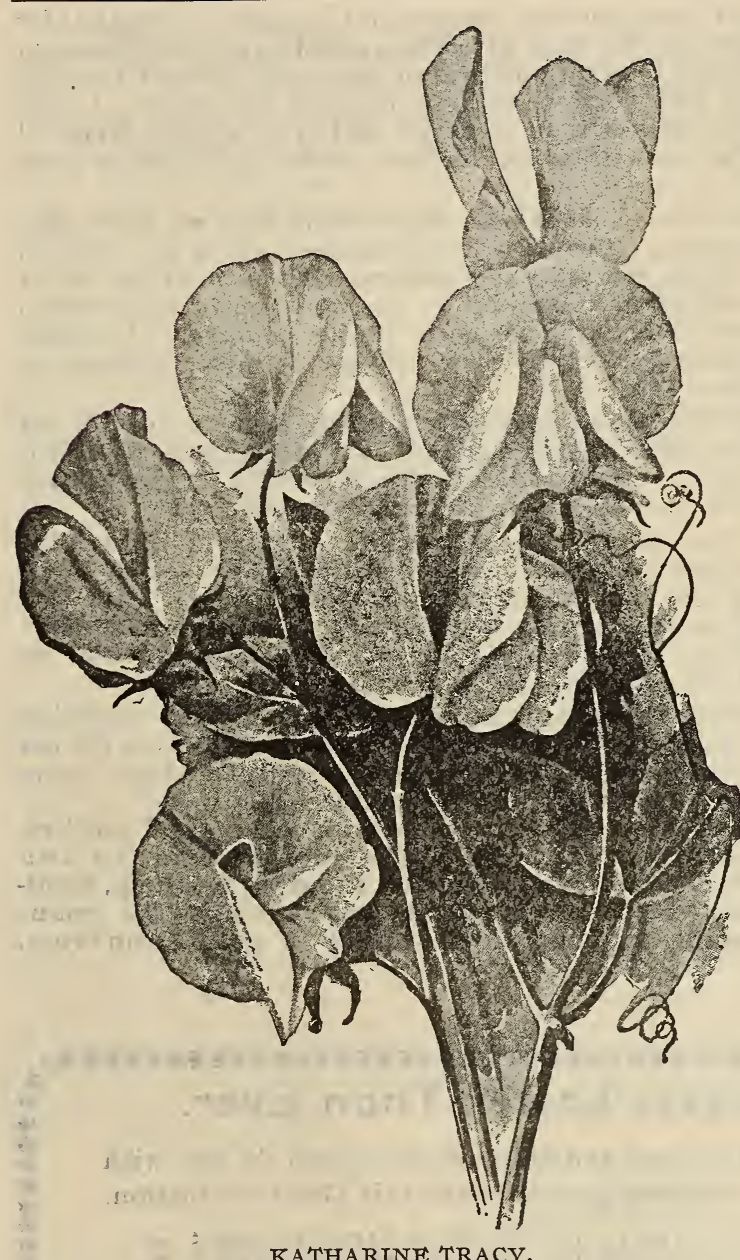

Katharine Tracy-The largest and finest pink sweet pea. This is perfectly formed and unsurpassed in size. Color is soft, brilliant pink throughout. Vines are hardy, and the bloom abundant the whole season. One of the best in size, form and color. Pkt $5 \mathrm{c}$, oz Ioc, quarter $1 \mathrm{~b} 20 \mathrm{c}, 1 \mathrm{~b} 6 \mathrm{oc}$.

Apple Blossom-Standard rose pink, lighter at the base; wings lighter than the standard. Pkt 5c, oz IOc, quarter $1 \mathrm{~b} 20 \mathrm{c}, 1 \mathrm{~b} 6 \mathrm{oc}$.

Blancheferry-Standard medium sized, but of fine form and bright pink; wings large, rounded and nearly white. This variety is recognized as the best of the older and cheaper sorts, either for forcing or the garden. Pkt 5c, oz IOc, quarter $1 \mathrm{~b} 20 \mathrm{c}, 1 \mathrm{~b} 6 \mathrm{oc}$.

Captain of the BluesThe bluest of sweet peas. Standard large, broad, bright, purple blue; wings expanded, lighter and brighter blue than standard. $\mathrm{Pkt} 5 \mathrm{c}, \mathrm{Oz}$ IOc, quarter $1 \mathrm{~b} 20 \mathrm{c}, 1 \mathrm{~b} 6 \mathrm{oc}$.

Blanche Burpee-New. A spendid pure white variety. While not so profuse a bloomer or as hardy a plant as some other varieties, the individual flowers are so fine as to make it a desirable sort. Pkt $5 \mathrm{c}$, oz Ioc, quarter $1 \mathrm{~b} 20 \mathrm{c}, 1 \mathrm{~b} 6 \mathrm{oc}$.

Butterfly-Sta n d a rd a combination of shades of violet and lavender; it is often notched on the sides. Wings

similar in color to the standard, but deeper at the edge. $\mathrm{Pkt} 5 \mathrm{c}, \mathrm{oz}$ IOc, quarter $1 \mathrm{~b} 20 \mathrm{O}$, 1b 5 oc.

Indigo King-Standard, round, flat, very rich purple maroon; wings very broad and bluer than the standard. Pkt $5 \mathrm{c}$, oz Ioc, quarter $1 \mathrm{~b} 20 \mathrm{c}, 1 \mathrm{~b} 6 \mathrm{o}$.

Blushing Beauty-An exceedingly large, perfectly formed and beautifully colored flower. Standard large, very thick and both it and the wings are a peculiar beautiful, delicate, soft, pink. Pkt. 5c, oz 1oc, quarter $1 \mathrm{~b} 20 \mathrm{c}, 1 \mathrm{~b} 60$.

Choice Mixed-This mixture only of the choicest sorts, new and old, in just the right proportion of white, bright red, pink, mauve and other colors to make the most brilliant show possible in the garden. It is unsurpassed by any mixture offered, and could not be better if we listed it at three times the price. Pkt $5 \mathrm{c}, \mathrm{oz}$ ro, quarter $1 \mathrm{~b}$ I5c, $1 \mathrm{~b} 6 \mathrm{oc}$.

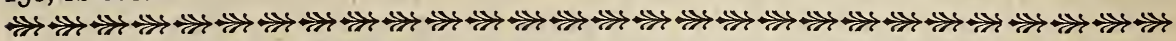

Specipl Offer-One packet each of the foregoing ten grandest of all Sweet Peas for only $25 c$, 


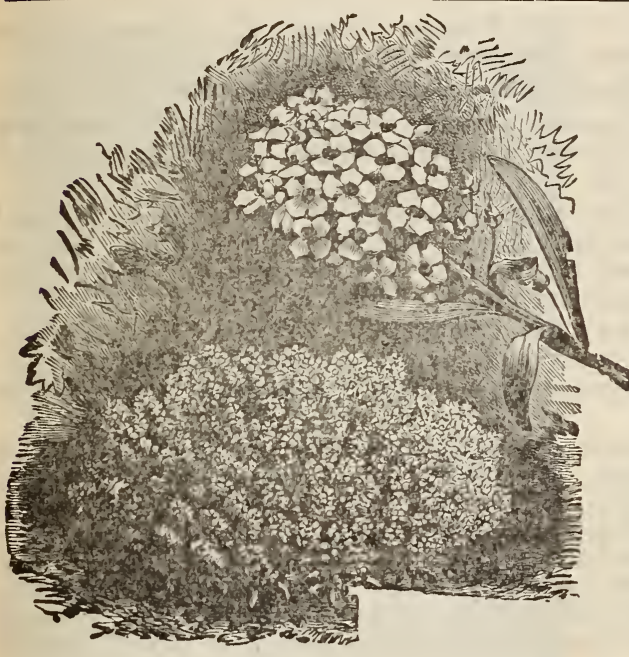

ALYSSUM.

flowers. Plants grow about 20 inches high, each one carrying from ten to twenty flowers. Our strain of seed is of unexcelled quality. White, pkt 5c; Rose, pkt 5c; Lighat Blue. pkt 5c; Crimson, pkt 5c; finest mixed and all the above and others, pkt $5 \mathrm{c}$.

Balsam-(Lady's Slippers) Old and well-known favorites with everyone, owing to their gorgeous masses of beautiful, brilliant-colored flowers. Pkt $5 \mathrm{c}$.

Mixed-A11 colors and varieties.

Cypress Vine-A mong ou r most beautiful climbing plants, dark green, very graceful, fern-like foliage, thickly studded with brilliant, flowers. Pkt $5 \mathrm{c}$.

Cypress Mixed-All colors, including new and attractive varieties. Pkt 5c.

Coxcomb-Highly ornamental plants, producing crested heads of flowers, somewhat resembling a cock's comb. There are many shapes and colors. Mixed, all colors. Pkt $5 \mathrm{c}$.

Bachelor's Button-This is the widely known and ever popular

\section{Choice Flower Seeds}

Ageratum-Valuabfe plants for large beds or borders. Choicest colors mixed. Pkt $5 \mathrm{c}$.

Am ranthus-Choicest colors mixed. Pkt $5 \mathrm{c}$.

Sweet Alyssum-An old favorite; as easily grown as a weed. Thrives in flower gardens, window boxes, vases, etc. Flowers white, very fragrant, valuable for cutting, 9 in. Pkt. 5c.

Antirrhinum (Snapdragon) -Beautiful spikes of gaily-colored flowers produced abundantly the first summer until after frost. Choicest blotched varieties; best mixed. Pkt $5 \mathrm{c}$.

\section{ASTERS,}

Improved Victoria Astershaving large, double globe-shaped

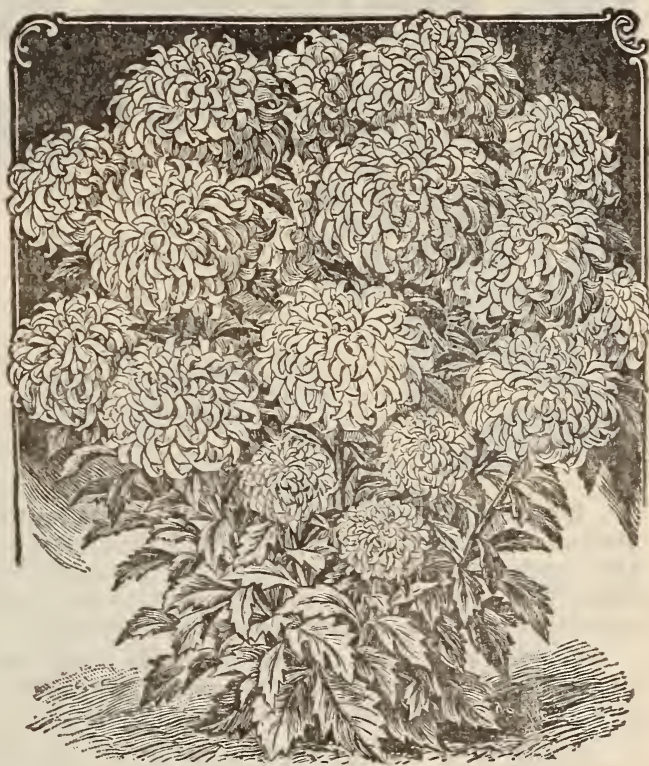

ASTERS.

"Corn Flower," or "Corn Bottle," which, if the seed is sown as soon as the ground is fit in spring, will furnish a profusion of white, blue and pink flowers from July until late in autumn Hardy annual; two to three feet high. Mixed.pkt $5 \mathrm{c}$.

Canterbury Bell-Handsome, hardy biennial, rich color and profuse bloom. Their large, bell-shaped flowers are freely produced throughout the summer, and are strikingly handsome. Plant about two feet high. Mixed colors. Pkt 5c.

$\square$ Candytuft-Universally known and cultivated, and considered indispens zble for cutting. All the varieties look best in beds or masses. Hardy annual; one fuot high; mixed colors. Pkt $5 \mathrm{c}$. 
Calliopsis or Coreopsis-Large, bright flowers; blooms all summer; fine for cutting; also called Bright Eyes. Mixed, all colors. Pkt $5 \mathrm{c}$.

Chrysanthemums Annual-Much grown for cut flowers. The plants grow twelve to eighteen inches high, and produce on long stems beautiful large flowers of many bright colors. They flower all summer and make elegant pot plants for winter flowering. Mixed, embracing all colors. Pkt $5 \mathrm{c}$.

Cobae Scandens--A fine, rapid-growing climber, with handsome foliage and large bell-shaped flowers, green at first, but rapidly changing to a beautiful, deep violet blue. A well established plant will run fifty feet in in a season, covering a large veranda with handsome foliage and tender perennial. Pkt Ioc.

Cosmos-Seed sown in April or May and transplanted to open ground will produce plants five to six feet high by September, and from then to November will be covered with hundreds of blossoms three inches across, resembling single dahlias All colors, mixed. Pkt $5 \mathrm{c}$.

Marguerite Carnation-This new class of Marguerite Carnations will bloom about four months after sowing the seed. The flowers are of brilliant colors, ranging through many shades of red, pink, white, variegated, etc., exquisitely sweet and fully 80 per cent perfectly double. The plants succeed alike in the open garden or in pots. Seed sown early in the year will give an abundance of flowers in July. Sown in May and kept pinched back, you will have fine flowers late in the fall until checked by hard frosts. Sown in the autumn, the flowers will be in bloom early in the spring. Thus, by planting at different seasons, flowers can be had all the year round. Pkt $5 \mathrm{c}$.

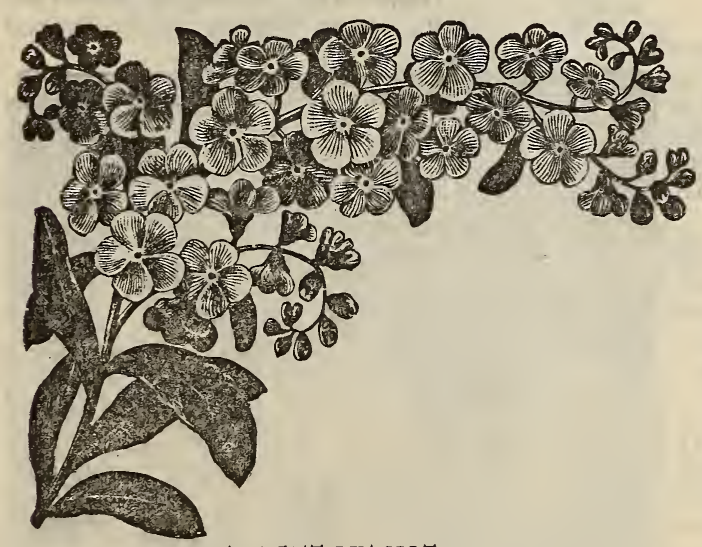

Eschscholtzia (Californai Poppy) - Very attractive plants for beds, edgings or masses. Very profuse in flowering and foliage fine. Bloom from June until frost. Hardy annual, one foot high. Mixed, all colors, choice and bright. Pkt $5 \mathrm{c}$.

Forget-Me-Not(Myosotis) -An old favorite. It flourishes best in a moist, shady situation and is in a constant bloom nearly the whole season. Fall sown seed will flower in early spring. If sown in boxes in the house early, will flower the first season. Six to twelve inches. Pkt $5 \mathrm{c}$.

Four O'Clock-The plants are large and require four feet of space. The flowers are funnel-shaped, white, red and striped, very fragrant, and open about 4 o'clock in the afternoon, remaining open all night, and generally perish about noon the next day. Will grow in any common garden soil, from seed sown in open ground. Hardy annual, two feet high; mixed colors. Pkt $5 \mathrm{c}$.

Gourds-A tribe of climbers with couriously shaped fruit in various colors. Being of rapid growth, they are fine to cover all fences, trellises, stumps, etc. The foliage is quite ornamental. Tender annual; ten to twenty feet high. Pkt $5 \mathrm{c}$.

Larkspur-The Larkspur is one of the handsomest and most useful of plants, and for the large gardens is invaluable. Mixed, hardy annual. Pkt $5 \mathrm{c}$.

Marigolds-These popular, bright, showy flowers only need the slightest care to do well and blossom fieely. Pkt $5 \mathrm{c}$.

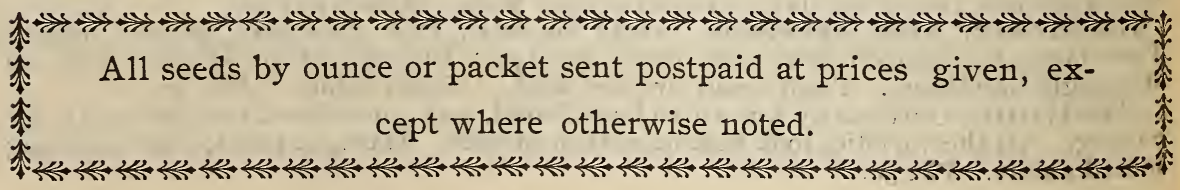




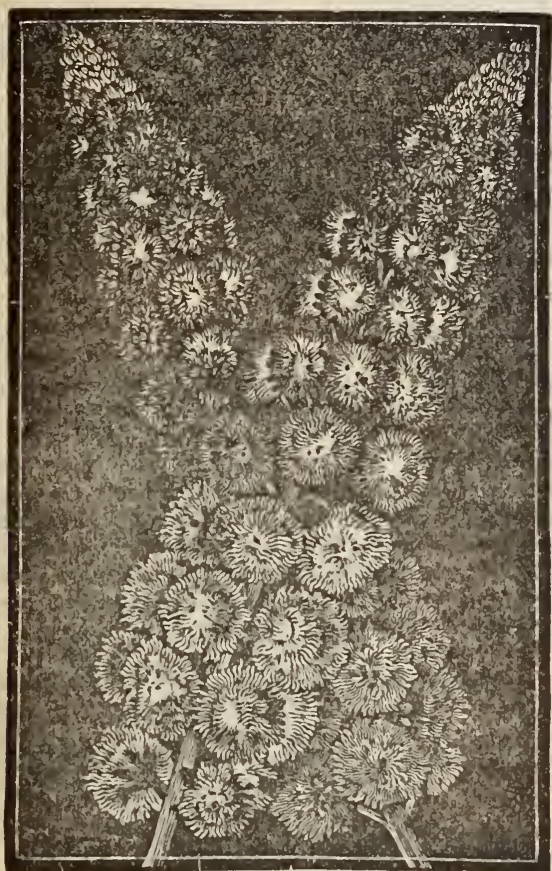

MIGNONETTF

Mignonette-A well-known hardy annual, producing dense, semi.globular spikes of exceedinlg fragrant flowers. It is so fragrant that the whole atmosphere around is perfumed. If sown at intervals in the spring and early summer, it will be in bloom till killed by frosts. Seed sown in autumn will bloom early in spring. Hardy annual; one foot high; choice mixed. Pkt $5 \mathrm{c}$,

Nasturtium (Tall)-This wellknown annual is one of the best fortrellis and arbor decorations; flowers of a great variety of rich colors, stripped and spotted with different shades. Is excellent for vases and baskets, also does finely grown in beds without trellis support; produces an abundance of flowers from first of July until frost. Tall mixed. Pkt $5 \mathrm{c}$.

Nasturtium (Dwarf)-A bed of dwarf Nasturtiums forms an attractive feature in the flower garden. It is hardy annual, grows about one foot high, and will blossom all the season. If the soil is not to rich the flowers will be more brilliant. Dwarf mixed. Pkt 5c.

Hollyhock-An old popular favorite; flowers form perfect rosettes of the most lovely shades of yellow, crimson, rose-pink, white, etc; extra double, mixed. Pkt $5 \mathrm{c}$.

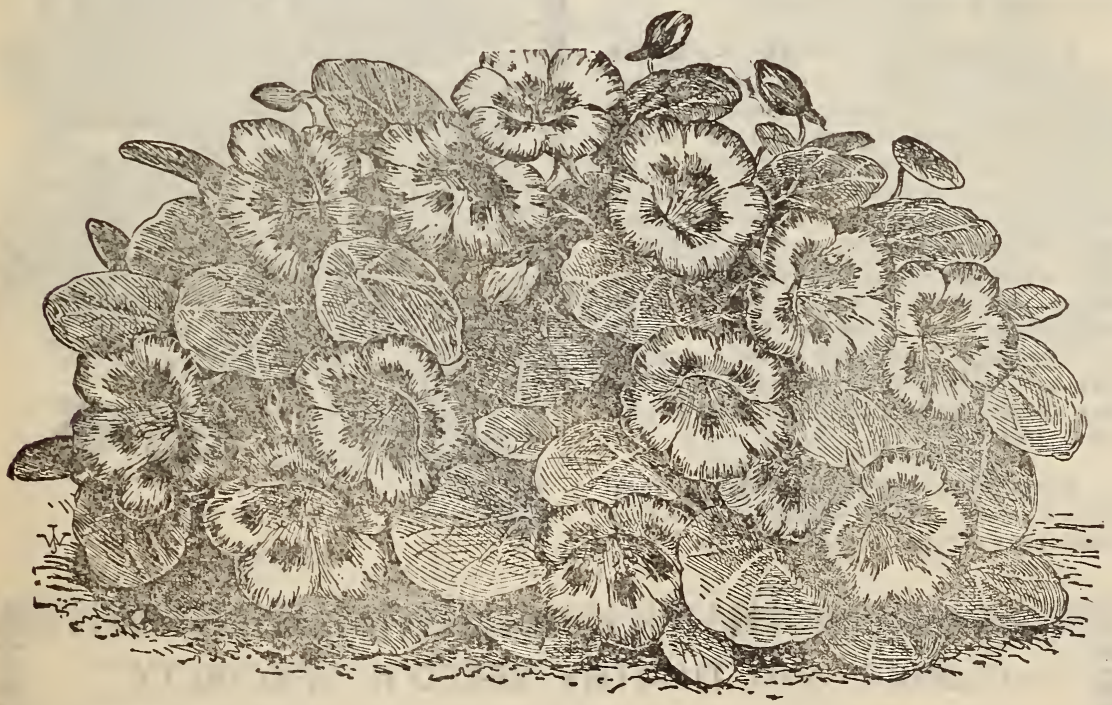


Mourning Bride-The plants produce a profusion of large, double flowers of striking shades of color, which are very useful in making bouquets. Hardy annual; about one foot high; choice mixed. Pkt. 5c.

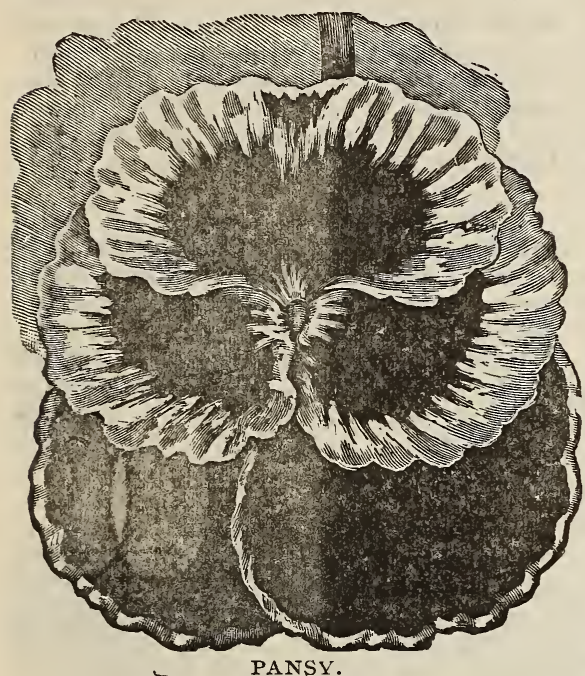

Morning Glory-This well-known annual is one of the most popular climbers. Of rapid growth, soon covering a fence or trellis with abundant foliage and bright flowers. A great variety of colors and shades; hardy annual; mixed colors. Pkt $5 \mathrm{c}$.

Pansy-These lovely flowers are favorites with all, not only for the brilliancy and variety of their colors, but for the durability of their bloom. Pkt $5 \mathrm{c}$.

Prize Pansy Mixture-The best pansies for bedding. Almost an endless variety of all shades and colors, including such famous sorts as Cardinal Red, Peacock Blue, $1 \mathrm{i}$ hı and dark marbled and flive spotted. They are all of sturdy and even growth. I'kt $5 \mathrm{c}$.

Petunia-The Petunia is the people's flower. Succeeds well everywhere. They are showy in beds or masses. Are universal favorites on account of their richness of color, fragrance and continuous blooming. I offer only the choicest sorts in one grand mixture. $\mathrm{p}_{\mathrm{m} i \mathrm{i}} \mathrm{Pkt} 5 \mathrm{c}$.

Poppies-Large, showy, brilliant colored flowers, growing freely in any garden soil. Produce a fine effect in clumps or beds. Finest mixed; all colors and varieties. Pkt $5 \mathrm{c}$.

Dianthus, or Pink - Garden Pinks, like their relatives, the Carnations, are flowers for everybody. They thrive in any soil, grow ten to fifteen inches high and are covered from early summer until overtaken by frost, with beautiful, sweet-scented flowers in various colors; variegated. striped, red, and some almost black. Splendid for boquets. All bloom the first season, and some endure our winters, bloom again another year larger and more beautiful than before. With these good quatities they should have a place in every garden. Pkt 5 c.

Imperial - Blood red, ground striped with pink white. Different from other striped sorts. Pkt $5 \mathrm{c}$.

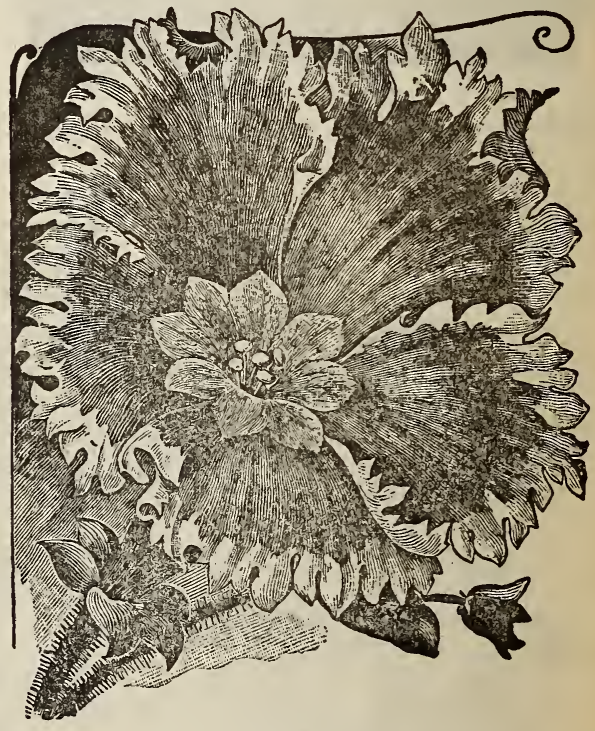

PETUNIA. 


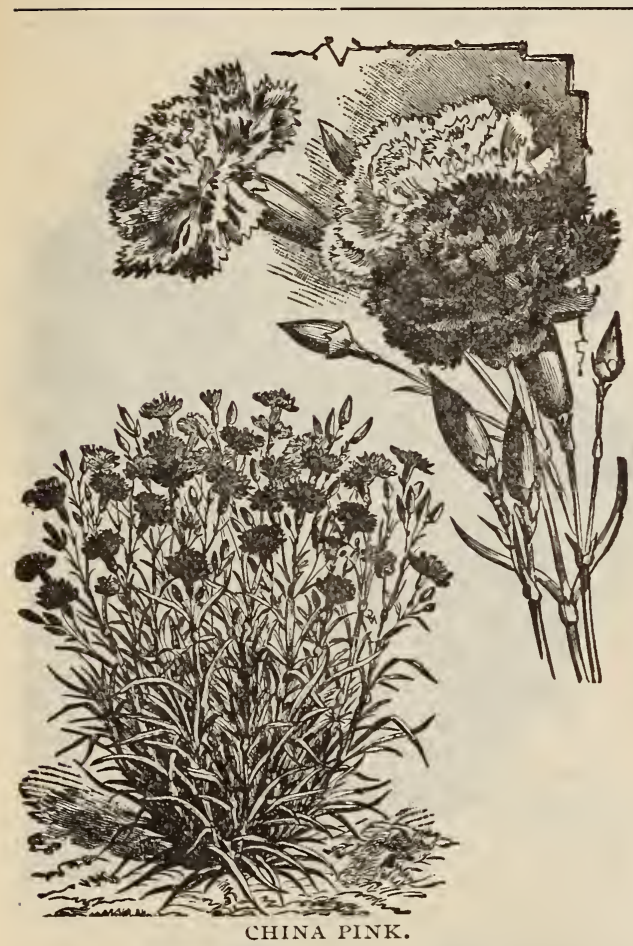

Double Flowering PinkChina or India. Large flowers as double and fragrant as a carnation. Many colors mixed. Pkt $5 \mathrm{c}$.

Phlox (Drummondi) - Very hardy annuals, thriving in almost any situation, and unequalled in the magnificent display of their many and brilliant colored flowers. Seed sown in open ground in fall or early spring will begin flowering about the first of July a d r 2 main literally covered with bloom until after severe frosts late in autumn. For masses of separate colors or for cutting for boquets they are unsurpassed. One foot high. Fine mixed. Pkt $5 \mathrm{c}$.

Verbena-No plant is more generally cultivated, or more deservedly so than the Verbena, as no plant excels it for masses in beds on the lawn. In the varieties may be found every color except yellow. If sown in open ground in May they will bloom in August, but if started in the house in pots, in winter, they will be in bloom sooner. Half hardy perennial trailer; one foot high; choice mixed. Pkt $5 \mathrm{c}$.

Riclnus, or Castor Oil Bean-Planter on the lawn it makes a perfect pyramid of foliage, with gigautic leaves. Ornamental until killed by frost; mixed Pkt $5 \mathrm{c}$.

Stock, Ten WVeeks-Desirable as pot plants, as well as in the open garden. I offer choicest colors in one grand mixture of crimson, yellow, rose, blue, white, brown, golden, etc. Pkt $5 \mathrm{c}$.

Portulara-T h e $r$ e a re scarcely any flowers in cultivation that make such a dazzling display of colors as a bed of Portulacas. They are in bloom from about the first of July until killed by frost in autumn. Tender annual; about six to eight inches high. Single, fine mixed, pkt $5 \mathrm{c}$; double, mixed IOc.

Sweet William-As now improved they make matchless bor-

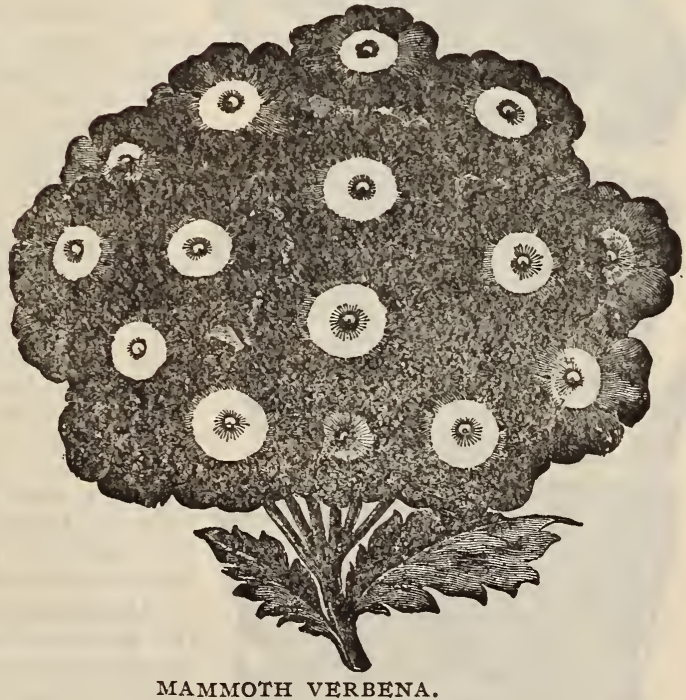
der plants. A splendid strain of all bright colors, of single and double varieties. Pkt 5c.

Wild Cucumber Vine-The most rapid growing vine we know of. Splendid for covering old trees, fences, etc. Will grow thirty feet in one season. Dense, graceful foliage, thickly dotted with white, fragrant flowers. Pkt $5 \mathrm{c}$. 
Zinnia-A very showy plant, with large, double flowers, which, when fully expanded, form hemispherical heads, become densely imbricated and might easily be mistaken for dwarf dahlias. Half hardy annual; about eighteen inches high. Choice mixed, all colors, pkt 5 c.

\section{Summer Flowering Bulbs and Plants.}

Caladium Esculentum-Known as Elephant's Ears. One of the finest Guj tropical plants which can be grown in the open air in the north. It can be made to produce three to ten leaves three to four feet long and nearly as wide, on stalks four to six feet high. It is of easy culture, the chief requisite being an unlimited supply of fertilizer and water. You cannot make the soil too rich or keep it too wet for this plant. Very effective for the flower and for planting out upon the lawn.
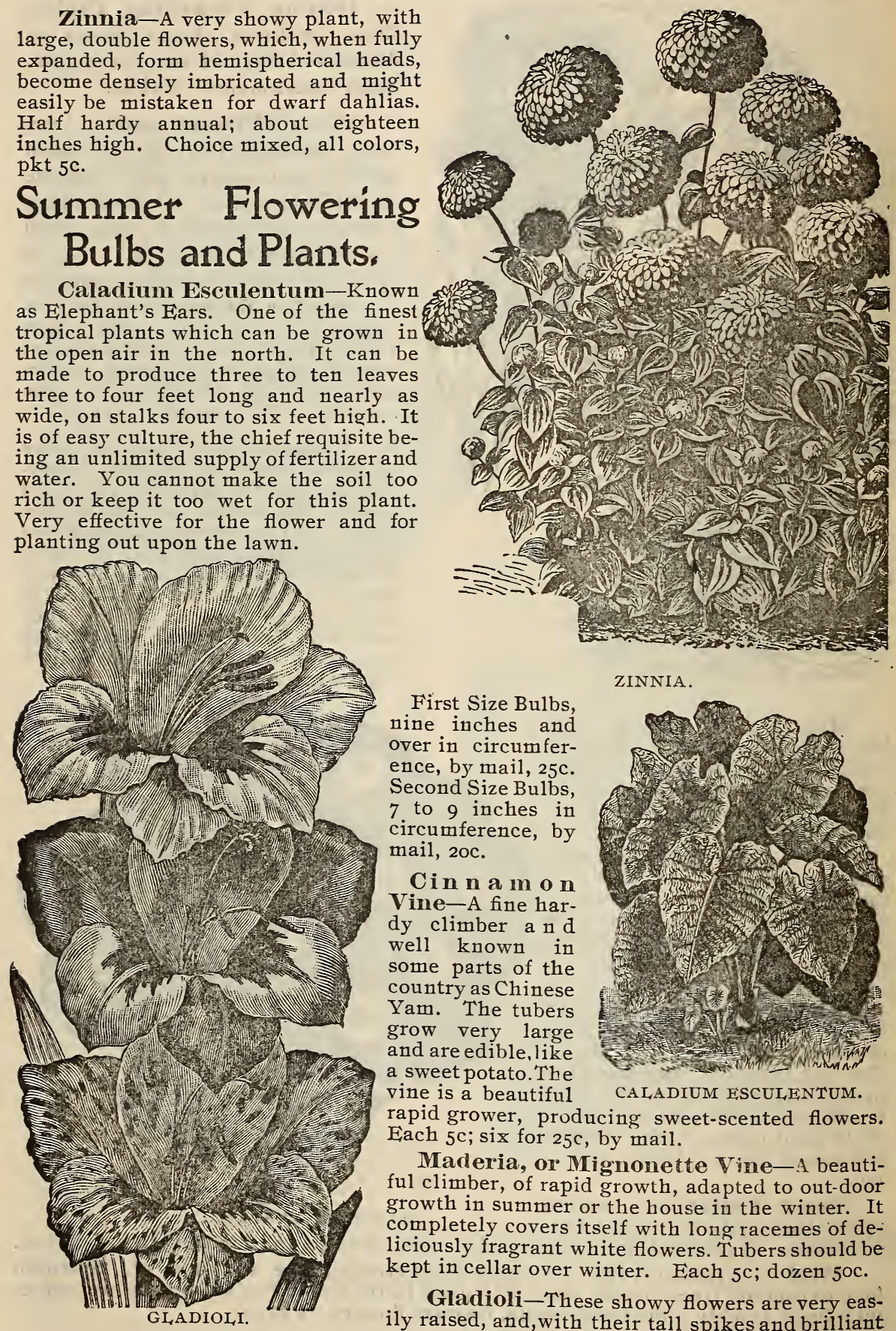

First Size Bulbs, nine inches and over in circumference, by mail, $25 \mathrm{c}$. Second Size Bulbs, 7 to 9 inches in circumference, by mail, 2oc.

Cin $n$ a $m$ o $n$ Vine-A fine hardy climber a n d well known in some parts of the country as Chinese Yam. The tubers grow very large and are edible, like a sweet potato. The vine is a beautiful ZINNIA.

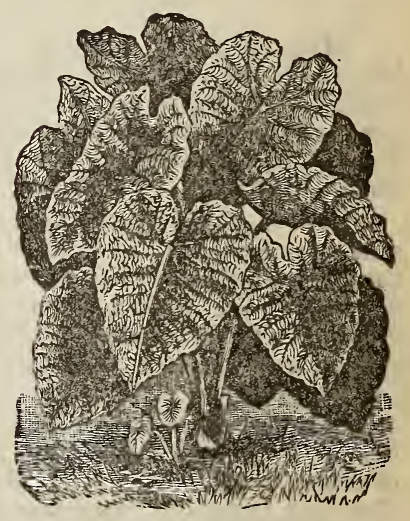

CALADIUM ESCULENTUM. rapid grower, producing sweet-scented flowers. Each $5 \mathrm{c}$; six for $25 \mathrm{c}$, by mail.

Maderia, or Mignonette Vine-A beautiful climber, of rapid growth, adapted to out-door growth in summer or the house in the winter. It completely covers itself with long racemes of deliciously fragrant white flowers. Tubers should be kept in cellar over winter. Each 5c; dozen $50 \mathrm{oc}$.

Gladioli-These showy flowers are very easily raised, and, with their tall spikes and brilliant 


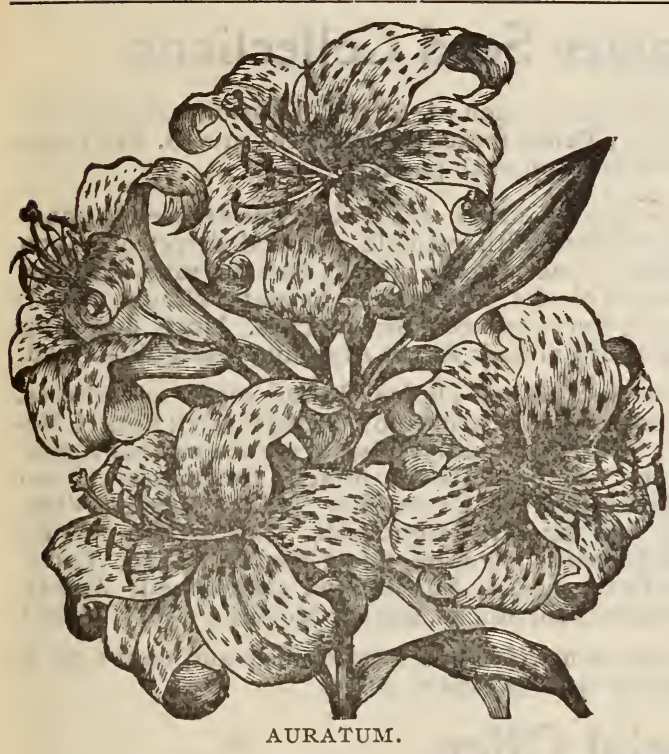

colors of almost every variety, simple and blended, make one of the most magnificent displays of the flower garden. By planting from May until July, a continuous succession of flowers will be secured. Plant in rows one foot apart, six inches apart in the row, and two inches deep. All colors; mixed, by mail, 5c each; 25c doz.

Dahlia-The Dahlia has always been a favorite for autumn flowering. The flowers are so symmetrical and perfect, and the range of colors so large and varied that they will always be popularwhere display is wanted. The roots are tender and easily injured by frost. They should be set out three feet apart, after all danger of frost is over, and during winter placed in a cool cellar, and not allowed to freeze. The plants should be supported by tying to stakes. Double pink, scarlet, white and yellow, each, by mail, $20 c$.

Lilium Auratum-(The Golden Rayed Lily of Japan.) This peerless variety is beyond question the grandest of all the Lily family. The flowers are pure white thickly studded with crimson spots, while through the center of each petal runs a clear golden band. Flowers measure nearly a foot across, produced abundantly; deliciously fragrant, two to five feet. First size bulbs, I5c, three for 40c, postpaid; not prepaid, large bulbs Ioc each; dozen $\$$ I.00.

Album-This Lily is a pure white and very fragrant variety, with beautiful recurved petals. A very fine sort. Each, I5c; dozen, \$1.50, prepaid; not prepaid, Ioc each, dozen $\$$ r.oo,

Rubrum-White ground with band and spots of rose or crimson on each petal. One of the best Lillies. We have a splendid stock of this very hardy and beautiful kind. Each, I5c; dozen, $\$ 1.50$, postpaid; not prepaid, each Ioc; dozen, $\$ 1.00$.

Cannas-Few of any flowers that are produced from tubers will give such a strikingly beautiful effect as these trusses of Cannas when in bloom. Early in June they come into flower and continue until late in September. Cannas are the most popular decorative plants of the day. Strong, dry roots, I5 each; Io for \$I.vo, postpaid.

TUBE ROSES, Pure white, waxy flowers. Extremely fragrant. Only

Tall Double-Three to five feet high, strong and free blooming. Prepaid, 6 for 20c; per dozen, $35 \mathrm{c}$.

Pearl-Larger, better and more flowers produced by this sort than the old variety, Stems short, from two to three feet high. Prepaid, 6 for $20 \mathrm{c}$; dozen $35 \mathrm{c}$.

Moonflower-The true Moonflower is the most vigorous of all summer climbers; a single plant can easily be made to cover, by August I5, a trellis thirty to fifty feet high and six feet broad, with a dense mass of leaves, studded every night or cloudy day with hundreds of beautifully white and wax-like flowers, four to six inches in diameter, Height 30 to 50 feet; tender annual. Pkt $5 \mathrm{c}$.

Coleus-Probably there is no other kind of foliage plant so well known and universally admired as the Coleus. It is one of the most beautiful of our variegated perennial foliage plants for the green house or garden decoration, ribbon beds, etc; of rapid growth and easy culture. Tender perennial; height I to 2 feet. Pkt $5 \mathrm{c}$. 


\section{Our Bargain Flower Seed Collections,}

Our 12-

Cent Bargain Postpaid.

Our 25-Cent Bargain. Postpaid.

\section{Our}

50-Cent Bargain. Postpaid.

\section{$\$ 1.00$} Bargain.
Contains one full size packet each of Sweet Alyssum, Mignonette mixed, Morning Glory, Pansy mixed, Sweet Peas mixed, five packets with culture directions on each packet.

Contains twelve full-sized packets of choice flower seeds, handsomely illustrated in colors, with reliable cultural directions upon each packet, as follows: Aster, choice mixed; Balsam, mixed; Pinks, Chinese mixed; Four O'clocks, fine mixed; Petunia, choice mixed; Phlox, mixed; Poppy, finest mixed; Sweet Peas, large flowering mixed; Verbena, splendid mixed; Sweet Alyssum, Marigold, mixed.

Contains twenty-five packets of choice flower seeds as follows: Pansy, large flowering mixed; Carnations, Pinks mixed; Forget-MeNot; Phlox, mixed; Sweet Alyssum; Verbena, choice mixed; Ageratum, fine mixed; Aster, mixed: Balsam, mixed; Calliopsis, mixed colors; Cosmos, choice mixed; Canterbury Bells; Cypress Vine, mixed; Candytuft, fine mixed; Mignonette; Nasturtium, dwarf mixed; Petunia, choice mixed; Poppy, finest double mixed; Portulaca, mixed; Sweet Peas, mixed; Nasturtium, tall mixed; Zinnia, mixed;Four O'clocks, mixed; Stocks, mixed; Morning Glory, mixed.

Forty packets of your own selection of Sweet Peas and flower seeds from this catalogue by mail, postpaid, $\$ 1.00$.

\section{Special Offer.}

\section{A Complete Vegetable Garden for $\$ 1.00-34$ Packets.}

I pkt Golden Wax Beans.

I pkt Early Eclipse Beet.

I pkt Cabbage, Early Summer.

I pkt Cabbage, Surehead.

I pkt Cauliflower.

I pkt Carrot, Ox Heart.

I pkt Celery, White Plume.

I pkt Corn, Stowell's Evergreen.

I pkt Corn, Early Minnesota.

I pkt Cucumber, Early Cluster.

I pkt Cucumber, White Spine.

I pkt Lettuce, St. Louis Market.

I pkt Lettuce, Black Seeded Simpson.

I pkt Watermelon, Dixie.

I pkt Watermelon, Kolb's Gem.

r pkt Muskmelon, Osage.

I pkt Muskmelon, Early Hackensack.
I pkt Onion, Yellow Globe Danvers.

I pkt Onion, Prizetaker.

I pkt Pepper, Ruby King.

I pkt Parsley, Moss Curler.

I pkt Pumpkin, Sugar.

I pkt Parsnip, Hollow Crown.

I pkt Peas, Champion of England.

I pkt Peas, First and Best.

I pkt Radish, Early Long Scarlet.

I pkt Radish, Early Scarlet Turnip.

I pkt Spinach, Bloomsdale.

I pkt Squash, Summer Crookneck.

I pkt Squash, Hubbard.

I pkt Tomato, Ponderosa.

I pkt Turnip, Purple Top Milan.

I pkt Turnip, Purple Top White Globe.

I pkt Salsify, or Vegetable Oyster.

16 Packets of Choice Vegetable Seed for 50c, Postpaid.

I pkt Beets, Early Blood Turnip.

I pkt Beans, Golden Wax.

I pkt Cabbage, All Seasons.

I pkt Carrot, Danvers.

I pkt Celery, Golden Self-Banching.

I pkt Corn, Stowell's Evergreen.

I pkt Cucumber, White Spine.

I pkt Lettuce, Early Curled Simpson.
I pkt Muskmelon, Osage.

I pkt Watermelon, Sweetheart.

I pkt Onion, Yellow Danvers.

I pkt Radish, French Breakfast.

I pkt Peas, Telephone.

I pkt Tomato, Perfection.

I pkt Squash, Hubbard.

I pkt Turnip, Early Purple Top Milan.

\section{Packets Choice Vegetable Seeds for 25c, Postpaid.}

I pkt Beet, Eclipse.

I pkt Cucumber, Early Cluster.

I pkt Lettuce, Hanson.

I pkt Radish, Chartier.
I pkt Cabbage, Early Jersey Wakefield.

I pkt Muskmelon, Netted Gem.

I pkt Onion, Yellow Danvers.

I pkt Tomato, Livingston Beauty. No discount or changes allowed on vegetable and flower seed bargains. 


\section{"Planet Jr." Tools for 1901.}

Space will not permit our showing and describing all the "Planet Jr." tools, but we will send a fully illustrated catalogue free for the asking to any who desire it. Great improvements have been made for Igor.

This seeder is the latest and most perfect development of the hand seed drill. It sows evenly in drills, and also drops in hills at $4,6,8,12$ or 24 inches apart. It is thrown out of gear instantly by moving a convenient lever, or the flow of seed is stopped by pushing down the feed rod. No time is lost; no seed is wasted. It is quickly set to sow different kinds of seed in the exact thickness desired. It covers and rolis down light or heavy and marks the next row clearly. Hopper holds $2 \frac{1}{2}$ quarts; it runs light and sows

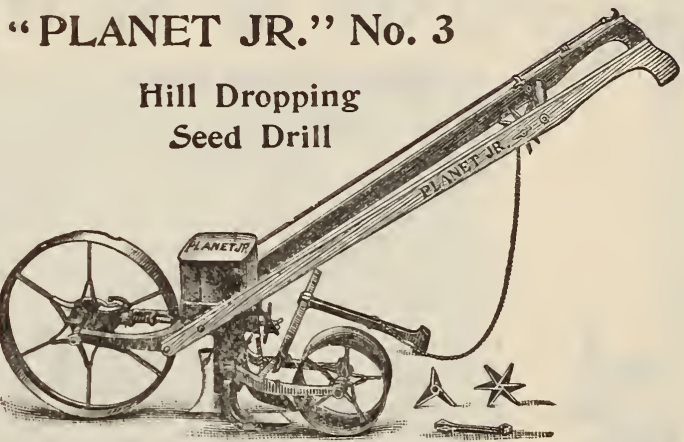
equally well with a full hopper or a tablespoonful of seed. The accurate hill dropping drill, which gives a regular stand of plants with the least seed, saves its cost over and over in seed alone. We guarantee this drill to be more accurate than any other made, and to give satisfaction in every respect. Price, \$10.00.

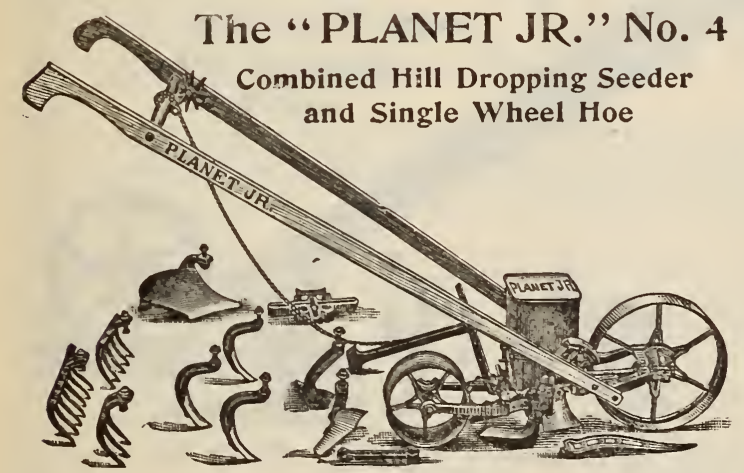

This admirable tool combines in single convenient implement a capital hill dropping seeder, a hoe, a cultivator, a rake and a plow. It holds 3 pints and as a seeder is like No. 3, sowing in continuous rows or dropping in hills at any distance. It is thrown out of gear by simply raising the handles. The index is accurate, simple and easily set. The drill is detached and the tool frame substituted by removing but one bolt. It then becomes a single wheel hoe,garden plow cultivator or rake. It is useful

almost every day of the season 6 at every stage of garden work. With this one implement the small farmer can do practically all the work in his small crops. Price, complets, $\$ 11.00$; as a seeder only, $\$ 8.00$.

This perfeet wheel hoe is invaluable for use in all small crops Its variety of work is almost incredible, Changes and adjustments of tools are made with the grestest quickness. It has II-inch wheels which can be set at four different distances apart; the "PLANET JR." No. 11 Double Wheel Hoe, Cultivator, Rake frame is malleable with ample

and Plow.

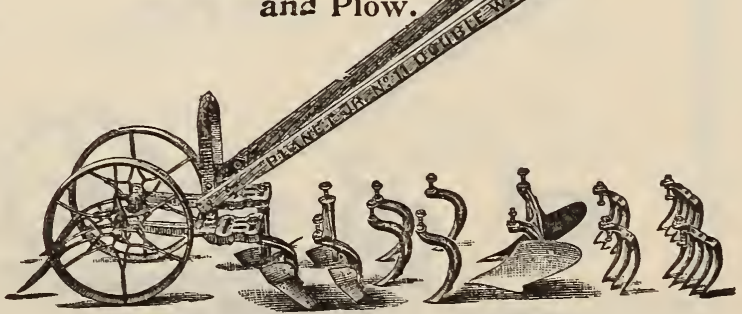


room for tool adjustment and can be set at three different heights. The handles are adjustable at any height, and being attached to the arch, are undisturbed in making changes of adjustment in frame, wheels or toois. The arch is of stiff steel, unusually high; the quick change frame permits the tool to be changed without removing the nuts. Seven pairs of tools as shown in the cut, go with the wheel hoe. All the blades are of tempered and polished steel. Price $\$ 8.50$.

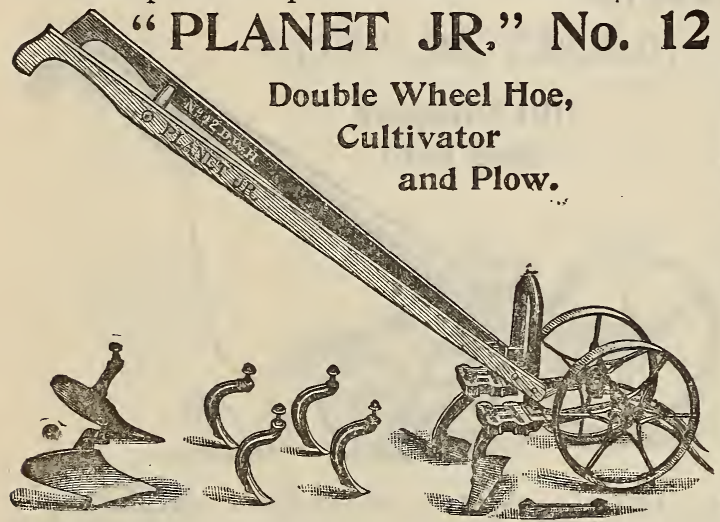

This tool is identical with No. II Wheel Hoe, except that it has fewer attachments and is sold at a correspondingly less price. The tools shown with No. I2 are what gardeners use most, and the others can be added as wanted. $\$ \mathbf{\$ 6 . 5 0}$.

\section{Double Wheel Hoe. No. 13.}

This tool is the No. II, with 6 inch hoes only, these being the tools that are most generally useful. Any or all of the other tools shown with No. I r may be added. at any time and are sure to fit. Price $\$ 4.50$.

This latest and best single wheel hoe, improved for Igor. It has Ir-inch wheel with broad face; it is very light, strong and easy running. It has adjustable handles and quick change frame. The frame changes in height, and the wheel may be attached to the other side of the frame, when both sides of the row may $b$ ? hoed at one passage. $\$ 5.50$.

No. I7 is identical with No. I5, but has only a pair of 6-ince hoes, a plow and a set of cultivator teeth-an outfit sufficient for most

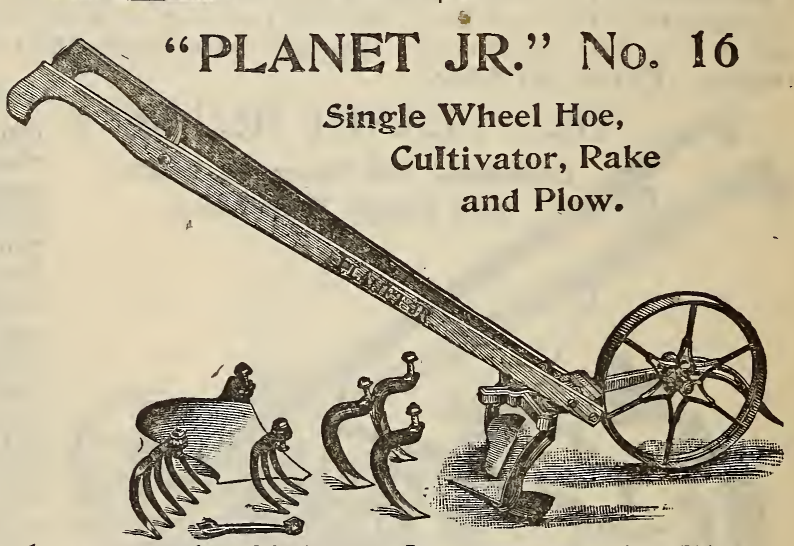
garden work. The other attachments can be added at anytime. Price \$4.75.

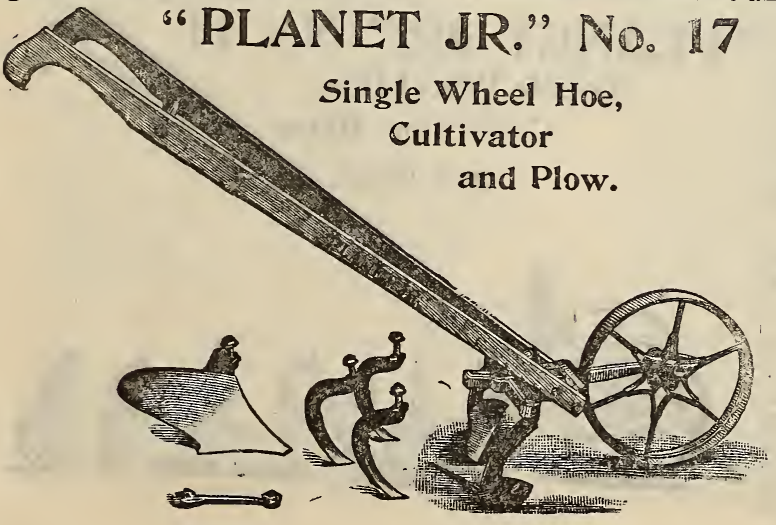

No. 18.

\section{Single Wheel}

\section{Hoe.}

This tool has the same frame and handles as No. I5, but has one pair of 6inch hoes only-the tools that are most constantly useful throughout the season. All the other tools can be added as needed. Price $\$ 3.25$. 


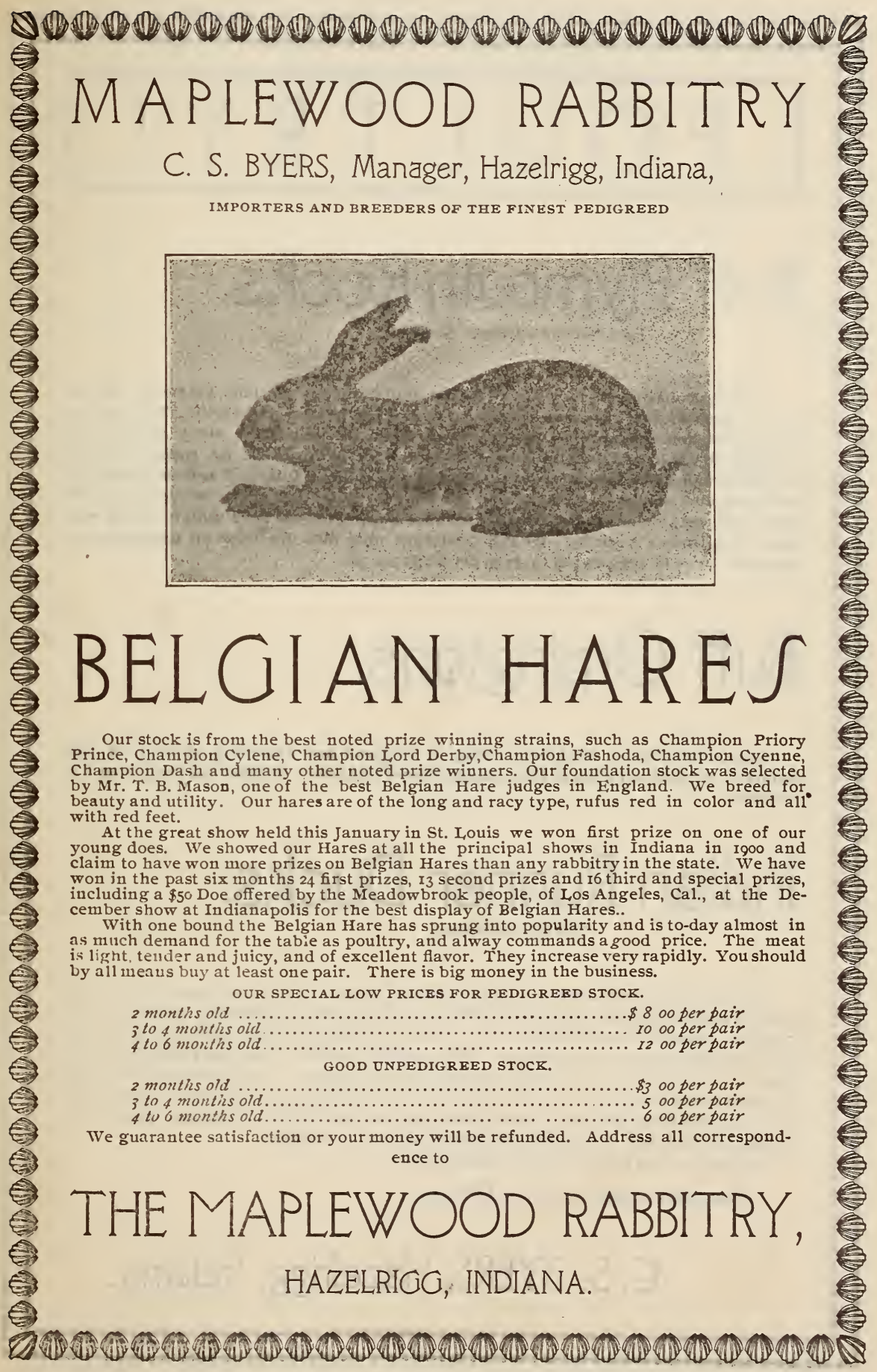




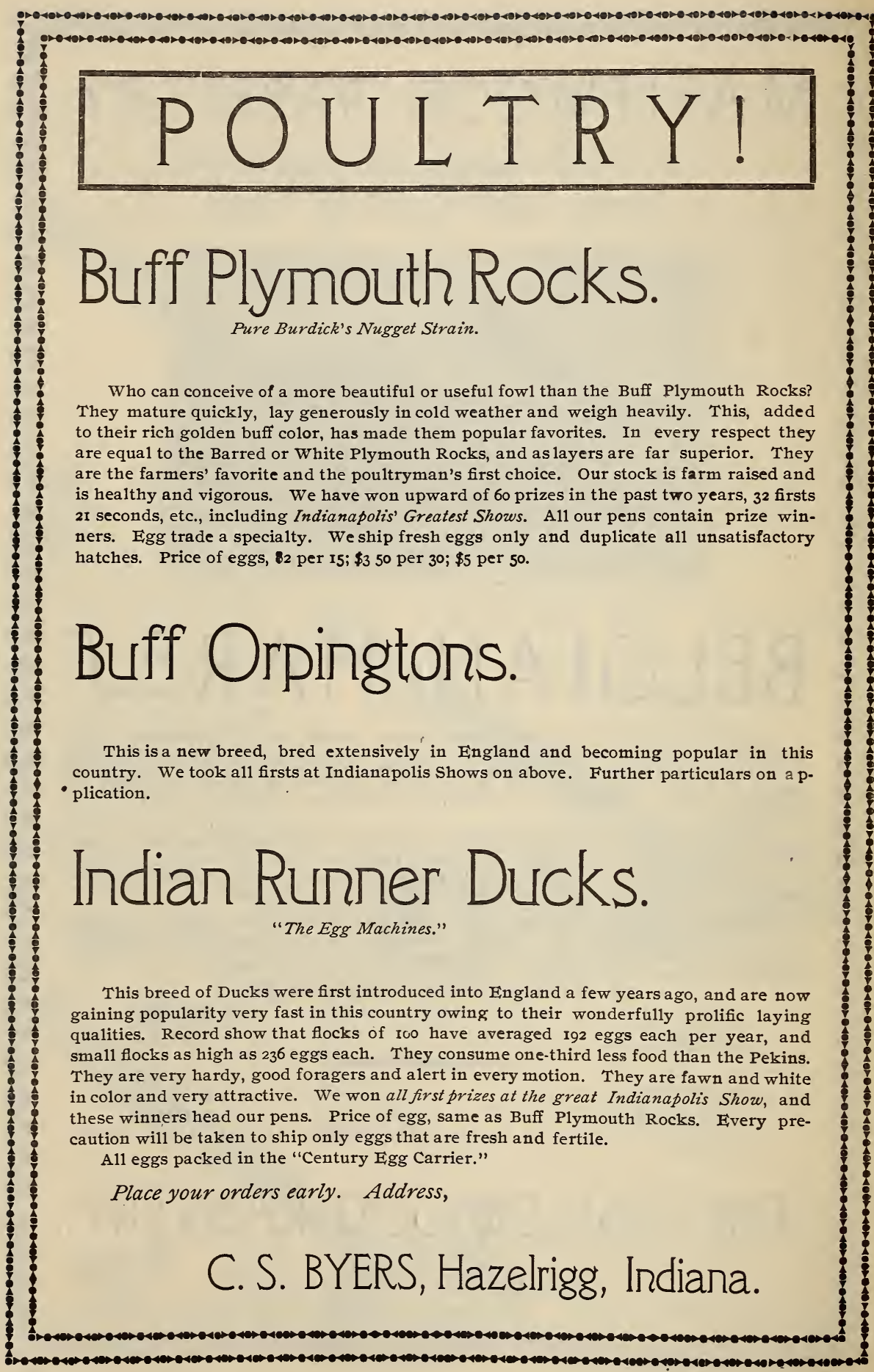




\section{ADOLPHUS MYYSONG, \\ Lebanon. Indiana.}

Name

Postoffice.

County

State

Freight or
Express Office
Cash, : $\$$

P. O. Order, ?

Exp. Order,

Draft, :

Stamps, :

Total, : \$

Dear Sir

Date

Enclosed find \$.

for which send the following :

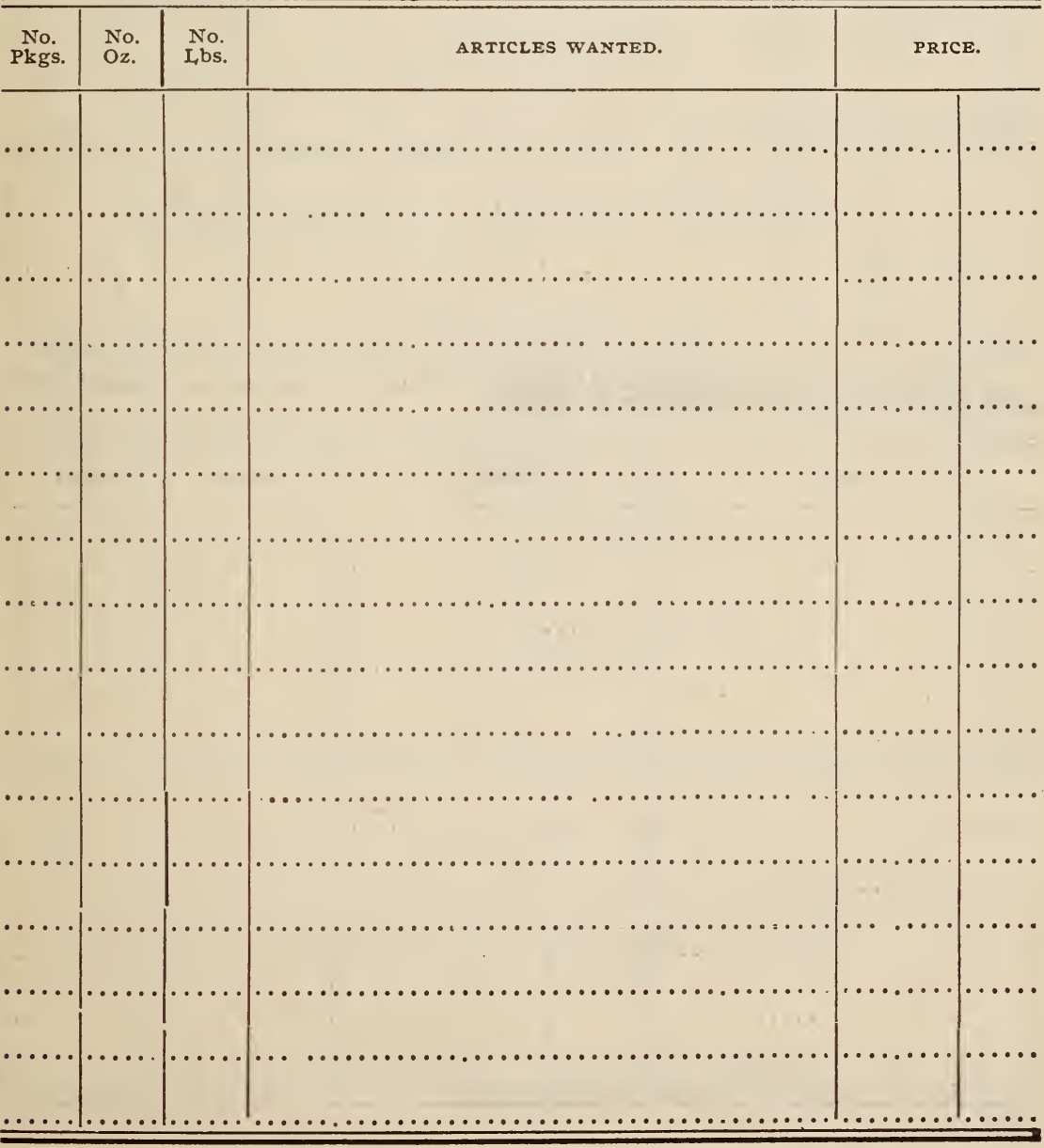




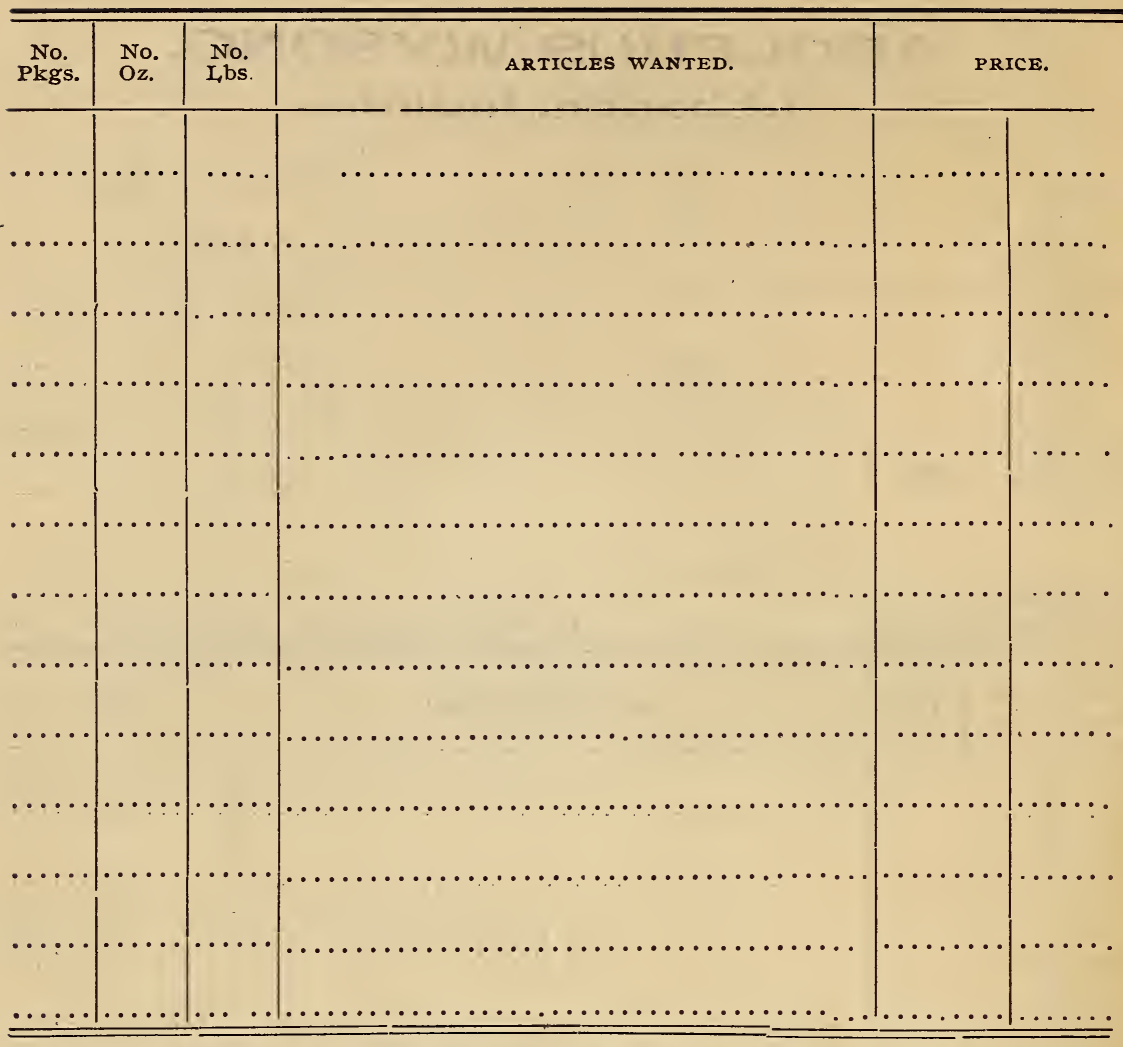

We would esteem it a favor if you would send us the names of a few of your friends that you think would like to receive a copy of our Catalogue.

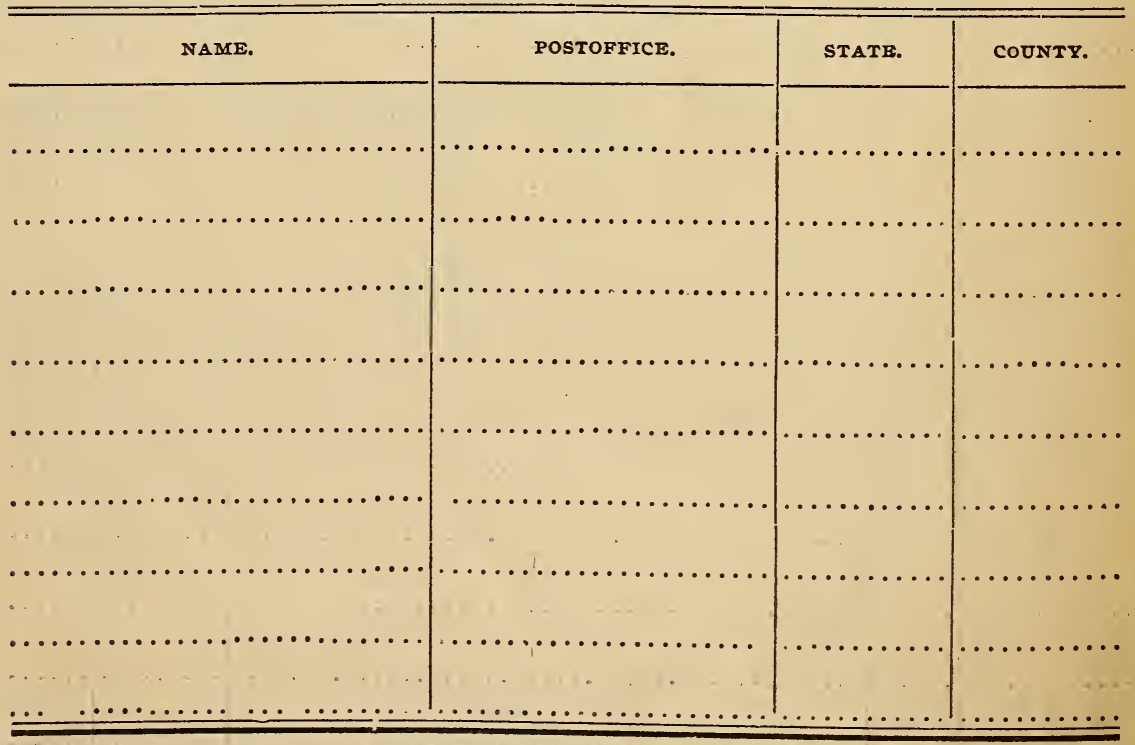




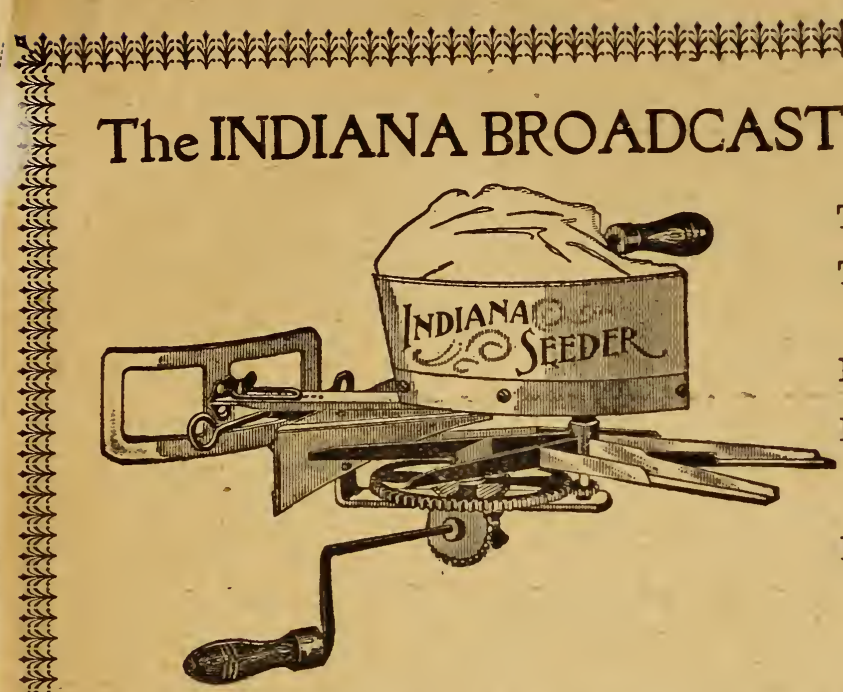

The Best on Earth.

The Handsomest in

Appearance.

Lightest Running.

Most Durable and

Sells at Sight.

Nothing ever Man-

ufactured to

OompareWith It.

Cast Iron Bevel Wheels, Sheet Steel Hopper, Heavy Tin Fan, Steel Balance. Holds one-half bushel of seed. I'rice \$1.50.

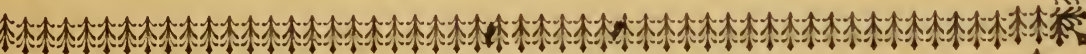
㛢

\section{Bushel Measure of Seeds and Merchandise.}

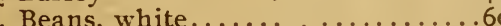

筷 Buckwheat................... 50

\# Broom Corn................... 46

Millet, common ....................

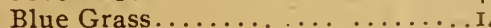

Millet, German ............. 50

Oats ..............................

Orchard grass $\cdots \ldots \ldots \ldots \ldots \ldots . \ldots \ldots+\ldots \ldots$

..... 14

* Corn, shelled ... ...........56 Potatoes, Irish . ............60

* Corn, ear...............6.68 Potatoes, sweet . .......... 55

Cane, amber....................50 Peas, Canada field $\ldots . . . \ldots \ldots \ldots$

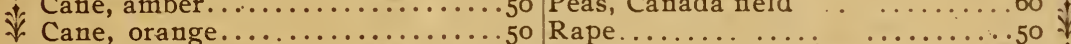

* Clover seed................6. 6o Rye ...................... 56 *

Cranberires................................

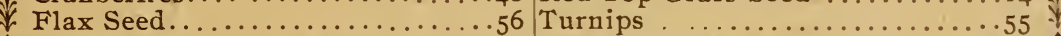

$\$$ Hungariati.......................... Th

Hemp.....................44

(

\section{WE SELL PRATT'S POLLTRY AND STOCK FOOD.}

Pratr's Poultry Food will keep hens in good health and cure chicken cholera and other diseases of chickens and turkeys. It is a splendid egg food, endorsed by leading poultry raisers. It makes larger fowls, quickens the growth of young chicks, and sickly broods are never seen where it is used. Per 5-1b pkg 6oc; 26 oz pkg 25c. STOCK FoOD for horses, cattle, hogs and sheep will keep them in the best of condition.

Pratt's Animal Regulator 25c. Pkg 50c; 12-1b pkg 75c. 


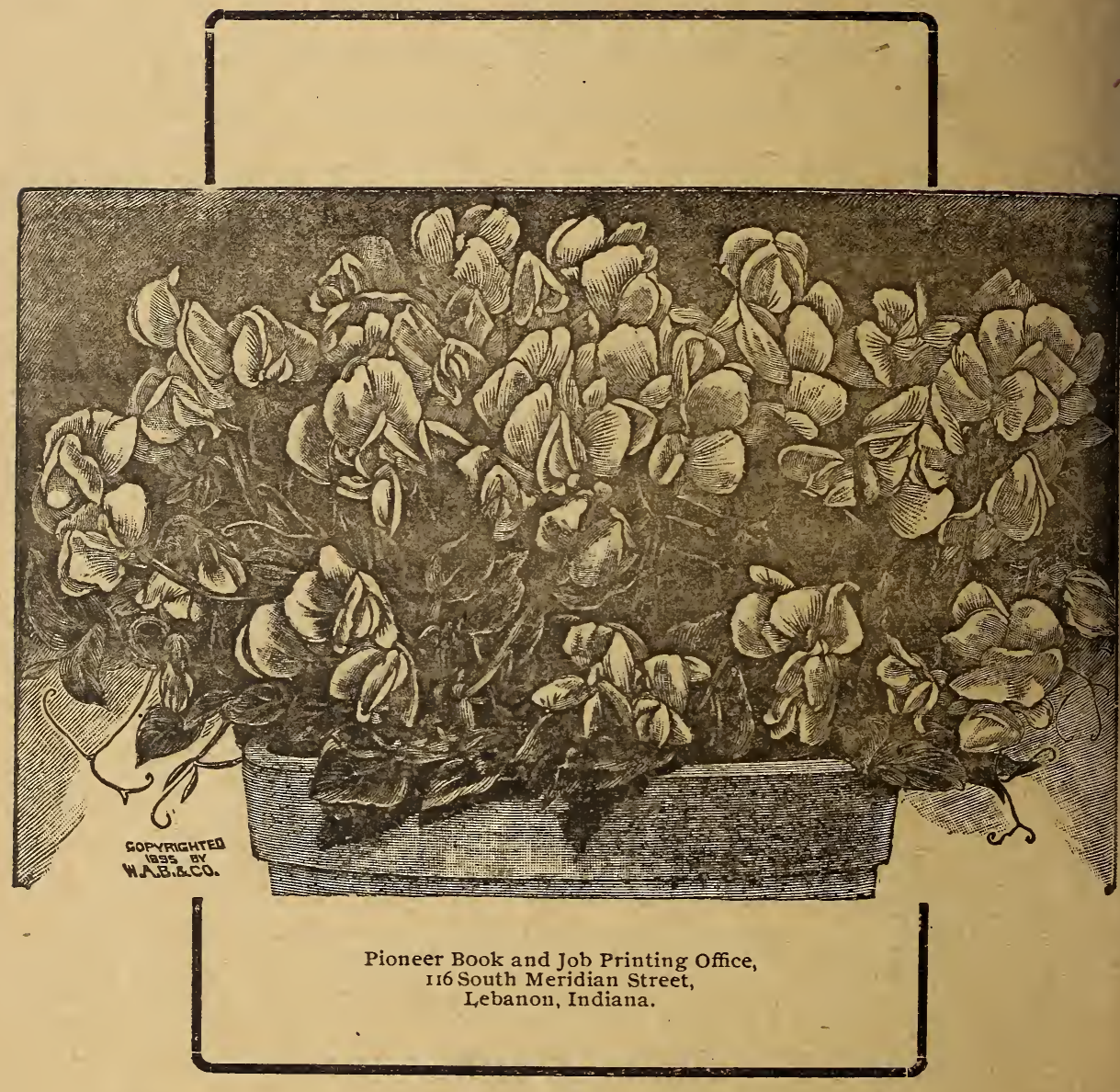

